\title{
A New Look at Licensing Basis Events for the Molten Salt Reactor Experiment
}

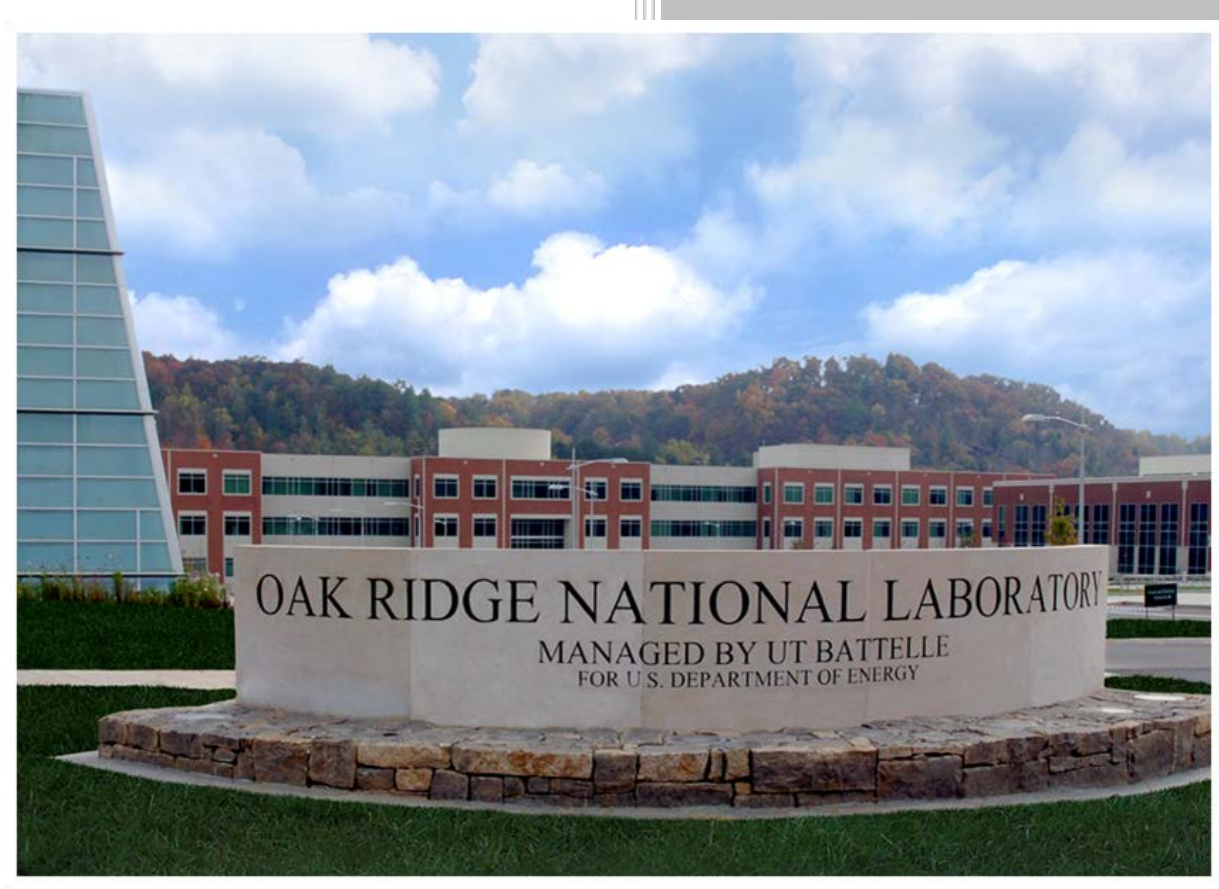

Approved for public release.

Distribution is unlimited.

Brandon M. Chisholm, Vanderbilt University George F. Flanagan Steven L. Krahn, Vanderbilt University Gary T. Mays

August 2018 


\title{
DOCUMENT AVAILABILITY
}

Reports produced after January 1, 1996, are generally available free via US Department of Energy (DOE) SciTech Connect.

\section{Website www.osti.gov}

Reports produced before January 1, 1996, may be purchased by members of the public from the following source:

\author{
National Technical Information Service \\ 5285 Port Royal Road \\ Springfield, VA 22161 \\ Telephone 703-605-6000 (1-800-553-6847) \\ TDD 703-487-4639 \\ Fax 703-605-6900 \\ E-mail info@ntis.gov \\ Website http://classic.ntis.gov/
}

Reports are available to DOE employees, DOE contractors, Energy Technology Data Exchange representatives, and International Nuclear Information System representatives from the following source:

Office of Scientific and Technical Information

PO Box 62

Oak Ridge, TN 37831

Telephone 865-576-8401

Fax 865-576-5728

E-mail reports@osti.gov

Website http://www.osti.gov/contact.html

This report was prepared as an account of work sponsored by an agency of the United States Government. Neither the United States Government nor any agency thereof, nor any of their employees, makes any warranty, express or implied, or assumes any legal liability or responsibility for the accuracy, completeness, or usefulness of any information, apparatus, product, or process disclosed, or represents that its use would not infringe privately owned rights. Reference herein to any specific commercial product, process, or service by trade name, trademark, manufacturer, or otherwise, does not necessarily constitute or imply its endorsement, recommendation, or favoring by the United States Government or any agency thereof. The views and opinions of authors expressed herein do not necessarily state or reflect those of the United States Government or any agency thereof. 
Reactor and Nuclear Systems Division

\title{
A NEW LOOK AT LICENSING BASIS EVENTS FOR THE MOLTEN SALT REACTOR EXPERIMENT
}

\author{
Brandon M. Chisholm, VU \\ George F. Flanagan \\ Steven Krahn, VU \\ Gary T. Mays
}

Date Published: August 2018

\author{
Prepared by \\ OAK RIDGE NATIONAL LABORATORY \\ Oak Ridge, TN 37831-6283 \\ managed by \\ UT-BATTELLE, LLC \\ for the \\ US DEPARTMENT OF ENERGY \\ under contract DE-AC05-00OR22725
}





\section{CONTENTS}

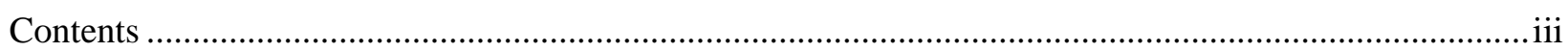

List of figures

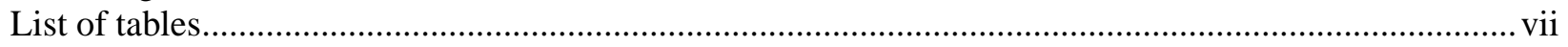

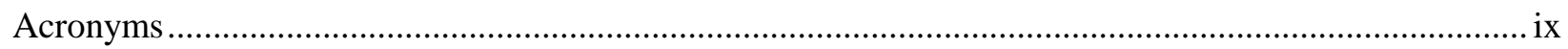

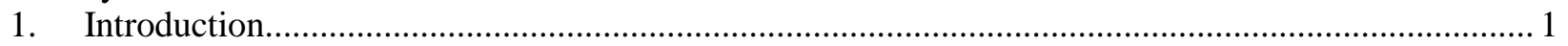

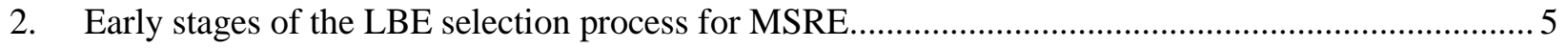

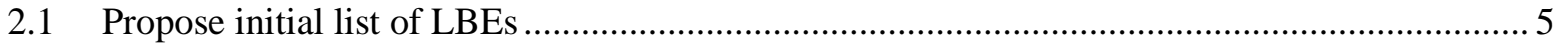

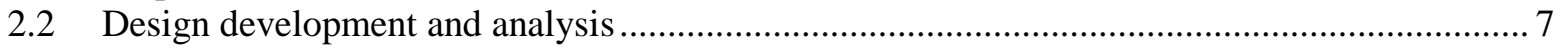

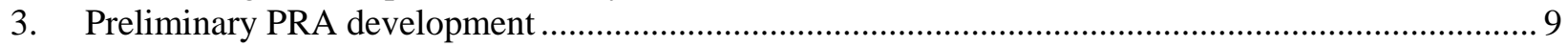

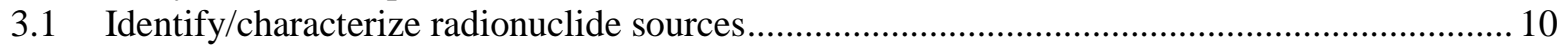

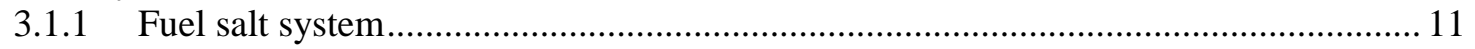

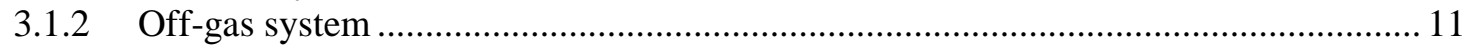

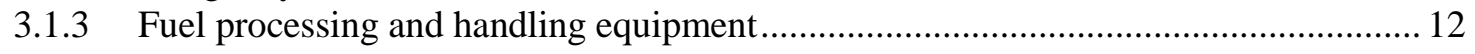

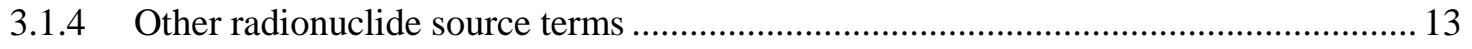

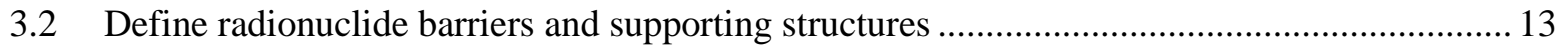

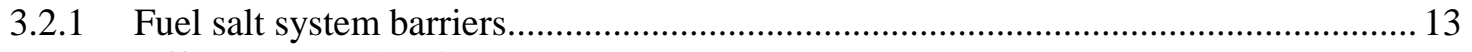

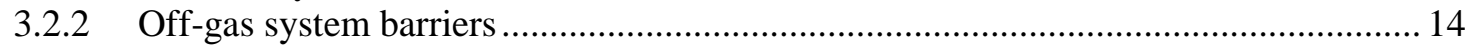

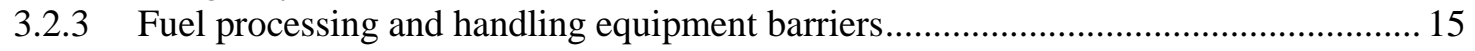

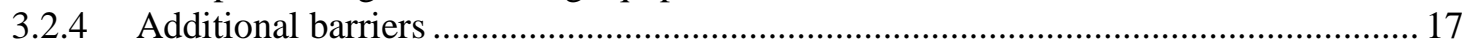

3.3 Define reactor specific safety functions protecting each barrier............................................. 17

3.4 Identify SSCs and design features supporting each safety function .................................... 19

3.4.1 Summary of MSRE safety functions and supporting SSCs/design features ................. 24

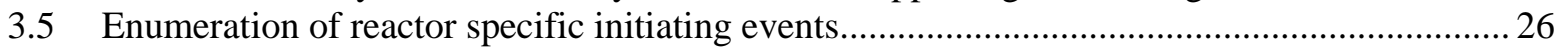

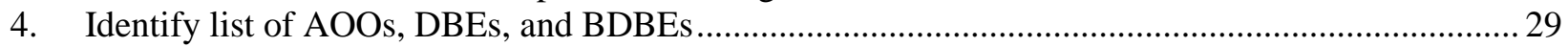

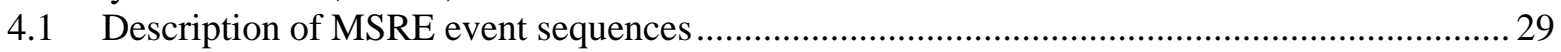

4.1.1 Inadvertent melting of FV-103 during full power operations: CCP failure .................. 29

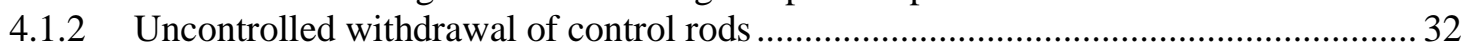

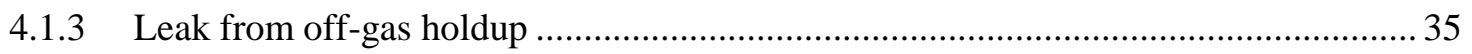

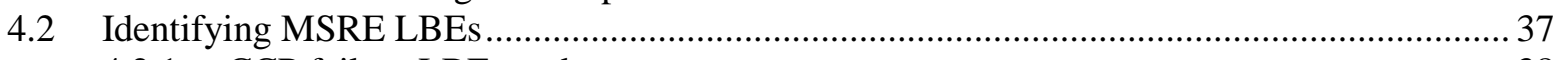

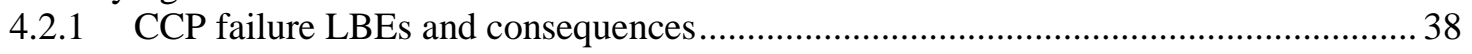

4.2.2 Uncontrolled control rod withdrawal LBEs and consequences ................................. 39

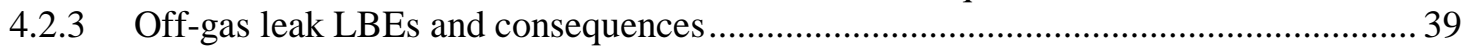

4.3 Evaluating MSRE LBEs against LMP suggested frequency vs dose curve ........................... 40

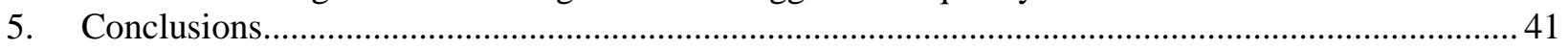

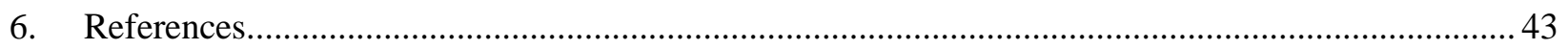

Appendix A. MSRE Fault Tree Diagrams ......................................................................................... A-2

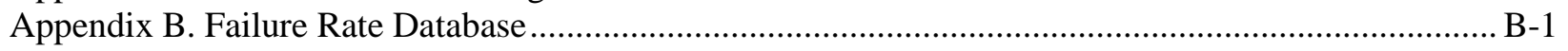

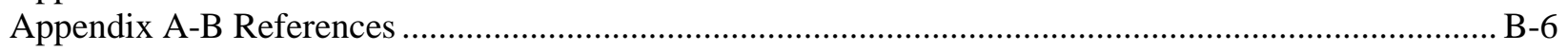





\section{LIST OF FIGURES}

Figure 1. MSRE design flowsheet [5].

Figure 2. Process for selecting and evaluating licensing basis events [2] ...................................... 6

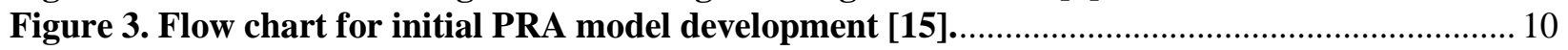

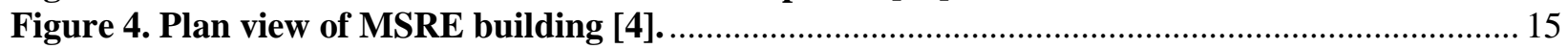

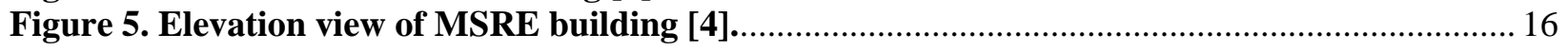

Figure 6. MSRE fuel processing system flowsheet [24] . ......................................................... 16

Figure 7. Identification of MSRE safety functions............................................................ 18

Figure 8. Temperature rise of fuel in drain tank beginning 15 min after reactor operation

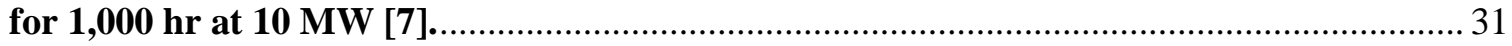

Figure 9. Event tree for failure of component cooling blower (CCP-1).......................................... 32

Figure 10. Power and temperature transients produced in the MSRE core by uncontrolled

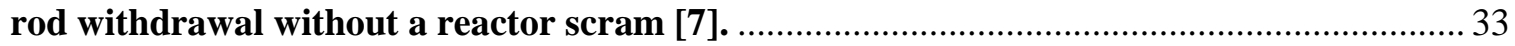

Figure 11. Event tree for uncontrolled withdrawal of control rods. ............................................. 35

Figure 12. Event tree for leak in off-gas holdup piping................................................................ 35

Figure 13. Gas systems exhausting via the MSRE stack [9] ......................................................... 37

Figure 14. Calculated frequency and consequences for MSRE LBEs compared to the frequency vs. dose curve suggested by the LMP [5]. ......................................................... 41

Figure A-1. Fault tree for failure of operating component cooling blower (CCP-1), ..................... A-2

Figure A-2. Fault tree for failure to isolate reactor cell evacuation line.......................................... A

Figure A-3. Fault tree for failure to start standby component cooling blower (CCP-2), ................ A-4

Figure A-4. Fault tree for uncontrolled control rod withdrawal............................................... A-5

Figure A-5. Fault tree for failure of afterheat removal system in Drain Tank No. 1. ................... A-6

Figure A-6. Fault tree for failure of afterheat removal system in Drain Tank No. 1 in the case of high radiation levels in the cell atmosphere................................................. A-7

Figure A-7. Fault tree for failure of afterheat removal system in Drain Tank No. 2. ................... A-8

Figure A-8. Fault tree for failure of afterheat removal system in Drain Tank No. 2 in the case of high radiation levels in the cell atmosphere. ..................................................... A-9

Figure A-9. Fault tree for failure to drain reactor............................................................ A-10

Figure A-10. Fault tree for failure to scram reactor.......................................................... A-11

Figure A-11. Fault tree for failure to transfer fuel salt between drain tanks............................. A-12

Figure A-12. Fault tree for failure of building ventilation system............................................

Figure A-13. Fault tree for failure of off-gas holdup piping .................................................. A-14 



\section{LIST OF TABLES}

Table 1. IAEA passive function categories [28].

Table 2. SSCs/design features supporting the control nuclear heat generation (reactivity)

safety function .

Table 3. SSCs and design features supporting the control chemical behavior safety function...

Table 4. SSCs and design features supporting the control heat removal and addition safety function

Table 5. SSCs and design features supporting the maintain control of radionuclides within the first barrier safety function

Table 6. SSCs and design features supporting the maintain control of radionuclides within the second barrier safety function

Table 7. Summary of frequency and consequence of analyzed MSRE LBEs 38

Table B-1. Equipment reliability data used in MSRE FTA ................................................... B-1

Table B-2. Human reliability data used in MSRE FTA B-4 



\section{ACRONYMS}

\begin{tabular}{|c|c|}
\hline ANS & American Nuclear Society \\
\hline $\mathrm{AOO}$ & anticipated operational occurrence \\
\hline ART & Aircraft Reactor Test [reactor] \\
\hline ASME & American Society of Mechanical Engineers \\
\hline BDBE & beyond design basis event \\
\hline BOP & balance of plant \\
\hline CCF & common cause failure \\
\hline СCP & component cooling pump \\
\hline CCS & component cooling system \\
\hline CFR & Code of Federal Regulations \\
\hline DBA & design basis accident \\
\hline DBE & design basis event \\
\hline DID & defense-in-depth \\
\hline DOE & US Department of Energy \\
\hline DT & drain tank \\
\hline EAB & exclusion area boundary \\
\hline ETA & event tree analysis \\
\hline FHR & fluoride salt-cooled high temperature reactor \\
\hline FMEA & failure modes and effects analysis \\
\hline FTA & fault tree analysis \\
\hline FV & freeze valve \\
\hline HAZOP & hazards and operability \\
\hline HRE & Homogenous Reactor Experiment \\
\hline HVAC & heating, ventilation, and air conditioning \\
\hline IAEA & International Atomic Energy Agency \\
\hline IE & initiating event \\
\hline LBE & licensing basis event \\
\hline LMP & Licensing Technical Requirements Modernization Project \\
\hline LWR & light water reactor \\
\hline MCA & maximum credible accident \\
\hline MHTGR & Modular High-Temperature Gas-cooled Reactor \\
\hline MSR & molten salt reactor \\
\hline MSRE & Molten Salt Reactor Experiment \\
\hline NGNP & Next Generation Nuclear Plant \\
\hline NEI & Nuclear Energy Institute \\
\hline NRC & US Nuclear Regulatory Commission \\
\hline OGS & off-gas system \\
\hline ORNL & Oak Ridge National Laboratory \\
\hline PHA & process hazards analysis \\
\hline
\end{tabular}


PRA probabilistic risk assessment

PSA probabilistic safety assessment

SDC safety design criteria

SFR

sodium fast reactor

SSC system, structures, and components 



\section{INTRODUCTION}

Southern Company and industry partners have created the Licensing Technical Requirements Modernization Project (LMP) to identify important elements of the US Nuclear Regulatory Commission (NRC) regulatory process that need to be updated or adapted to support advanced non-light water reactors (LWRs). The objectives of the LMP are to identify gaps in the regulatory process for non-LWR designs and to propose solutions based on greater use of risk-informed and/or performance-based practices on a technology-inclusive basis [1]. This project is being coordinated with the Nuclear Energy Institute (NEI) through the Advanced Reactor Working Group.

The LMP framework recognizes enhancements that can be achieved with advanced designs and safety innovations leading to reduced regulatory complexity and increased levels of safety. The project builds on best practices, previous activities implemented through the US Department of Energy (DOE), and industry-sponsored advanced reactor licensing initiatives, with a goal to provide all interested parties a timely, independent assessment of the safety and security characteristics of advanced reactor designs.

A major goal of the LMP is to outline an approach to develop a probabilistic risk assessment (PRA) for advanced non-LWR plants in support of risk-informed, performance-based applications, including:

- Evaluation of design alternatives and incorporation of risk insights into early and continuing development of the design;

- Input to the selection of licensing basis events (LBEs);

- Input to the safety classification of systems, structures, and components (SSCs);

- Selection of performance requirements for the capabilities and reliabilities of SSCs in the prevention and mitigation of anticipated transients and accidents; and

- Risk-informed and performance-based evaluation of defense-in-depth adequacy.

The LMP white paper on LBE selection [2] presents a modern, technology-inclusive, risk-informed, performance-based approach to identifying LBEs. LBEs cover a spectrum of events that are considered in the design and licensing of a nuclear power plant. A key licensing outcome of the approach outlined in the white paper is the structured selection of design basis accidents (DBAs), which are traditionally reviewed in Chapter 15 of the license application.

As the term is used in the LMP report and in this paper, LBEs are defined broadly to include all the events used to support the safety aspects of the design and to meet licensing requirements. They cover a wide range of events, from normal operation to rare, off-normal events. There are three categories of LBEs that can be addressed through PRA or alternative risk assessment methodologies ${ }^{1}$ :

- $\quad$ Anticipated operational occurrences (AOOs) encompass normal operation and planned and anticipated events with frequencies that exceed $10^{-2} /$ plant-year, from which a plant may be comprised of one or more reactor modules. The radiological doses from AOOs are required to meet normal operation public dose requirements. AOOs are used to establish operating evaluation criteria for normal operation modes and states.

- Design basis events (DBEs) encompass unplanned, off-normal events not expected in the plant's lifetime with frequencies in the range of $10^{-4}$ to $10^{-2} /$ plant-year, but which might occur in the lifetimes of a fleet of plants. The radiological doses from DBEs are required to meet

\footnotetext{
${ }^{1}$ The risk assessment methodologies used to address these events can involve either conservative approaches or best estimate approaches with appropriate accounting for uncertainties.
} 
accident public dose requirements. DBEs are the basis for the design, construction, and operation of the structures, systems, and components (SSCs) during accidents.

- $\quad$ Beyond design basis events (BDBEs) are rare off-normal events with frequencies ranging from $5 \times 10^{-7}$ /plant-year to $10^{-4}$ /plant-year. BDBEs are evaluated to ensure that they do not pose an unacceptable risk to the public, to support development of various mitigating strategies, and to provide input to the selection of DBAs.

The fourth category of LBE, assessed using deterministic approaches, is:

- Design basis accidents (DBAs ${ }^{2}$ ) are assessed using deterministic approaches. In the license application, DBAs are reviewed in Chapter 15, “Accident Analyses.” DBAs are prescriptively derived from DBEs by assuming that only safety-related SSCs are available to mitigate the consequences. The public consequences of DBAs are based on mechanistic source terms and are conservatively calculated. Alternatively, a designer may provide confidence that DBAs do not result in offsite doses by showing that fission product barriers maintain integrity, thereby preventing the release of radioactive material.

To demonstrate how the LBE selection process suggested by the LMP would be applied to an advanced reactor design, this approach was applied to the Molten Salt Reactor Experiment (MSRE), a test reactor that was designed, constructed, and operated at the Oak Ridge National Laboratory (ORNL) in the 1960s. The MSRE design was chosen for this work because (1) it is a non-proprietary MSR reference design, (2) extensive design information is available, (3) the design information includes extensive separate effects and integrated testing, and (4) information is available from five years of documented testing and operations experience. The MSRE was a single-region circulating liquid salt-fueled and cooled thermalspectrum reactor. It was capable of producing heat at a maximum rate of $7.34 \mathrm{MW}$ [3]. The fuel was $\mathrm{UF}_{4}$ in a carrier salt of $\mathrm{LiF}-\mathrm{BeF}_{2}-\mathrm{ZrF}_{4}$, and the operating temperature of the fuel salt loop averaged approximately $650^{\circ} \mathrm{C}\left(1200^{\circ} \mathrm{F}\right)$, with a hot leg temperature of about $657^{\circ} \mathrm{C}$ and a cold leg temperature of about $624^{\circ} \mathrm{C}$. The following paragraphs provide a brief description of some of the MSRE's important systems and components to facilitate a basic understanding of how the reactor was intended to operate. Fully detailed descriptions and system diagrams are available in the MSRE design and operations report [4] and the MSRE systems and components performance report [5].

Figure 1 depicts the general flowsheet of the MSRE and the major components of the system. In the fuel salt loop, the fuel salt was recirculated by a vertical short-shaft pump through the shell-and-tube heat exchanger and the reactor vessel. The heat that was generated in the fuel salt as it passed through the graphite channels of the reactor vessel was transferred in the heat exchanger to a liquid $\mathrm{LiF}_{-} \mathrm{BeF}_{2}$ coolant salt. The coolant salt was circulated by a similar centrifugal pump through the heat exchanger and a radiator. Air was blown by axial flow blowers past the radiator tubes to remove the heat; this air was then exhausted via a stack to the atmosphere.

Drain tanks stored the fuel and coolant salts when the reactor was not operating. The salts were drained to the drain tanks by gravity and were transferred back to the circulating systems by pressurizing the tanks with helium. Fission product gases were removed continuously from the circulating fuel salt by spraying a portion of the salt into the cover gas above the liquid in the fuel pump tank. From this space they were swept out by a low flow purge of helium into the off-gas system (OGS).

\footnotetext{
${ }^{2}$ Note: Within the LMP framework, DBAs are not selected on the basis of frequency, but rather by a set of prescriptive rules similar to those employed in defining DBAs for existing LWRs. DBAs often correspond to event sequences modeled in the PRA with extremely low frequencies.
} 


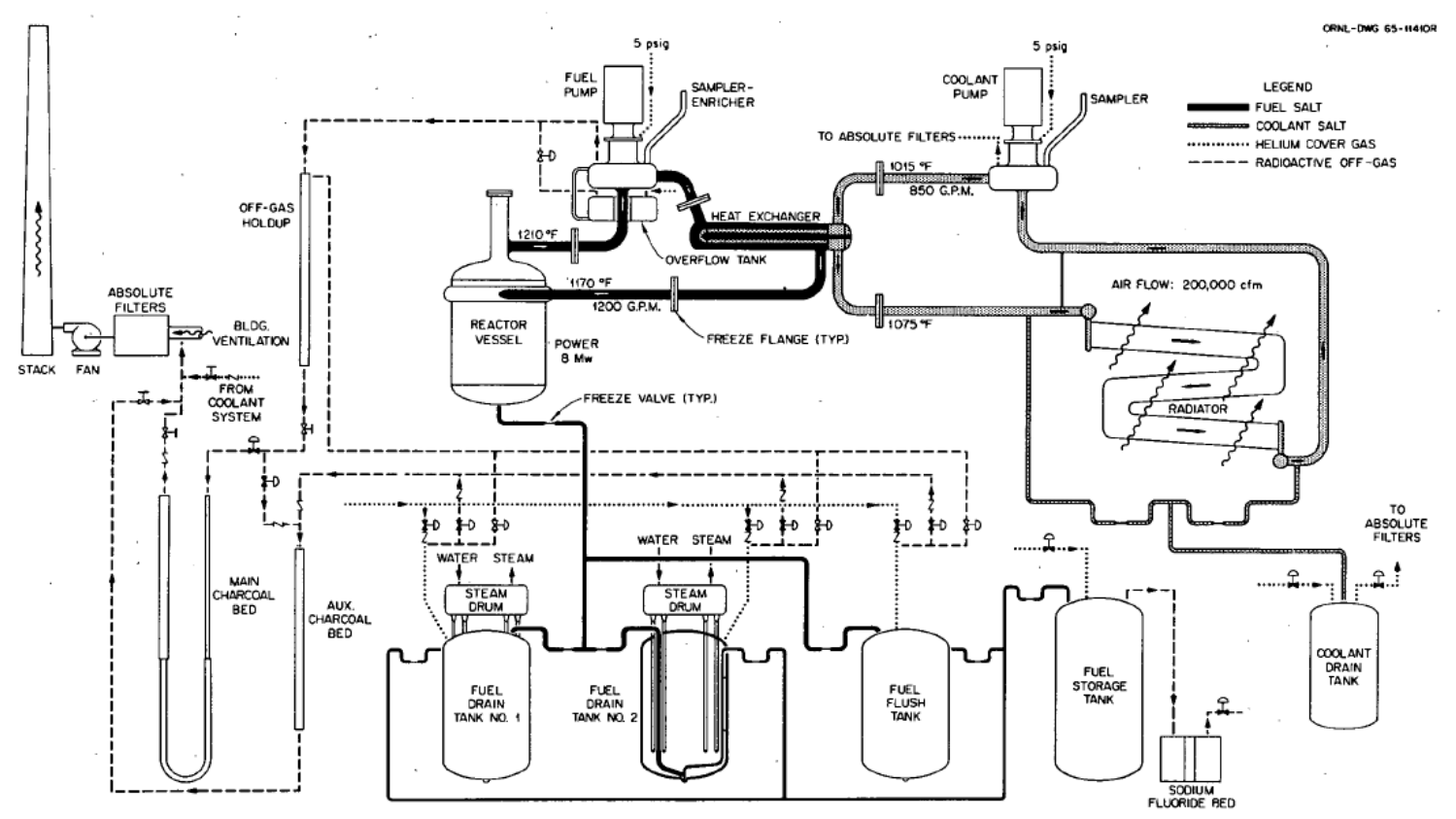

Figure 1. MSRE design flowsheet [5].

The MSRE's major auxiliary systems included the following:

1. A cover-gas system with treating stations for removing oxygen and moisture from the helium cover gas;

2. Two closed-loop oil systems for lubricating the bearings of the fuel and coolant pumps;

3. A closed loop component cooling system (CCS) for cooling in-cell components using $95 \% \mathrm{~N}_{2}$ and less than $5 \% \mathrm{O}_{2}$;

4. Several cooling water systems;

5. A ventilation system for contamination control; and

6. An instrument air system.

The plant was also provided with a simple processing facility for treating batches of fuel salt with (1) hydrogen fluoride to remove oxide contamination and (2) fluorine to remove uranium.

ORNL's MSRE designers minimized the risk of a release of radioactive material from the MSRE by providing at least two independent barriers for each component that contained or could contain multicurie amounts of radioactive material [6].

This report describes how existing MSRE hazard reports and safety analyses were used to investigate how the early steps of the process for selecting LBEs would be performed for an advanced non-LWR reactor design. Although the complete approach suggested by the LMP results in a final list of LBEs with safety related systems, subsystems, and components defined, this report simply evaluates the event sequences associated with three different initiating events (IEs). The analysis presented herein does not lead to selection of DBAs or safety-related SSCs because an exhaustive hazard analysis does not exist for MSRE and because the results of the steps performed sufficiently demonstrate the applicability of the suggested approach to this type of advanced reactor. 


\section{EARLY STAGES OF THE LBE SELECTION PROCESS FOR MSRE}

The LMP's proposed approach for selecting LBEs is detailed in a recent white paper from Southern Company [2] and is depicted in Figure 2. This section of the report describes how the early stages of the proposed LBE selection process (i.e., those that precede a PRA) were applied to the MSRE.

The analysis and application of the LMP LBE selection process to the MSRE developed in this work and discussed in the following sections of this report rely heavily on existing MSRE literature and previous hazard and safety analyses. When applying this process to a new reactor design, the maturity of the design may be such that only conceptual design information is available and little-to-no safety analysis is available. Creation of the initial list of LBEs can be aided by using hazard assessment methodologies such as a failure modes and effects analysis (FMEAs) and hazard and operability (HAZOP) studies. These methodologies identify the initial failure scenarios and support the initial PRA tasks to define IEs. Selecting the LBEs for this initial list is also aided by expert evaluation and review of the relevant experience gained from previous reactor designs and associated PRAs when available. It is imperative to ensure that information taken from other reactor technologies is interpreted correctly for the reactor technology being evaluated. Design and analysis techniques that can be applied during this stage of the design process include (1) use of traditional design bases of engineering analysis and judgment, (2) application of research and development programs, (3) use of past design and operational experience, (4) performance of design trade studies, and (5) decisions on how or whether to conform to established, applicable LWR-based reactor design criteria and whether other principle criteria are needed.

\subsection{PROPOSE INITIAL LIST OF LBES}

As illustrated in Figure 2, the first step in the LBE selection process, as suggested by the LMP, is to propose an initial list of LBEs. This initial set of LBEs can be especially relevant when developing a basic safety approach during the early stages of reactor design. This case study of the LBE selection process was performed on a design that had already been constructed and operated, so the safety approach is well documented. The hazards and accident sequences discussed in the preliminary hazards report [6] and the MSRE Safety Analysis [7] were used to develop an initial list of LBEs for the proposed design. These references provided sufficient details on some IEs and phenomena of concern for the system, as well as important MSRE safety system actions. A few important insights regarding LBEs derived from the preliminary hazards report are discussed below.

Based on the MSRE's double barrier safety approach, the authors of the "Molten Salt Reactor Experiment Preliminary Hazards Report" [6] and the "MSRE Design and Operations Report Part V: Reactor Safety Analysis Report" [7] did not evaluate accidents in which the second barrier to release was ruptured and a large fraction of the fission product activity escaped. Since these types of accidents would require two independent failures as well as a mechanism to transport this activity offsite, such accidents are deemed to be incredible. However, the report noted that the consequences from this type of scenario would be catastrophic based on studies performed for the $10 \mathrm{MW}$ Homogenous Reactor Experiment (HRE)-2 and 60 MW Aircraft Reactor Test (ART) reactors. For example, the maximum doses calculated for the release of a large fraction of the fission product activity from the ART exceeded 400 rem [8].

The preliminary hazards report discusses hazards that posed a threat to the first barrier for the fuel salt, including (1) melting of pipe/component walls due to reactivity excursion or decay heat, (2) failure from excessive stresses such as thermal or pressure, and (3) failure due to corrosion. Some IEs that were assumed to be capable of producing these hazards and that could possibly lead to a failure of this first barrier if unmitigated include [6]: 
- Operator error leading to premature criticality when filling the reactor;

- Leakage of a significant amount of water or air into the fuel salt system to precipitate $\mathrm{UO}_{2}$ from the fuel salt while it is circulating;

- Failure of the fuel salt pump and/or coolant salt pump without action by the reactor safety system;

- Sudden uncontrolled withdrawal of the control rods from the core;

- Malfunction of the drain tank afterheat removal system when hot fuel salt is drained from the core; and

- Overheating of pipe/vessel walls from electric heaters.

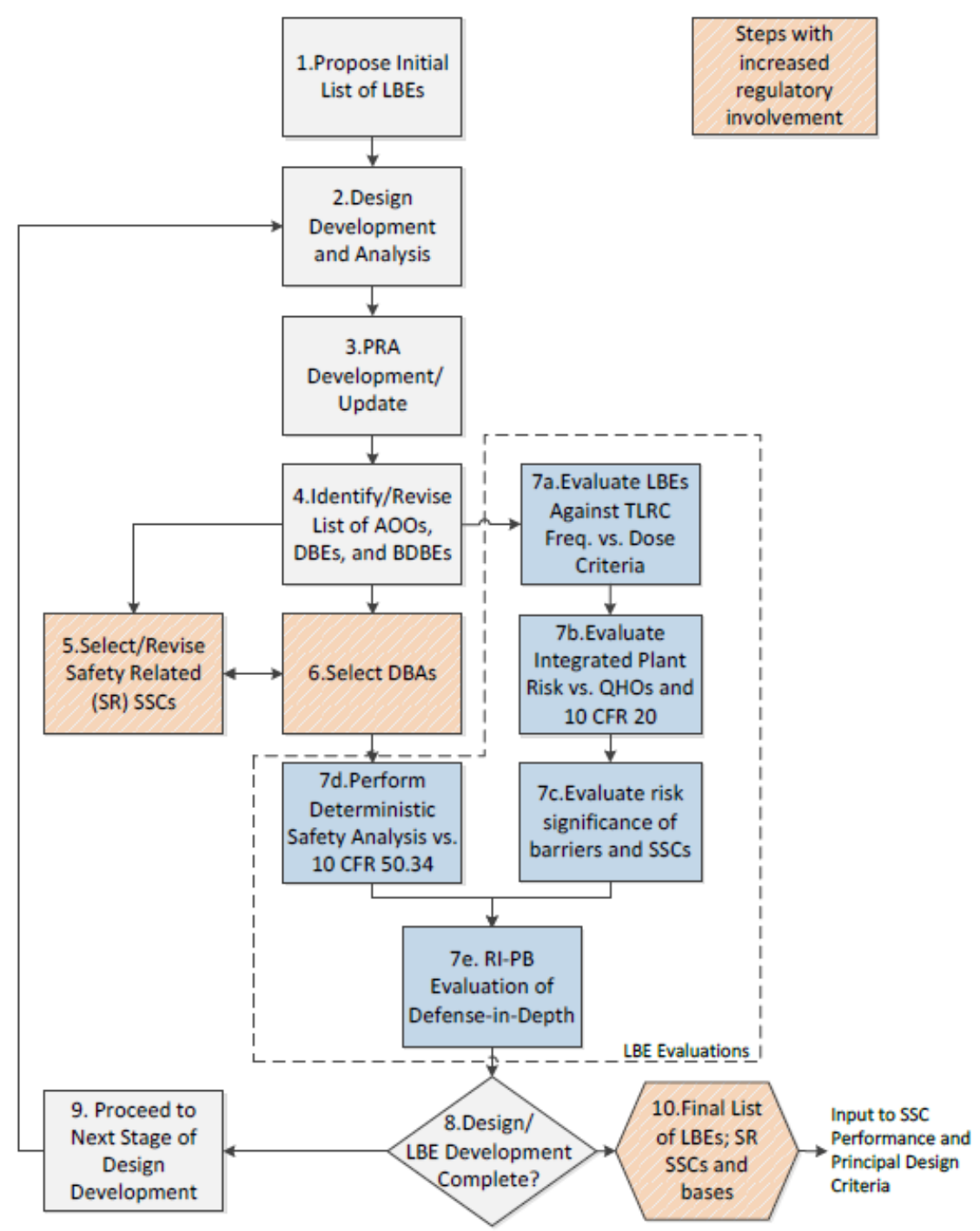

Figure 2. Process for selecting and evaluating licensing basis events [2].

Discussion in the hazards report indicates that not all the scenarios described in the preliminary hazards report represent accident sequences that require an active response by plant systems to prevent undesired consequences. This is due to several of MSRE's design features. For example, flooding of the drain cell with water when the drain tanks contained fuel salt would not produce a criticality. Even with the water acting as a neutron reflector around the drain tank, the $k_{\text {eff }}$ of the fuel salt in the tank would only increase 
from 0.826 to 0.852 . Similarly, the physical characteristics (e.g., coefficient of thermal expansion) of the fuel salt would minimize the temperature increase and thus the potential hazard to the system during some reactivity transients such as a cold fuel slug entering the core.

The hazards report discussed six conditions that presented the risk of a breach of the first barrier and thus could have posed a threat of a release through the second barrier, a seal-welded containment described in more detail in Section 3.2 of this report. ${ }^{3}$ A maximum credible accident is evaluated in the preliminary hazards report [6] and the design and operations report [7]. This accident consists of the release of fuel salt accompanied by the in-leakage of enough water to generate steam without consequent cooling. The accident is estimated to produce a peak pressure less than the test pressure of the containment. Another potential excess pressure transient described in the report is the rupture of the fuel-pump lubrication system line and subsequent ignition of the oil in the air, which contains an atmospheric concentration ( 20\%) of oxygen. ${ }^{4}$ The report concludes it is not "possible to devise a situation in which damage by missiles appeared likely," citing protection by the relatively low system operating pressure and high ductility of the structural material, as well as the steel thermal shield surrounding the reactor vessel.

While the LMP LBE selection process begins with choosing an initial set of LBEs that may not be complete, this list is necessary to guide development of the safety design approach. Existing hazard and safety analyses that were available for the MSRE made this step of the process more straightforward than it would be for the application of the LMP approach to other new non-LWR designs. In the absence of such information, the list will likely be selected deterministically based on experience gained from the design and licensing of other relevant reactor designs.

\subsection{DESIGN DEVELOPMENT AND ANALYSIS}

The next step in the LMP LBE selection process is to develop and analyze the reactor design. As previously mentioned, the scope of this work is to analyze the MSRE as designed and operated, so this step consisted of a literature review to construct a comprehensive understanding of the MSRE design and its intended operation. The major sources for understanding the system design and control strategy for the MSRE were the MSRE design and operations reports ([4], [7], [9], [10], [11], [12], [13]) and the MSRE Systems and Components Performance Report [5]. For some of the later tasks in the development of a preliminary PRA for the MSRE (including selecting IEs for accident sequences and evaluating the consequences of event sequences), the references identified in these reports serve as additional resources with more specific details on analyses performed for ORNL's MSR program.

MSRE safety systems and the inputs that would have elicited responses are described in the MSRE design and operations report on nuclear and process instrumentation [9]. ${ }^{5}$ Because this project emphasizes development of a preliminary PRA model instead of determining DBAs, and because the design/construction of the MSRE predated the Quality Assurance Criteria for Nuclear Power Plants and Fuel Reprocessing Plants (10 Code of Federal Regulations [CFR] Part 50 Appendix B) [14], the SSCs involved in MSRE safety system responses were treated no differently in this analysis than the other SSCs. In the development of quantitative models, general failure rates were applied to these components. The importance of these intended safety system responses is determined by (1) their relevance in the development of event sequences in the PRA and (2) the analysis of sequences that could lead to the potential release of radioactive material to the environment.

\footnotetext{
${ }^{3}$ Note: External events like earthquakes and floods were deemed to be incredible in the preliminary study, and sabotage is only mentioned as a possible IE.

${ }^{4}$ Under normal conditions, the oxygen content of the reactor cell is kept below 5\% by dilution with nitrogen [4].

${ }^{5}$ Table 1.5.1 and Figure 1.5.2 are especially helpful.
} 
To mitigate positive reactivity excursions, the three MSRE control rods were intended to be dropped into the reactor core (1) when a reactor period of less than +1.0 second was measured, (2) when reactor power exceeded 11.3 MW (when the fuel salt pump motor current exceeded 35 amps), or (3) when the fuel salt temperature at the reactor outlet was greater than $704^{\circ} \mathrm{C}\left(1300^{\circ} \mathrm{F}\right)$ [9]. Any of these three inputs would also initiate a sequence of valve actuations that allow the fuel salt to flow via gravity from the fuel salt loop into the drain tanks. In addition, when the control rods were scrammed, the doors of the radiator would be closed (a load scram) to rapidly reduce the heat rejection load on the system. Other inputs leading to a load scram and a reactor scram included loss of coolant salt flow ${ }^{6}$ and temperature of coolant salt at radiator outlet less than $527^{\circ} \mathrm{C}\left(980^{\circ} \mathrm{F}\right)$. Additional situations would trigger the thawing of the freeze valves (FVs) to drain the fuel salt to the drain tanks, including:

- High radioactivity in the reactor cell's atmosphere, indicating a release of radioactivity through the first barrier;

- Fuel pump overflow tank level greater than $20 \%$, indicating a high fuel salt loop inventory;

- High radioactivity in the coolant pump off-gas, indicating a leak of radioactivity from the fuel salt loop to the coolant salt loop; and

- Helium pressure in the fuel salt pump bowl greater than $172 \mathrm{kPa}$ (25 psig), indicating possible fuel salt loop overpressure.

Other actions of the MSRE safety system relevant to the preliminary PRA include:

- Closing valves in the steam dome condensate drain lines for the drain tank afterheat removal system upon high pressure or high radiation in the reactor cell; and

- Closing valves in the cell atmosphere evacuation line from the reactor cell to isolate this line from the stack exhaust flow.

The aforementioned plant responses do not constitute a comprehensive list of all safety system actions that the MSRE was intended to perform; rather, the previous discussion is provided to give examples of safety system actions pertinent to the event sequences analyzed in this work.

The next step in the LBE selection process is to define the key elements of the safety case, refining a design approach so that it meets top-level design requirements and/or developing a sufficient understanding of the design to perform a PRA. For the MSRE, the existing detailed design information was useful in highlighting the system functions and responses that were most important to the system designers. Because system design development is often performed in phases (conceptual design, preliminary design, etc.), the subsequent Tasks 3-10) of the LBE selection approach are intended to be repeated for each design iteration until the list of LBEs is finalized.

${ }^{6}$ Indicated by either flow measurement or by pump speed measurement. 


\section{PRELIMINARY PRA DEVELOPMENT}

The third step in the LMP LBE selection process (Figure 2) is to develop a PRA for the reactor system of interest. The approach suggested by LMP for developing an initial PRA is the subject of a white paper entitled "Modernization of Technical Requirements for Licensing of Advanced Non-Light Water Reactors Probabilistic Risk Assessment Approach” [15]. The approach to PRA development is represented by the flow chart in Figure 3. This section of the report describes the subtasks performed to develop a preliminary PRA for the MSRE. The PRA model will be used to obtain an order of magnitude frequency and consequence results for multiple event sequences. This information can be used in the next stage of the LBE selection process. Because the objective of this work was to demonstrate the feasibility of using the LMP LBE selection process on an MSR design, this newly developed preliminary PRA for the MSRE is not a comprehensive exploration of IEs and/or event sequences. The fault trees and event trees developed and the associated results discussed in this report all represent a portion of the much more exhaustive analysis that would be performed in the development and/or licensing of a commercial advanced non-LWR design. The event sequences were selected based on the accident analysis available in the MSRE literature [7], as well as the intent to represent IEs that would have occurred in various MSRE subsystems.

Like the PRA development approach proposed by the LMP, the preliminary PRA for the MSRE includes some simplifications from a full-scope PRA. The scope and depth of the PRA have been tailored commensurate with the availability of information, intent of the study, and with industry standards [16] [17]. For example, the analysis in this work focuses on internal IEs and includes simplified treatment of common cause failures (CCFs) and human reliability. Also, the event sequence quantification uses component reliability information from readily available engineering reports [18] [19]) and in some cases it uses reliability information for components judged to be sufficiently similar to the unique MSRE components. These estimates for failure rates should be sufficient to produce order of magnitude estimates for LBE determinations and are not intended to be as detailed as the type of analysis that would be performed for licensing purposes. Finally, in this preliminary PRA of the MSRE, the source terms are based on the best available information from the MSRE Safety Analysis Report [7], and the calculated consequences were the estimated maximum site boundary doses rather than the mean dose at the site boundary as suggested by the LMP.

The estimations of source terms and site boundary dose calculations contain significant uncertainties reflecting the state of understanding of MSRE chemistry at the time. Therefore, the behavior of fission products during the event sequences is based on the same basic assumptions made in the MSRE Safety Analysis Report [7]. Furthermore, the only accident for which a maximum site boundary dose was calculated in the report [7] was the maximum credible accident. The consequences calculated in the estimated maximum site boundary dose also included assumptions addressing other phenomena such as iodine plate out and dispersion behavior. Instead of performing new analyses, these results were carried forward in this work. 


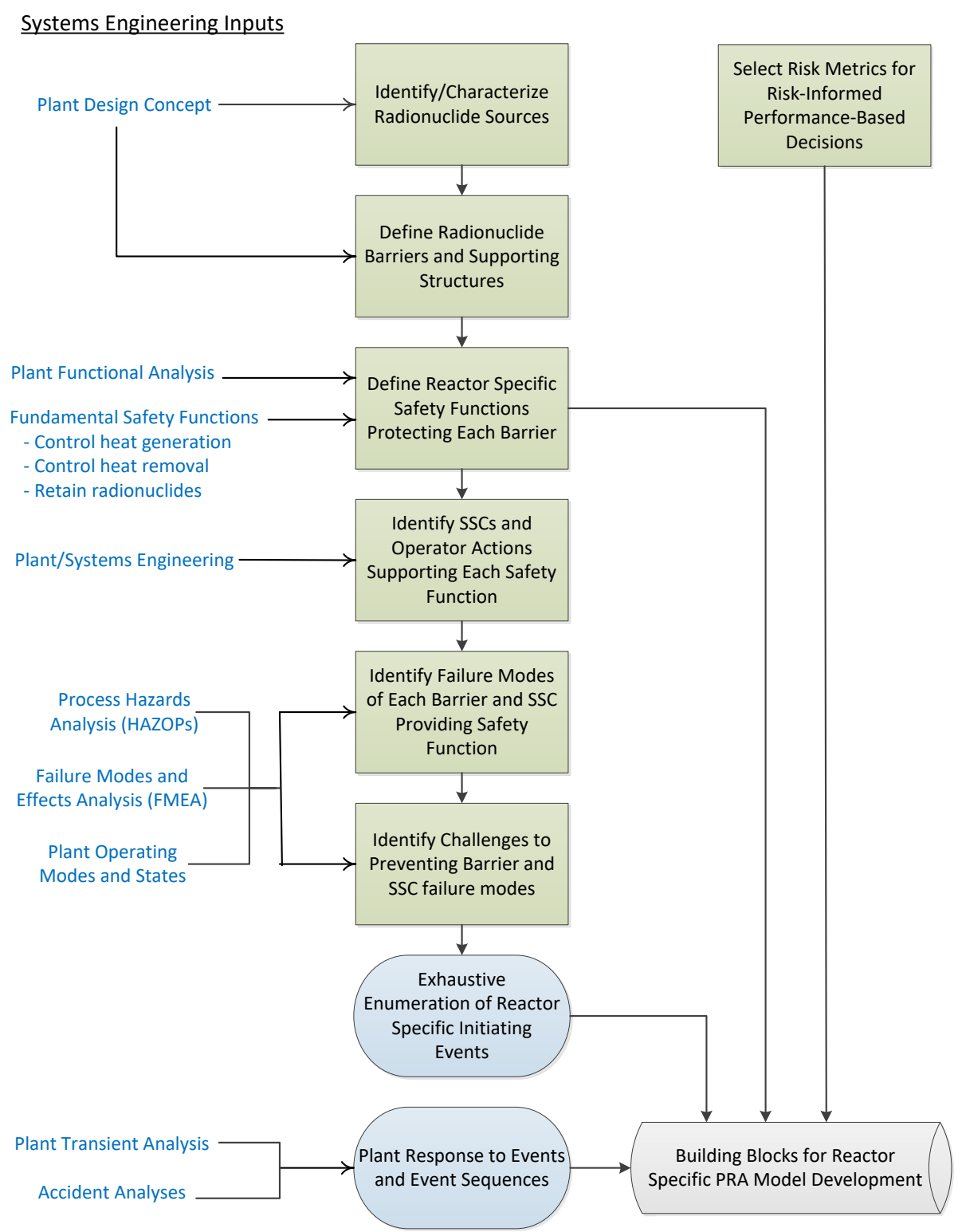

Figure 3. Flow chart for initial PRA model development [15].

\subsection{IDENTIFY/CHARACTERIZE RADIONUCLIDE SOURCES}

The LMP approach to develop a PRA model starts with identifying and characterizing the sources of radioactive material that apply to the PRA's scope. This step is particularly relevant to the analysis of a fluid-fueled MSR. During normal operation of an MSR, the radioactive isotopes and the fission products generated in the fuel are dissolved and circulating within the fuel salt loop. The volume in this salt loop is significantly larger than that of the structures confining these isotopes in other reactor designs such as fuel pellets or fuel rods. Also, due to the chemistry of the fuel salt, the fission products in the MSR system can coexist in various physical states and in various chemical compounds under normal operating conditions within the system. 
When fresh fuel salt was loaded into the MSRE, the main radioactive constituents were the various isotopes of uranium ${ }^{7}$ —or plutonium in the case of the fuel used for ${ }^{233} \mathrm{U}$ operations. ${ }^{8}$ However, during MSRE operation, fission products and activation products were generated in the fuel salt by nuclear reactions. ORNL determined that there were three principle types of fission products in the fluoride-based MSRE fuel salt. The distinguishing feature for each type of fission product is its specific mechanism of migration [20] [21]. These groups of fission products and their approximate distribution under normal operating conditions (in weight percent [22]) are as follows:

1. Salt seekers (e.g., Sr, Y, Zr, I, Cs, Ba, Ce): 59 wt\%, soluble in fuel salt and remain with the fuel salt in inventory amounts

2. Noble metals (e.g., $\mathrm{Nb}, \mathrm{Mo}, \mathrm{Ru}, \mathrm{Sb}, \mathrm{Te}$ ): $24 \mathrm{wt} \%$, reduced by the $\mathrm{UF}_{3}$ in the fuel salt and exist in salt in the metallic state. Because of their incompatibility with salt, they migrate to various surfaces - including graphite, Hastelloy N, and gas-liquid interfaces - and adhere to them.

3. Noble gases ( $\mathrm{Kr}$ and $\mathrm{Xe}$ ): $17 \mathrm{wt} \%$, slightly soluble gases in the fluid fuel, and as such, they may be readily stripped from the fuel.

One aspect that could complicate the tracking of these fission products throughout the MSRE system was that certain fission products would transition between groups according to their respective decay paths. For example, ${ }^{137} \mathrm{Xe}$ was stripped out of the fuel salt as a noble gas, so a significant amount of ${ }^{137} \mathrm{Cs}$ (a daughter product of ${ }^{137} \mathrm{Xe}$ ) could be found in the off-gas system rather than in the fuel salt, even though ${ }^{137} \mathrm{Cs}$ is considered a salt seeker.

According to the preliminary hazards report, approximately 1,850 PBq (50 million curies) of radioactivity were contained within the MSRE building at any given time during operations [6]. For the purposes of the development of the preliminary PRA in this report, three major radionuclide sources were considered to exist, and each had a defined set of barriers between the source and the environment.

\subsubsection{Fuel salt system}

The MSRE's largest and most obvious source of radioactive material was the fuel salt. Under normal operation, the fuel salt was pumped through the reactor core, the primary heat exchanger, and the associated piping by the fuel salt pump. All of these components were located in the reactor cell of the MSRE building. The component that separated this material from the drain tanks (in the drain tank cell) was a FV in the connecting drain/fill line. Upon shutdown or initiation of a fuel salt drain by one of the safety systems, the frozen salt plug in the FV was melted, and the fuel salt drained via gravity into at least one if not both of the drain tanks in the drain tank cell. Calculations performed after the conclusion of MSRE operations [23] using the ORIGEN isotope generation and depletion code resulted in an estimate of around 1,055 PBq (28.5 million curies) in the fuel salt upon final shutdown, with $981 \mathrm{PBq}$ (26.5 million $\mathrm{Ci}$ ) coming from fission products in the fuel salt, and the remaining approximately $74 \mathrm{PBq}$ (2 million $\mathrm{Ci}$ ) coming from transuranics. ${ }^{9}$

\subsubsection{Off-gas system}

The next major source of radionuclides during normal operation of the MSRE was the collection of volatile fission products, mostly the noble gases $\mathrm{Kr}$ and Xe. Some concentration of these isotopes would

\footnotetext{
${ }^{7}$ e.g.,. $~ 185 \mathrm{GBq}$ (5 curies) of ${ }^{234} \mathrm{U}[23]$

${ }^{8}$ e.g.,. $\sim 6 \mathrm{TBq}$ (160 curies) of ${ }^{241} \mathrm{Pu}$ and $\sim 1.7 \mathrm{TBq}$ (46 curies) of ${ }^{239} \mathrm{Pu}$ [23]. The plutonium was artificially added by the MSRE team during ${ }^{233} \mathrm{U}$ operations in order to investigate the performance of fuel salts with different compositions and nuclear and physical performance characteristics.

${ }^{9}$ Calculations in the MSRE safety analysis [7] assumed that the total radioactivity of the entire fuel salt was about 10 million curies during normal operation.
} 
exist dissolved in the fuel salt under normal conditions, but the introduction of helium into the fuel salt in the bowl of the fuel salt pump by the cover gas system was intended to strip a significant portion of these noble gases from the fuel salt (assumed to be 38\% [23]). As fuel salt was sprayed out of holes in a distributor in the pump bowl, the noble gases vented from the salt and were drawn into a pipe running from the gas space of the fuel salt pump bowl to the off-gas system [4]. The off-gas system included a piping run to provide hold-up time for the radioactive gases to decay ( $\sim$ two hours), water-cooled beds of activated charcoal to adsorb Xe, roughing filters and particle filters to retain $99.9 \%$ of particles greater

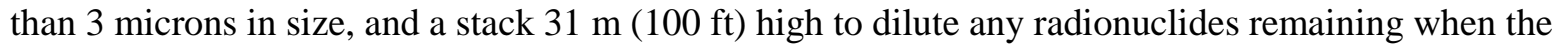
resulting effluent was exhausted to the atmosphere.

This radioactive gas (mixed with helium carrier gas) in the off-gas system was estimated to remove about $10.5 \mathrm{TBq}$ (280 curies) each second from the pump bowl into the off-gas line [4]. In the charcoal beds, the residence time of Xe was designed to be at least 90 days, and the residence time for $\mathrm{Kr}$ was at least 7.5 days. During this time, almost all of the fission product gases decayed to stable elements. However, because some of the daughters in the decay chains of the fission produce gases were solids (e.g., ${ }^{89} \mathrm{Sr}$, ${ }^{137} \mathrm{Cs},{ }^{140} \mathrm{Ba}$ ), deposits in the charcoal beds, filters, and piping retained these daughters. By the time that the gas left the charcoal bed, the only radioactive isotopes that existed in any significant amount were ${ }^{85} \mathrm{Kr},{ }^{131 \mathrm{~m}} \mathrm{Xe}$, and ${ }^{133} \mathrm{Xe}[4]$.

\subsubsection{Fuel processing and handling equipment}

The final major radioactive source at the MSRE was the fuel processing and handling equipment in the fuel processing cell and adjacent adsorber cubicle. It is important to note that because the MSRE did not perform online fuel salt processing, fuel salt would not have been in the fuel salt system and the fuel processing system at the same time. Although the radionuclides entered the fuel processing cell in the form of fuel salt, the fuel processing equipment could be classified as a distinct source term for two reasons. First, the fuel processing and handling equipment contained barriers that are notably different than those discussed for the previous two sources. Although the fuel salt storage tank was similar in construction to the drain tanks, during processing of the fuel salt, the first barrier preventing the release of radioactive material was composed of components that were not used anywhere else in the MSRE system (i.e., NaF bed, NaF traps, caustic scrubber). Furthermore, the second barrier between the radioactive material in the fuel processing equipment was a separate cell that could fail independently of the reactor and drain cells. The other factor that differentiated the fuel processing equipment as a separate source was the composition, form, and radioactivity of the fuel salt in the fuel processing equipment. Before processing began, the fuel salt in the fuel salt storage tank was slightly different than the fuel salt when it was under normal conditions in the fuel salt loop, and the fuel salt composition after fluorination was notably distinct from the fuel salt anywhere else in the MSRE system.

- The fuel salt was allowed to decay in the drain tank for at least 10 days after operation before it was transferred to the fuel salt storage tank. This was to prevent an excessive release of Xe when beginning to purge the gas space in the fuel processing equipment. After the decay period, the decay rate of Xe would be equal to the production rate [24], and the overall radioactivity of the fuel salt would be notably lower than it was when it was circulating in the fuel salt loop. ORIGEN calculations indicate a reduction from 1,055 PBq (28.5 million Ci) to $167 \mathrm{PBq}$ (4.5 million $\mathrm{Ci}$ ) after a decay period of 3 days [23].

- When the fuel salt in the storage tank was treated with a mixture of $\mathrm{HF}$ and $\mathrm{H}_{2}$ for the removal of oxides, volatilization of corrosion or fission products was not significant [24]. However, during fluorination (for recovery of $U$ ), many elements were volatilized out of the fuel salt. During the fluorination, almost all of the $\mathrm{H}, \mathrm{He}, \mathrm{Se}, \mathrm{Br}, \mathrm{Kr}, \mathrm{Nb}, \mathrm{Mo}, \mathrm{Tc}, \mathrm{Ru}, \mathrm{Te}, \mathrm{I}, \mathrm{Xe}, \mathrm{U}$, and Np were separated from the fuel, with most of these isotopes being retained in the $399^{\circ} \mathrm{C}\left(750^{\circ} \mathrm{F}\right) \mathrm{NaF}$ bed or the $93^{\circ} \mathrm{C}\left(200^{\circ} \mathrm{F}\right) \mathrm{NaF}$ absorbers downstream of the fuel storage tank. Thus, the salt remaining 
in the storage tank after uranium recovery, the off-gas from the fluorination process (including the volatilized $\mathrm{UF}_{6}$ ), and the deposits on the $\mathrm{NaF}$ bed and absorbers were all forms of radioactive material that were not present anywhere else in the MSRE system. ${ }^{10}$

\subsubsection{Other radionuclide source terms}

The three sources described above represent a significant majority of the total radioactivity that was in the MSRE plant during normal operations. However, several other sources of radioactive material could be considered distinct from the sources discussed above. For example, another source of radioactivity in the MSRE was tritium. Around $2 \mathrm{TBq}$ (55 curies) of tritium were produced in the MSRE per day, mainly due to neutron interactions with the $\mathrm{Li}$ in the fuel salt), with about half of this tritium carried off in the off-gas of the fuel salt, 5-10\% diffusing to both the cooling air across the radiator and to the reactor cell atmosphere, and 15 percent absorbed into the core graphite [25]. At any given point, there also may have been some amount of radioactivity contained in the liquid waste system in the liquid waste storage tank filters or the associated piping and pumps). However, little information about estimated radiation levels in these components was found in the available MSRE documentation, and quantification would require new analyses. Additional sources of radioactivity in the reactor cell included the startup source and any fission, corrosion, or activation products that were plated out on or absorbed into components with sustained contact with fuel salt. Consideration of these sources would likely be necessary, especially in analysis for maintenance evolutions and decommissioning. However, due to lack of information on the form and amount of radioactive material and the minimal contribution to site boundary doses during event sequences, these minor sources were not considered for the development of the MSRE preliminary PRA in this work.

\subsection{DEFINE RADIONUCLIDE BARRIERS AND SUPPORTING STRUCTURES}

The next task in developing the MSRE preliminary PRA was to define the radionuclide barriers for each source. As previously mentioned, the MSRE was designed and operated so that any component containing multi-curie levels of radioactive material included at least two barriers between the radioactivity and the environment [6]. The following paragraphs discuss the first and second barriers for each of the three major sources identified in the previous section: the fuel salt, the off-gas system, and the fuel processing and handling equipment.

\subsubsection{Fuel salt system barriers}

For the first major source of radioactive material — the fuel salt - the first ${ }^{11}$ barrier ${ }^{12}$ preventing release was the physical integrity of the fuel salt loop and the drain tanks. During normal operation, the fuel salt was circulated through the reactor vessel, the fuel salt pump, and the shell side of the heat exchanger. The

\footnotetext{
${ }^{10}$ Another source that must be considered consider when developing a full MSR PRA is any used fuel salt that might be stored on site, especially if it is stored in a frozen state. While halide salts are virtually immune to radiation damage when they are molten, gamma radiolysis of solid salt results in the formation and liberation of molecular fluorine [41] [42]. This molecular fluorine can act in a manner similar to fluorine gas during fluorination, volatilizing uranium and fission products. Because experience has shown that this process can result in the unexpected transport of radionuclides outside of storage [43], this radioactive source must be addressed when exhaustively considering all source terms in an MSR.

${ }^{11}$ In this report, the barriers to release are referred to as "first" and "second" to avoid confusion with "primary" and "secondary" systems.

${ }^{12}$ The term "barrier" in this report is used consistently with its usage in the MSRE Design and Operations Reports (e.g. [4]), which could more accurately be described as a "physical barrier." When considering the entirety of the safety case of MSRE, it is possible to think of the fuel salt itself as the first barrier to the release of fission products. Similar to the IAEA's consideration of the fuel matrix as the first barrier confining fission products in an LWR [44] (even though it is prone to cracking), the fuel salt does retain some, but not all, fission products [45] [46].
} 
fuel salt was prevented from draining to the drain tanks by a frozen plug of salt inside an FV in the drain line at the bottom of the core. Other parts of this first barrier included the fuel salt piping, the freeze flanges in the piping, and the fuel salt pump expansion tank. ${ }^{13}$ If the frozen salt plug in the FV of the drain line were to melt, then the salt would have an unobstructed path to Fuel Drain Tanks 1 and 2, as the reactor was operated with the additional two FVs that isolated the drain tanks from the drain line in the thawed condition. Thus, the drain line, the fuel salt drain tanks, and the transfer piping to the FVs (which were deep frozen) also constituted part of the first barrier for the fuel salt.

The second barrier preventing release of the fuel salt was a seal-welded containment vessel which housed all of the components containing fuel salt. Although the schematics in Figure 4 and Figure 5 indicated that the reactor cell and drain tank cell were located in separate vessels, an interconnection between the two cells allowed for air to pass from one cell to the other, so in effect, they operated as one cell [4][5]. This containment was maintained at a slight vacuum $(87.6 \mathrm{kPa},-2 \mathrm{psig})$ by the gas blower in the component cooling system to prevent outflow of airborne radioactivity/contamination in case it was present in either cell [4]. The cell atmosphere was $\mathrm{N}_{2}$, and it contained less than $5 \% \mathrm{O}_{2}$ to reduce the probability of fires or explosions that could be caused by leakage of oil from the fuel salt's circulating pump lubricating system. The allowable leakage from the reactor and drain tank cells was assumed to be $1 \%$ of the cell volume per day at $275.8 \mathrm{kPa}$ (40 psig); these are the conditions encountered in the postulated maximum credible accident [4]. This assumed leak rate was based on (1) sealing and inspection of these seals to reduce the gas leakage at the piping and wire penetrations through the cell walls and (2) hydrostatically testing of the containment vessels prior to operation to $331 \mathrm{kPa}$ (48 psig), and subsequently holding the cells at $138 \mathrm{kPa}$ (20 psig) for 20 hours. This test resulted in a leakage rate of $0.25 \%$ per day [7].

\subsubsection{Off-gas system barriers}

The first barrier preventing release of the fuel salt contained penetrations, some of which connected the fuel salt system to the system(s) for handling and disposal of the second major source of radionuclides: the fuel salt off-gas. The helium cover gas used to strip noble fission product gases out of the fuel salt was drawn out of the pump bowl. Both drain tanks had off-gas piping that allowed for radioactive gases to flow through the off-gas disposal system. Components constituting the first barrier for the off-gas source also included the particle filter trap, the off-gas holdup pipe, the main charcoal bed, and the auxiliary charcoal bed. During normal operation, proper functioning of the filters_-along with the amount of time it would take the gas stream to reach the exit of the charcoal beds-were sufficient factors to reduce the radioactivity of the off-gas to levels low enough that the gas could be exhausted out of the stack with a diluting airflow. However, in the case of high radiation levels in the lines after the outlet of the charcoal beds, the safety system of the MSRE closed valves in the line to prevent the release of high levels of radiation to the environment. It is important to note that, in this scenario, these valves in the offgas line downstream of the charcoal beds served as a single barrier between the radioactivity in the offgas disposal system and the MSRE stack, which vented to the atmosphere.

The second barrier for the off-gas source term was slightly different than that for either of the other two major radionuclide sources because it was composed of several different smaller structures in different locations around the MSRE building. The off-gas line from the reactor pump bowl started in the reactor cell, which also contained the off-gas holdup pipe. However, after the holdup pipe, the off-gas line continued through the reactor cell wall penetration and through the coolant salt areas encased in a 3/4-inch

\footnotetext{
${ }^{13}$ Although the sampler-enricher penetrates the first and second barriers of the fuel salt system to provide access to the pump bowl, the component is designed in such a way that there are at least two independent barriers preventing the release of radioactive material even during operation of the component to collect a sample from the pump [4]. The sampler-enricher also has off-gas piping that interfaces with the off-gas system; however, because the sampler-enricher was only in operation during specific tests, it is not considered further in this work.
} 
pipe surrounded by $\sim 10 \mathrm{~cm}$ of lead shielding. The line then passed through valves in a pressure-tight instrument box located in the lower portion of the vent house. From this box, the line continued in an underground shielded duct to an underground valve box and then to the charcoal bed cell, which had cooling water flowing through the cell. As discussed previously, after the gas flow exited the charcoal beds, it was primarily made up of helium carrier gas. This mostly clean gas flowed to an underground valve box and then to a filter pit before mixing with air and being drawn through the absolute filters of the ventilation system to be discharged from the stack 33.5 meters (110 feet) south of the MSRE building.

\subsubsection{Fuel processing and handling equipment barriers}

Figure 6 displays the major components and general flow paths for the fuel processing system of the MSRE, the third major radionuclide source. During fuel processing, the FVs in the transfer lines to the fuel salt drain tank were frozen, and the salt sampler contained at least two independent barriers preventing the release of radioactive material. This design is similar to that of the fuel salt samplerenricher (see footnote 13 above) [24]. As discussed in Section 3.1.3, little radioactivity was volatilized during $\mathrm{H}_{2}-\mathrm{HF}$ treatment for oxide removal: during this process, most of the radioactive material was either in the fuel storage tank or in the NaF bed. During uranium recovery, fission, corrosion, and activation products were volatilized. Therefore, the first barrier preventing release for this radioactive source term included the fuel storage tank, the $\mathrm{NaF}$ bed, the NaF absorbers, the caustic scrubber, the activated charcoal trap, and the absolute filter.

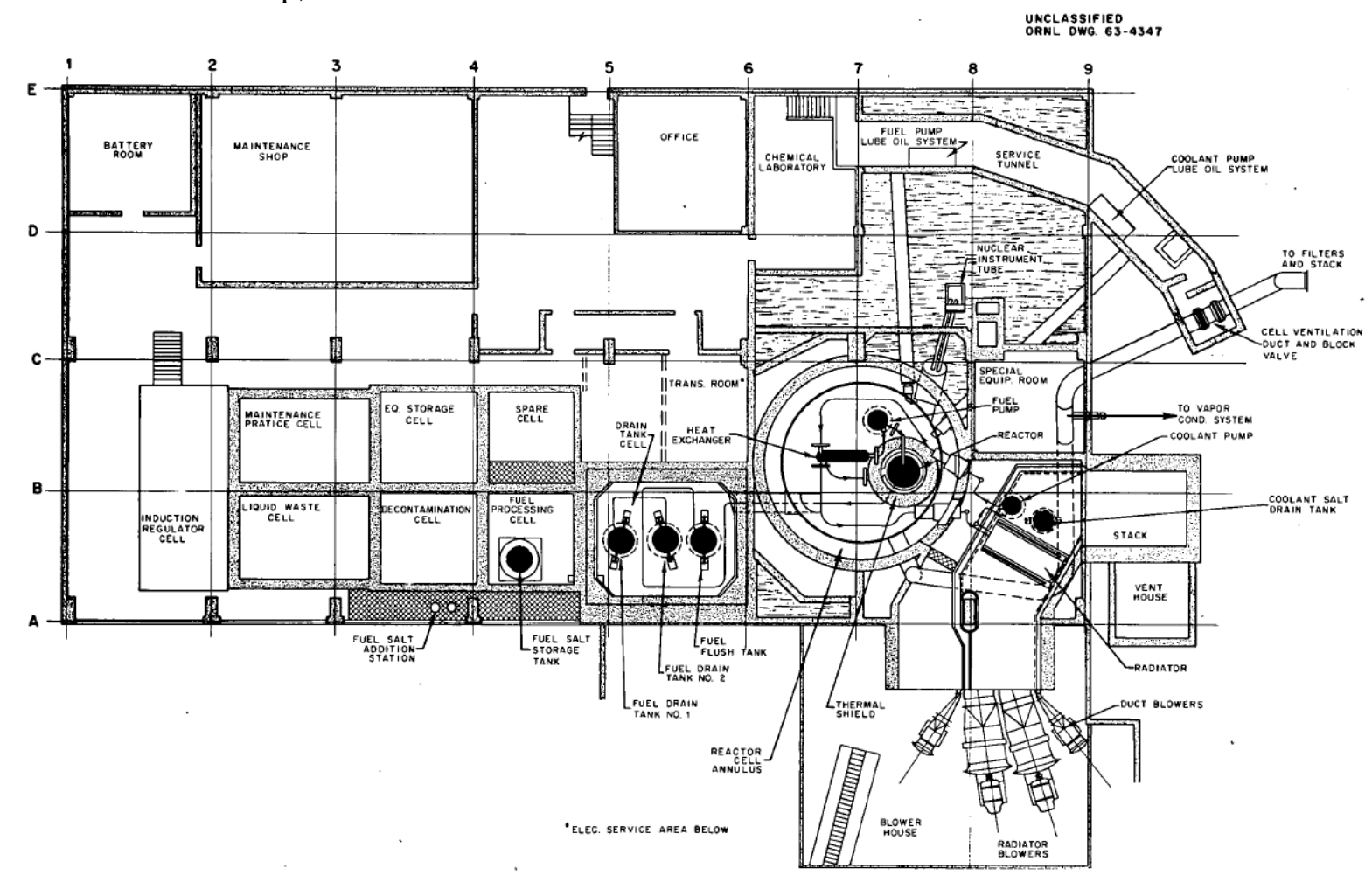

Figure 4. Plan view of MSRE building [4]. 


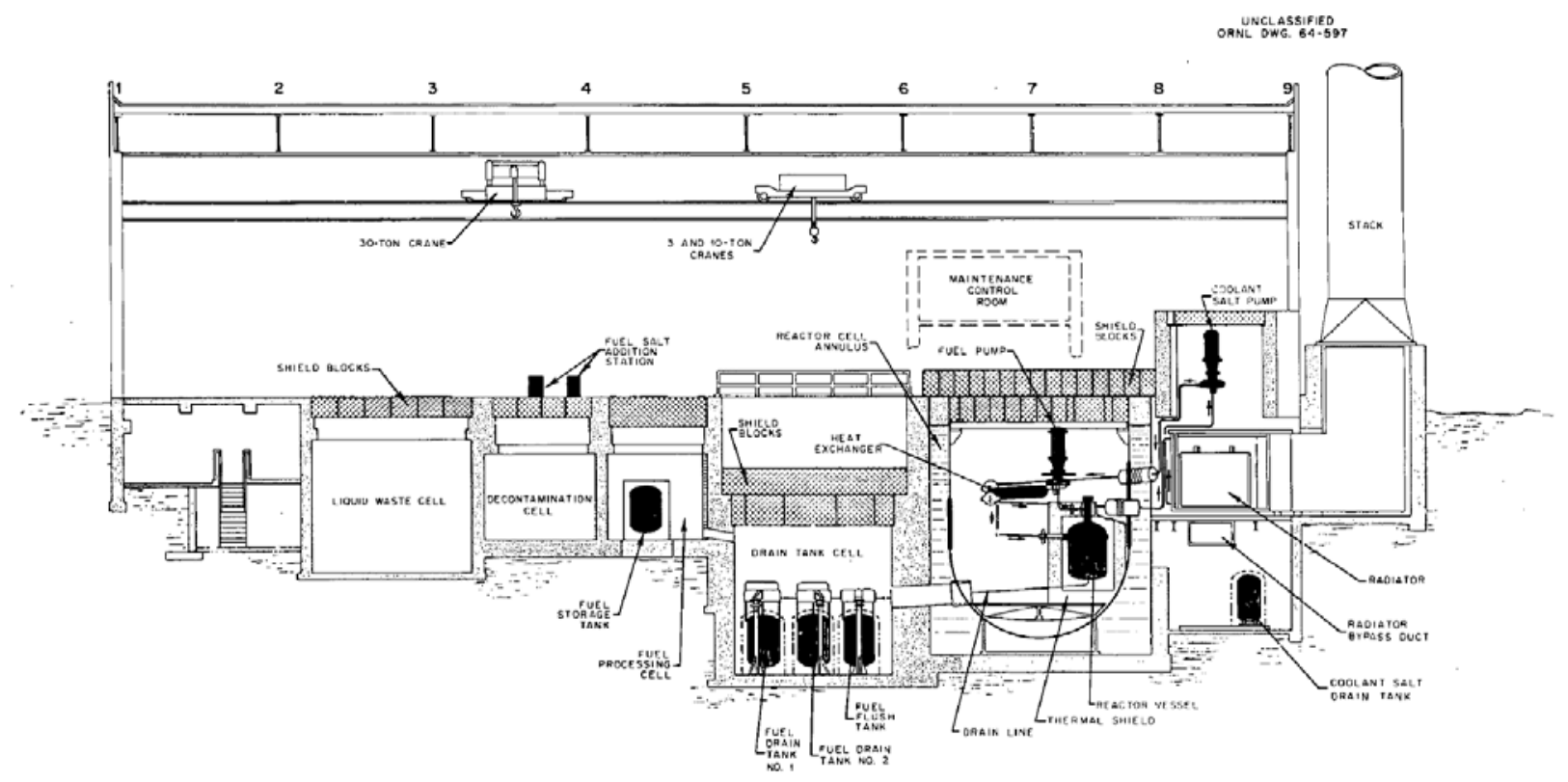

Figure 5. Elevation view of MSRE building [4].

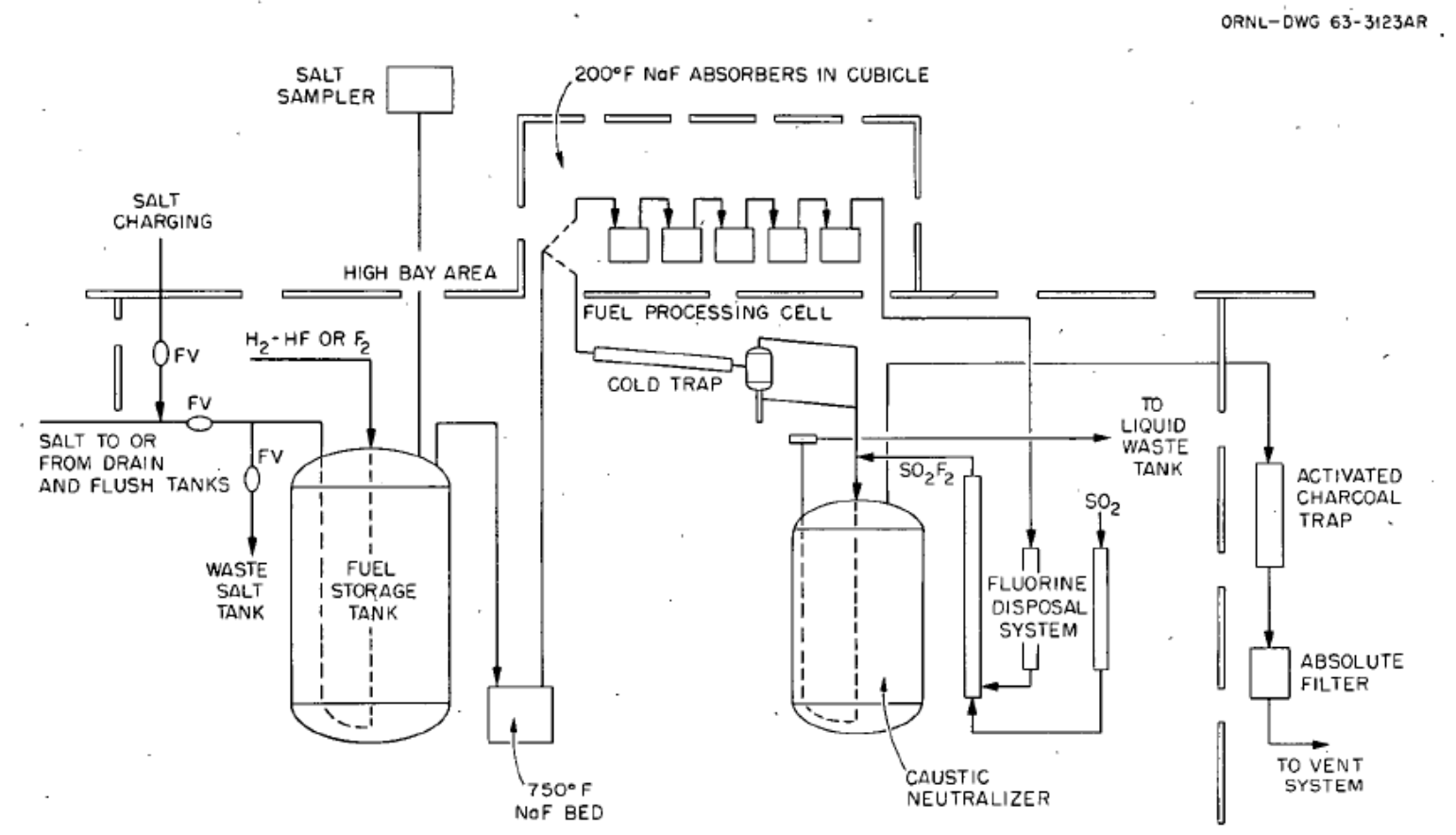

Figure 6. MSRE fuel processing system flowsheet [24].

The second barrier preventing release for the fuel processing equipment was similar to the barrier for the fuel salt. The main portion of the fuel handling and processing system was in the fuel processing cell, in which all penetrations were tightly sealed, and a negative was pressure maintained during processing [24]. The off-gas filter, hydrogen flame arrester, activated charcoal trap, and waste salt removal line were located in the spare cell adjacent to the fuel-processing cell. The NaF absorbers used for retaining $\mathrm{UF}_{6}$ were contained in a cubicle with the same containment features described for the reactor and fuel 
processing cells, including being maintained at negative pressure during processing using a dedicated blower.

\subsubsection{Additional barriers}

Two additional features of the MSRE building that contributed to its ability to mitigate the release of radioactivity were the vapor condensing system and the containment ventilation system. The vapor condensing system was designed to prevent the pressure in the reactor cell from exceeding the maximum allowable pressure of $276 \mathrm{kPa}$ (40 psig) in the scenario of the maximum credible accident. This accident resulted in the production of a significant amount of steam. The containment ventilation system used one of two centrifugal fans (also referred to as the stack fans) at the base of the MSRE stack to induce air flow through the various containment areas in and adjacent to the MSRE building before the air flow passed through absolute filters and was monitored for radioactivity before release. If radioactive particles reached the air in the high bay area, the filters were designed to prevent the release of this activity through the stack. Although the MSRE Design and Operations Report describes the ventilation system as a third barrier to the release of radioactivity [4], there was no mechanism to prevent or mitigate the release of volatile radioactive species. While potential solids or liquids would likely be captured, the present analysis indicates that the containment ventilation was simply a function to support containment.

\subsection{DEFINE REACTOR SPECIFIC SAFETY FUNCTIONS PROTECTING EACH BARRIER}

In the approach advocated in the LMP white paper and discussed in the PRA Standard for Advanced Non-LWR Nuclear Power Plants [16], the next information to be developed for a PRA of an advanced non-LWR is a list of safety functions to protect each radionuclide barrier. In this report, the term safety function is defined as a "function that must be performed to control the sources of energy in the plant and radiation hazards, and to maintain integrity of one or more barriers to release of radioactive material including the fuel barrier, reactor coolant pressure boundary, and containment, confinement, or reactor building barrier(s)." This definition is consistent with the definition in the Advanced Non-LWR PRA Standard [16]. The specific safety functions ${ }^{14}$ unique to the MSRE are likely applicable to other MSRs. For this analysis, they were derived from high-level, technology-neutral safety functions for fission reactors. The safety functions specified herein are based on experience to date with other reactor types that have an approach similar to that used in the "Fluoride-Salt-Cooled, High-Temperature Reactor (FHR) Subsystems Definition, Functional Requirement Definition, and Licensing Basis Event (LBE) Identification White Paper" [26]. Starting from the most basic level according to the International Atomic Energy Agency (IAEA) [27], the three fundamental safety functions of nuclear reactors are as follows:

1. Control heat generation

2. Control heat removal

3. Retain radionuclides

The unique details of the specific reactor design require some tailoring of relevant safety functions specifically for the MSRE, as shown in Figure 7. This tree-shaped logic diagram was developed through functional analysis and describes the hierarchy of a specific objective-maintain control of radioactive release - and the associated MSRE functions. An example of this logical process to elicit the reactor's technology-specific functions can be seen in the PRA developed for the Modular High Temperature GasCooled Reactor (MHTGR) [28].

\footnotetext{
${ }^{14}$ In a safety analysis performed consistent with NUREG-0800 requirements, some of these safety functions may be classified as required safety functions if they are necessary or relied upon in the DBA to meet the criteria for the analysis, or they may be classified as supportive safety functions if they are not necessary to meet the Chapter 15 safety analysis criteria but still play a role in mitigating and/or preventing an accident. In other references, these functions may be called principal design criteria, toplevel safety functions, or safety design criteria [26] [39] [40].
} 
As the diagram shows, two high-level objectives must be achieved to control the impact of radionuclide release: control the radiation release, and control personnel access to the source terms. This risk assessment work focuses on potential risks to offsite members of the public that are assumed to be at the plant's exclusion area boundary (EAB).

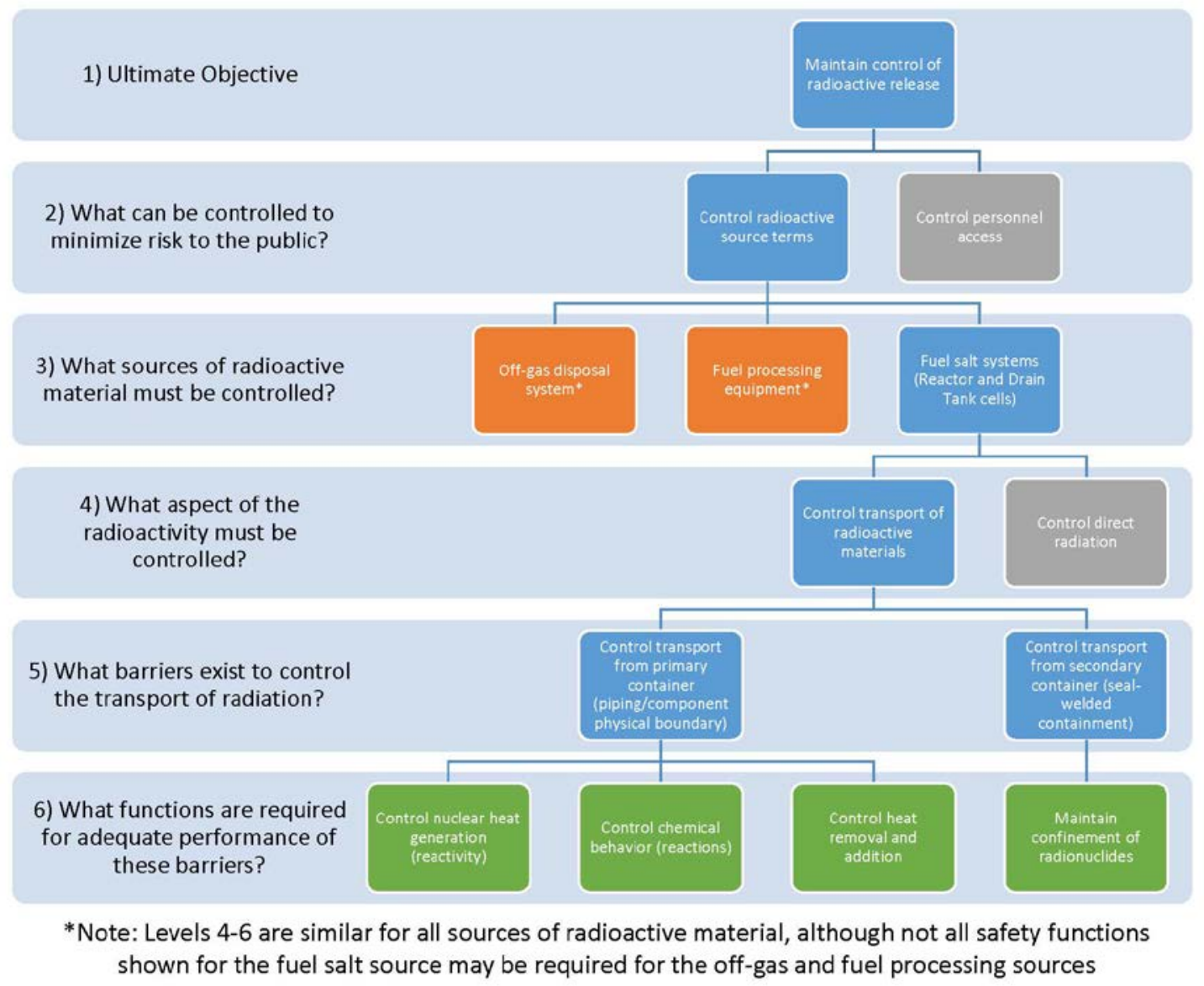

Figure 7. Identification of MSRE safety functions.

The next level (Level 3) of the diagram identifies the major radioactive source terms that must be controlled in the plant, as identified in Section 3.1. Although it has been noted that a non-negligible amount of activity was located within the off-gas disposal system or in the fuel processing equipment during fuel processing, the safety functions required to control the radioactivity in these subsystems were consistent with some of those required to control the radioactivity in the fuel salt system. The SSC or design feature achieving a given safety function may depend on the source/type of the radioactive material; however, no safety functions are presently identified for these other two sources that are not needed for the fuel salt inventory of radiological material. ${ }^{15}$

\footnotetext{
${ }^{15}$ The results in this work are presented with the caveat that the understanding of safety functions required for controlling the radioactive source in the off-gas disposal system and/or in the fuel processing equipment must be expanded further as the risk assessment work progresses and that future work is required to confirm that the risks from all radioactive source terms are acceptably low.
} 
The fourth level of the diagram identifies that control of radiation hazards from the fuel salt system involved addressing both direct radiation (i.e., shielding for gamma and neutron radiation), as well as controlling the release of radioactive material from the fuel salt system. The offsite public was protected from the former hazard by distance from the source and shielding provided by the MSRE building and structure. As was maintained for the Modular High-Temperature Gas-Cooled Reactor (MHTGR) PRA, any threat that could remove this protection was considered remote [28]. Therefore, this risk assessment focused on events that affected the possibility of radioactivity release from the MSRE building to the environment, although any future consideration of occupational risks must account for direct radiation consequences.

The fifth level of the diagram in Figure 7 indicates that a radioactive material release from the fuel salt systems must occur by the failure of two barriers. Therefore, it is necessary to (1) control release through the first barrier and (2) control release through the second barrier. As discussed in Section 3.2, these barriers (and to some extent, the associated functions on the sixth level) were identified using the MSRE Preliminary Hazards Report [6] and the MSRE Design and Operations Reports.

The sixth and final level of the Figure 7 diagram shows the four safety functions tailored for use in the MSRE analysis. Based on the results of the functional analysis displayed in Figure 7—combined with a review of the safety functions determined for the PRISM reactor [15], the MHTGR [28] and FHRs [26]the MSRE design-specific safety functions are:

- Control heat generation (reactivity)

- Control heat removal and addition

- Control chemical behavior

- Maintain control of radionuclides

0 within the first boundary

o within the second boundary

These safety functions can be used to provide a preliminary definition of the functional grouping of IEs by the nature of the challenge presented to safety functions and they are used herein for development the preliminary PRA model ${ }^{16}$ [15]. Each of the safety functions listed above that support a given functionalong with the SSCs and design features of the MSRE mentioned in the MSRE Preliminary Hazards Report [6] or the MSRE Design and Operations Report [7]—are discussed in Section 3.4 of this report.

\subsection{IDENTIFY SSCS AND DESIGN FEATURES SUPPORTING EACH SAFETY FUNCTION}

Tables 2-6 list the MSRE's active SSCs, design features, and passive SSCs. These SSCs and design features are grouped according to the safety function that they support or for which they provide defensein-depth (DID). These tables were developed by (1) surveying the MSRE literature, (2) creating a list of the hazards and event sequences discussed, (3) identifying the associated MSRE safety function(s) that were intended to mitigate each hazard, and (4) documenting any other SSCs and features explicitly mentioned to play a role in the plant response to the hazard. ${ }^{17}$ The passive SSCs are further classified based on the IAEA passive function categories [29] similar to the PRISM safety functions summarized in [15]. These passive function categories are defined in Table 1.

\footnotetext{
${ }^{16}$ Final definition of the functional grouping of IEs would be subject to verification after the completion of a comprehensive process hazard analysis (PHA) [16]. No such review has been done to date for the MSRE.

${ }^{17}$ The process of developing this information in a comprehensive manner (and/or without the availability of prior hazards analyses) could be comprehensively performed through the use of an industry-standard PHA methodology, such as a hazards and operability (HAZOP) study [47].]
} 
Table 1. IAEA passive function categories [29]

\begin{tabular}{|c|c|c|}
\hline Category & Characteristics & Examples \\
\hline $\mathrm{A}$ & $\begin{array}{l}\text { No signal inputs of "intelligence" } \\
\text { No external power sources or forces } \\
\text { No moving mechanical parts } \\
\text { No moving working fluid }\end{array}$ & $\begin{array}{l}\text { Nuclear fuel cladding } \\
\text { Primary coolant boundary } \\
\text { Inherent reactivity feedback }\end{array}$ \\
\hline B & $\begin{array}{l}\text { No signal inputs of "intelligence" } \\
\text { No external power sources or forces } \\
\text { No moving mechanical parts } \\
\text { Moving working fluids }\end{array}$ & $\begin{array}{l}\text { Containment cooing systems based on } \\
\text { natural circulation of air flowing } \\
\text { around the containment walls }\end{array}$ \\
\hline $\mathrm{C}$ & $\begin{array}{l}\text { No signal inputs of "intelligence" } \\
\text { No external power sources or forces } \\
\text { Moving mechanical parts } \\
\text { Whether or not moving working fluids are also present }\end{array}$ & $\begin{array}{l}\text { Overpressure protection and/or } \\
\text { emergency cooling devices of pressure } \\
\text { boundary systems based on fluid } \\
\text { release through relief valves }\end{array}$ \\
\hline $\mathrm{D}$ & $\begin{array}{l}\text { Contain inputs, mechanical parts and working fluid, } \\
\text { but meet the following criteria: (1) energy must only } \\
\text { be obtained from stored sources such as batteries or } \\
\text { compressed or elevated fluids; (2) active components } \\
\text { are limited to controls instrumentation and valves } \\
\text { (single-action relying on stored energy); (3) manual } \\
\text { initiation is excluded }\end{array}$ & $\begin{array}{l}\text { Emergency core cooling systems based } \\
\text { on gravity-driven flow of coolant, } \\
\text { activated by valves which break open } \\
\text { on demand }\end{array}$ \\
\hline
\end{tabular}

Table 2. SSCs/design features supporting the control nuclear heat generation (reactivity) safety function SSC/design feature Active/passive/design feature

\begin{tabular}{|c|c|c|}
\hline & teature & term(s) \\
\hline Low excess reactivity in reactor & Passive (A) & $\begin{array}{l}\otimes \text { Fuel salt } \\
\square \text { Fuel processing } \\
\square \text { Off-gas }\end{array}$ \\
\hline $\begin{array}{l}\text { Negative temperature coefficient } \\
\text { (high salt thermal expansion) }\end{array}$ & Passive (A) & $\begin{array}{l}\bigotimes \text { Fuel salt } \\
\square \text { Fuel processing } \\
\square \text { Off-gas }\end{array}$ \\
\hline $\begin{array}{l}\text { FV for draining located in close proximity to reactor core } \\
\text { vessel to allow valve to melt by residual heat in case of } \\
\text { loss of power }\end{array}$ & Design feature & $\begin{array}{l}\bigotimes \text { Fuel salt } \\
\square \text { Fuel processing } \\
\square \text { Off-gas } \\
\end{array}$ \\
\hline $\begin{array}{l}\text { Drain tank geometry: fourfold concentration increase } \\
\text { required for criticality in drain tanks (salt freezing } \\
\text { increases concentration by only threefold), as flooding } \\
\text { drain tank cell does not produce criticality }\end{array}$ & Design feature & $\begin{array}{l}\bigotimes \text { Fuel salt } \\
\square \text { Fuel processing } \\
\square \text { Off-gas }\end{array}$ \\
\hline $\begin{array}{l}\text { Gradual stoppage of pump and exponential decay of } \\
\text { neutron precursors, limiting reactivity effect in core due } \\
\text { to loss of fuel salt flow }\end{array}$ & Passive (C) & $\begin{array}{l}\bigotimes \text { Fuel salt } \\
\square \text { Fuel processing } \\
\square \text { Off-gas }\end{array}$ \\
\hline $\begin{array}{l}\text { Due to operation in thermal spectrum, additional } \\
\text { reflection needed for criticality outside the core }\end{array}$ & Design feature & $\begin{array}{l}\bigotimes \text { Fuel salt } \\
\bigotimes \text { Fuel processing } \\
\square \text { Off-gas }\end{array}$ \\
\hline $\begin{array}{l}\text { Automatic insertion of poison by control system upon } \\
\text { high neutron flux }\end{array}$ & Active & $\begin{array}{l}\bigotimes \text { Fuel salt } \\
\square \text { Fuel processing } \\
\square \text { Off-gas }\end{array}$ \\
\hline $\begin{array}{l}\text { Ability to drain fuel salt to drain tank using heater to melt } \\
\text { FV }\end{array}$ & Active & $\begin{array}{l}\bigotimes \text { Fuel salt } \\
\square \text { Fuel processing } \\
\square \text { Off-gas }\end{array}$ \\
\hline
\end{tabular}


Table 3. SSCs and design features supporting the control chemical behavior safety function

\begin{tabular}{|c|c|c|}
\hline SSC/design feature & $\begin{array}{c}\text { Active/passive/design } \\
\text { feature }\end{array}$ & $\begin{array}{c}\text { Applicable source } \\
\text { term(s) }\end{array}$ \\
\hline $\begin{array}{l}\text { Zirconium fluoride in fuel salt provides margin against } \\
\text { precipitation of } \mathrm{UO}_{2} \text { from contamination by air and } \\
\text { moisture }\end{array}$ & Design feature & $\begin{array}{l}\otimes \text { Fuel salt } \\
\bigotimes \text { Fuel processing } \\
\square \text { Off-gas } \\
\end{array}$ \\
\hline $\begin{array}{l}\text { Salt does not wet graphite (radiation effects do not } \\
\text { change this behavior) }\end{array}$ & Design feature & $\begin{array}{l}\bigotimes \text { Fuel salt } \\
\square \text { Fuel processing } \\
\square \text { Off-gas }\end{array}$ \\
\hline $\begin{array}{l}\text { Charcoal bed cell is filled with water to suppress the risk } \\
\text { of fire }\end{array}$ & Design feature & $\begin{array}{l}\square \text { Fuel salt } \\
\square \text { Fuel processing } \\
\text { 囚 Off-gas }\end{array}$ \\
\hline $\begin{array}{l}\text { Blanket of } \mathrm{CO}_{2} \text { resulting from a fire in charcoal beds } \\
\text { would extinguish fire }\end{array}$ & Passive (B) & $\begin{array}{l}\square \text { Fuel salt } \\
\square \text { Fuel processing } \\
\text { 囚 Off-gas } \\
\end{array}$ \\
\hline $\begin{array}{l}\text { Helium purified (oxygen and moisture removed) before } \\
\text { being supplied as cover gas }\end{array}$ & Active & $\begin{array}{l}\text { 囚 Fuel salt } \\
\text { 囚 Fuel processing } \\
\text { 囚 Off-gas } \\
\end{array}$ \\
\hline $\begin{array}{l}\text { Purging gas system of nitrogen to maintain atmosphere } \\
\text { content less than } 5 \% \text { oxygen in reactor and drain } \\
\text { tank cells }\end{array}$ & Active & $\begin{array}{l}\bigotimes \text { Fuel salt } \\
\square \text { Fuel processing } \\
\square \text { Off-gas }\end{array}$ \\
\hline $\begin{array}{l}\text { Inlet and exit valves can be closed on charcoal bed in the } \\
\text { event of a fire }\end{array}$ & Active & $\begin{array}{l}\square \text { Fuel salt } \\
\square \text { Fuel processing } \\
\text { 囚 Off-gas }\end{array}$ \\
\hline
\end{tabular}

Table 4. SSCs and design features supporting the control heat removal and addition safety function

\begin{tabular}{|c|c|c|}
\hline SSC/design feature & $\begin{array}{c}\text { Active/passive/design } \\
\text { feature }\end{array}$ & $\begin{array}{c}\text { Applicable source } \\
\text { term(s) }\end{array}$ \\
\hline $\begin{array}{l}\text { Once fuel salt is drained to the drain tank, drain tank } \\
\text { cooling system is capable of removing } \sim 100 \mathrm{kw} \text { of heat } \\
\text { with } 6 \text { hours' worth of emergency water on site }\end{array}$ & Design feature & $\begin{array}{l}\bigotimes \text { Fuel salt } \\
\square \text { Fuel processing } \\
\square \text { Off-gas }\end{array}$ \\
\hline $\begin{array}{l}\text { Heat exchanger and all piping pitch downward to } \\
\text { promote drainage of salt to the vessel and then to the } \\
\text { drain tank }\end{array}$ & Design feature & $\begin{array}{l}\otimes \text { Fuel salt } \\
\square \text { Fuel processing } \\
\square \text { Off-gas }\end{array}$ \\
\hline $\begin{array}{l}\text { Even with no cooling medium, heating in the core } \\
\text { graphite due to entrapped fission product decay results in } \\
\text { a temperature increase of less than } 38^{\circ} \mathrm{C}\left(100^{\circ} \mathrm{F}\right) \text { in } 48 \\
\text { hours }\end{array}$ & Design feature & $\begin{array}{l}\bigotimes \text { Fuel salt } \\
\square \text { Fuel processing } \\
\square \text { Off-gas }\end{array}$ \\
\hline $\begin{array}{l}\text { About } 10 \text { seconds are required for the pump motor to } \\
\text { stop after electrical supply is interrupted }\end{array}$ & Passive (C) & $\begin{array}{l}\bigotimes \text { Fuel salt } \\
\square \text { Fuel processing } \\
\square \text { Off-gas }\end{array}$ \\
\hline $\begin{array}{l}\text { Thermal insulation around the piping allows the system } \\
\text { to retain heat to prevent salt from freezing in lines }\end{array}$ & Passive (A) & $\begin{array}{l}\otimes \text { Fuel salt } \\
\square \text { Fuel processing } \\
\square \text { Off-gas }\end{array}$ \\
\hline
\end{tabular}


Table 4. SSCs and design features supporting the control heat removal and addition safety function (continued)

\begin{tabular}{|c|c|c|}
\hline SSC/design feature & $\begin{array}{c}\text { Active/passive/design } \\
\text { feature }\end{array}$ & $\begin{array}{c}\begin{array}{c}\text { Applicable source } \\
\text { term(s) }\end{array} \\
\end{array}$ \\
\hline $\begin{array}{l}\text { Pneumatic valves for controlling drain tank cooling water } \\
\text { fail to open position }\end{array}$ & Passive (D) & $\begin{array}{l}\otimes \text { Fuel salt } \\
\square \text { Fuel processing } \\
\square \text { Off-gas }\end{array}$ \\
\hline $\begin{array}{l}\text { Natural circulation of salt systems is capable of removing } \\
\text { afterheat if the fuel salt is not drained to the drain tank }\end{array}$ & Passive (C) & $\begin{array}{l}\bigotimes \text { Fuel salt } \\
\square \text { Fuel processing } \\
\square \text { Off-gas }\end{array}$ \\
\hline $\begin{array}{l}\text { Fuel salt loop cooling occurs via the heat exchanger; the } \\
\text { heat-to-coolant loop is then discharged to the atmosphere } \\
\text { via a radiator with use of radiator fans }\end{array}$ & Active & $\begin{array}{l}\bigotimes \text { Fuel salt } \\
\square \text { Fuel processing } \\
\square \text { Off-gas }\end{array}$ \\
\hline $\begin{array}{l}\text { Thermal shield cooling system around reactor core vessel } \\
\text { is capable of removing } 600 \mathrm{kw} \text { of heat }\end{array}$ & Active & $\begin{array}{l}\bigotimes \text { Fuel salt } \\
\square \text { Fuel processing } \\
\square \text { Off-gas }\end{array}$ \\
\hline Thermal mass of water in thermal shield & Passive (A) & $\begin{array}{l}\bigotimes \text { Fuel salt } \\
\square \text { Fuel processing } \\
\square \text { Off-gas }\end{array}$ \\
\hline $\begin{array}{l}\text { Emergency diesel electric power supply is available for } \\
\text { pumps following loss of power }\end{array}$ & Active & $\begin{array}{l}\bigotimes \text { Fuel salt } \\
\square \text { Fuel processing } \\
\square \text { Off-gas }\end{array}$ \\
\hline $\begin{array}{l}\text { Pipeline heaters and a furnace prevent salt from freezing } \\
\text { in lines }\end{array}$ & Active & $\begin{array}{l}\bigotimes \text { Fuel salt } \\
\bigotimes \text { Fuel processing } \\
\square \text { Off-gas }\end{array}$ \\
\hline $\begin{array}{l}\text { Heaters can be turned on to reduce heat transfer from the } \\
\text { radiator }\end{array}$ & Active & $\begin{array}{l}\bigotimes \text { Fuel salt } \\
\square \text { Fuel processing } \\
\square \text { Off-gas }\end{array}$ \\
\hline $\begin{array}{l}\text { The charcoal beds are submerged in water to remove } \\
\text { decay heat from the off-gas; each of the two parallel beds } \\
\text { is capable of handling the entire off-gas load }\end{array}$ & Active & $\begin{array}{l}\square \text { Fuel salt } \\
\square \text { Fuel processing } \\
\text { 囚 Off-gas }\end{array}$ \\
\hline $\begin{array}{l}\text { Cooling water system supplies water to space coolers for } \\
\text { the reactor, drain tank, coolant, and processing cells }\end{array}$ & Active & $\begin{array}{l}\text { 囚 Fuel salt } \\
\text { 囚 Fuel processing } \\
\text { 囚 Off-gas }\end{array}$ \\
\hline $\begin{array}{l}\text { Circulating gas system cools equipment in reactor and } \\
\text { drain tank cells }\end{array}$ & Active & $\begin{array}{l}\otimes \text { Fuel salt } \\
\square \text { Fuel processing } \\
\square \text { Off-gas }\end{array}$ \\
\hline $\begin{array}{l}\text { Cooling air supply cools FVs in coolant and fuel } \\
\text { processing cells }\end{array}$ & Active & $\begin{array}{l}\bigotimes \text { Fuel salt } \\
\text { Fuel processing } \\
\square \text { Off-gas }\end{array}$ \\
\hline $\begin{array}{l}\text { Doors around the radiator will shut automatically during } \\
\text { scram or loss of power }\end{array}$ & Active & $\begin{array}{l}\bigotimes \text { Fuel salt } \\
\square \text { Fuel processing } \\
\square \text { Off-gas }\end{array}$ \\
\hline $\begin{array}{l}\text { Electrical heaters surround most of the components } \\
\text { containing fuel salt }\end{array}$ & Active & $\begin{array}{l}\otimes \text { Fuel salt } \\
\square \text { Fuel processing } \\
\square \text { Off-gas }\end{array}$ \\
\hline
\end{tabular}


Table 5. SSCs and design features supporting the maintain control of radionuclides within the first barrier safety function

\begin{tabular}{|c|c|c|}
\hline SSC/design feature & $\begin{array}{c}\text { Active/passive/design } \\
\text { feature }\end{array}$ & $\begin{array}{c}\text { Applicable source } \\
\text { term(s) }\end{array}$ \\
\hline Low system operating pressure is maintained & Design feature & $\begin{array}{l}\bigotimes \text { Fuel salt } \\
\text { Fuel processing } \\
\text { 囚 Off-gas }\end{array}$ \\
\hline $\begin{array}{l}\text { Overflow volume of } 156 \mathrm{~L}\left(5.5 \mathrm{ft}^{3}\right) \text { is provided below the } \\
\text { fuel pump }\end{array}$ & Design feature & $\begin{array}{l}\otimes \text { Fuel salt } \\
\square \text { Fuel processing } \\
\square \text { Off-gas }\end{array}$ \\
\hline $\begin{array}{l}\text { Through a flexible piping arrangement, the pump and } \\
\text { heat exchanger are allowed to move to accommodate } \\
\text { thermal expansion of fuel salt }\end{array}$ & Design feature & $\begin{array}{l}\bigotimes \text { Fuel salt } \\
\square \text { Fuel processing } \\
\square \text { Off-gas }\end{array}$ \\
\hline $\begin{array}{l}\text { Lower seals of the fuel salt pump can accept pressure } \\
\text { transients as high as } 448 \mathrm{kPa}(65 \mathrm{psia}) \text { or as low as } \\
6.9 \mathrm{kPa}(1 \text { psia) without opening }\end{array}$ & Design feature & $\begin{array}{l}\bigotimes \text { Fuel salt } \\
\square \text { Fuel processing } \\
\square \text { Off-gas }\end{array}$ \\
\hline $\begin{array}{l}\text { Even though the sample enricher penetrates both the first } \\
\text { and second barriers, at least two barriers are provided at } \\
\text { all times to guard against the escape of radioactive gases } \\
\text { or particulates }\end{array}$ & Design feature & $\begin{array}{l}\bigotimes \text { Fuel salt } \\
\square \text { Fuel processing } \\
\square \text { Off-gas }\end{array}$ \\
\hline $\begin{array}{l}\text { Filters are in the lines between the fuel salt system and } \\
\text { the off-gas system }\end{array}$ & Design feature & $\begin{array}{l}\otimes \text { Fuel salt } \\
\square \text { Fuel processing } \\
\text { 囚 Off-gas } \\
\end{array}$ \\
\hline $\begin{array}{l}\text { The strength of the bolting and freeze flange compression } \\
\text { members are considerably greater than the strength } \\
\text { necessary to maintain a tight joint }\end{array}$ & Design feature & $\begin{array}{l}\otimes \text { Fuel salt } \\
\square \text { Fuel processing } \\
\square \text { Off-gas }\end{array}$ \\
\hline $\begin{array}{l}\text { High heat capacity of salt prevents melting of pipe wall } \\
\text { while salt is present }\end{array}$ & Passive (A) & $\begin{array}{l}\bigotimes \text { Fuel salt } \\
\text { 囚 Fuel processing } \\
\square \text { Off-gas }\end{array}$ \\
\hline $\begin{array}{l}\text { Valves are provided in the cooling inlet and outlet lines } \\
\text { of control rods to prevent fuel salt from being discharged } \\
\text { to the cell if a thimble develops a leak }\end{array}$ & Active & $\begin{array}{l}\bigotimes \text { Fuel salt } \\
\square \text { Fuel processing } \\
\square \text { Off-gas }\end{array}$ \\
\hline Coolant salt is operated at a higher pressure than fuel salt & Active & $\begin{array}{l}\bigotimes \text { Fuel salt } \\
\square \text { Fuel processing } \\
\square \text { Off-gas }\end{array}$ \\
\hline $\begin{array}{l}\text { The reactor is drained on high activity detected by } \\
\text { monitors in the off-gas system }\end{array}$ & Active & $\begin{array}{l}\otimes \text { Fuel salt } \\
\square \text { Fuel processing } \\
\square \text { Off-gas }\end{array}$ \\
\hline $\begin{array}{l}\text { The fuel salt pump bowl vents to auxiliary charcoal beds } \\
\text { if pressure exceeds } 173 \mathrm{kPag} \text { ( } 25 \mathrm{psig} \text { ) }\end{array}$ & Active & $\begin{array}{l}\square \text { Fuel salt } \\
\square \text { Fuel processing } \\
\bigotimes \text { Off-gas } \\
\end{array}$ \\
\hline $\begin{array}{l}\text { The inlet helium lines to the fuel drain tanks and the flush } \\
\text { tank automatically close on low header pressure }\end{array}$ & Active & $\begin{array}{l}\text { 囚 Fuel salt } \\
\square \text { Fuel processing } \\
\text { 囚 Off-gas } \\
\end{array}$ \\
\hline $\begin{array}{l}\text { Cooling gas to the rod drive units and thimbles } \\
\text { automatically cuts off in case of high radioactivity in the } \\
\text { fuel cell }\end{array}$ & Active & $\begin{array}{l}\otimes \text { Fuel salt } \\
\square \text { Fuel processing } \\
\square \text { Off-gas }\end{array}$ \\
\hline
\end{tabular}


Table 6. SSCs and design features supporting the maintain control of radionuclides within the second barrier safety function

\begin{tabular}{|c|c|c|}
\hline SSC/design feature & $\begin{array}{c}\text { Active/passive/design } \\
\text { feature } \\
\end{array}$ & $\begin{array}{c}\text { Applicable source } \\
\operatorname{term}(\mathrm{s})\end{array}$ \\
\hline $\begin{array}{l}\text { Vapor condensing system is provided to keep the } \\
\text { pressure below } 276 \mathrm{kPag} \text { ( } 40 \text { psig) during a maximum } \\
\text { credible accident }\end{array}$ & Passive (B) & $\begin{array}{l}\bigotimes \text { Fuel salt } \\
\square \text { Fuel processing } \\
\square \text { Off-gas }\end{array}$ \\
\hline $\begin{array}{l}\text { Seal-welded containment is provided around the reactor } \\
\text { and drain tank cells }\end{array}$ & Design feature & $\begin{array}{l}\otimes \text { Fuel salt } \\
\square \text { Fuel processing } \\
\square \text { Off-gas }\end{array}$ \\
\hline $\begin{array}{l}\text { Large heat capacity of containment minimizes pressure } \\
\text { excursions }\end{array}$ & Design feature & $\begin{array}{l}\bigotimes \text { Fuel salt } \\
\text { 囚 Fuel processing } \\
\square \text { Off-gas }\end{array}$ \\
\hline Fireproof structures minimize the consequences of fire & Design feature & $\begin{array}{l}\text { 囚 Fuel salt } \\
\text { 囚 Fuel processing } \\
\text { 囚 Off-gas } \\
\end{array}$ \\
\hline $\begin{array}{l}\text { A salt leak detection system is included; freeze flanges } \\
\text { are monitored for leakage }\end{array}$ & Active & $\begin{array}{l}\text { 囚 Fuel salt } \\
\text { 囚 Fuel processing } \\
\square \text { Off-gas }\end{array}$ \\
\hline $\begin{array}{l}\text { Reactor and drain tank cells are maintained at } 13.8 \mathrm{kPa} \\
\text { ( } 2 \text { psi) below atmospheric pressure by the ventilation } \\
\text { system }\end{array}$ & Active & $\begin{array}{l}\text { 区 Fuel salt } \\
\text { 囚 Fuel processing } \\
\square \text { Off-gas }\end{array}$ \\
\hline $\begin{array}{l}\text { A fire protection system is included, with supply from } \\
\text { ORNL, as well as on-site backup supply }\end{array}$ & Active & $\begin{array}{l}\text { 凶 Fuel salt } \\
\text { 囚 Fuel processing } \\
\text { 囚 Off-gas }\end{array}$ \\
\hline $\begin{array}{l}\text { A vent pipe allows any steam produced in the vessel skirt } \\
\text { (upon spilled salt) to escape at low pressure }\end{array}$ & Passive (B) & $\begin{array}{l}\otimes \text { Fuel salt } \\
\square \text { Fuel processing } \\
\square \text { Off-gas } \\
\end{array}$ \\
\hline $\begin{array}{l}\text { Automatic containment under pressure action shuts off } \\
\text { component-cooling blowers }\end{array}$ & Active & $\begin{array}{l}\bigotimes \text { Fuel salt } \\
\square \text { Fuel processing } \\
\square \text { Off-gas }\end{array}$ \\
\hline $\begin{array}{l}\text { Redundant radiation detectors on the cell evacuation line } \\
\text { include an automatic safety action to close the block } \\
\text { valve between the evacuation line and the stack }\end{array}$ & Active & $\begin{array}{l}\bigotimes \text { Fuel salt } \\
\bigotimes \text { Fuel processing } \\
\bigotimes \text { Off-gas }\end{array}$ \\
\hline $\begin{array}{l}\text { Redundant radiation detectors on the off-gas line include } \\
\text { an automatic safety action to close the block valve } \\
\text { between the off-gas line and the stack }\end{array}$ & Active & $\begin{array}{l}\square \text { Fuel salt } \\
\square \text { Fuel processing } \\
\bigotimes \text { Off-gas }\end{array}$ \\
\hline
\end{tabular}

\subsubsection{Summary of MSRE safety functions and supporting SSCs/design features}

The reactivity control function influences the amount of heat being generated within the fuel salt, and this heat generation rate dictates the rate at which energy must be removed from the fuel salt. The success criterion of the reactivity control function during accidents is to reduce the fission heat generation rate quickly enough to match any heat removal faults in the short term, which should prevent damage to the first barrier to release. MSRE SSCs and design features that satisfied this function, depending on the event sequence, included the control rod drive system, inherent reactivity feedbacks, and drain tank 
geometry. Another beneficial characteristic of the MSRE system design was the low amount of excess reactivity in the core at a given time, which restricted the maximum effects of reactivity-driven transients.

The chemical behavior control function ensures the structural integrity of the first barrier to release by preventing local high heat generation (e.g., fires or increased local fissile concentration), high radiation fields, or vulnerabilities to heat/stresses. The objective of this function is to reduce and maintain the rate of any undesired chemical reactions below an acceptable rate at all times. MSRE features that satisfied this function included the cover gas system, the chemical compatibility of the fuel and coolant salts, and materials selection.

The MSRE heat removal function would reject the heat produced within the first barrier, which would ultimately be transferred to the atmosphere. Paths to the atmosphere may have been directly from the within the first boundary to the atmosphere, or indirectly via the containment atmosphere. This MSRE heat removal function differs slightly when compared to a similar function in LWR designs: in some cases, the fuel salt must be actively heated to prevent it from freezing. Thus, the success criterion of this safety function is to provide enough cooling to prevent long-term damage to the physical boundaries of the first barrier without unintentionally overcooling the fuel salt. The shutdown heat can be removed from the fuel salt by two systems: (1) the main radiator and (2) the drain tank cooling system. Supporting systems/features would include the component cooling water system, the coolant salt loop, electric heaters, and natural circulation of the salts.

The function of controlling the radionuclides within the first barrier was performed by maintaining the structural integrity of the physical boundary of this barrier (which is defined for each major source term in Section 3.2). Similar to the characteristics of Sodium Fast Reactor (SFR) designs, the low system operating pressure of the fuel salt loop in MSRE provided an advantage in achieving this safety function over the higher design pressures of the primary systems in LWRs. This is because the pressure in the fuel salt loop was one or two orders of magnitude lower than in the pressure in LWR primary loops, even during transients. Furthermore, since MSRE did not generate electricity, there was no threat to the integrity of the first barrier due to a malfunction of balance of plant (BOP) equipment. ${ }^{18}$ Other features of the MSRE design that helped to control the radionuclides within the first barrier included (1) the construction of the fuel salt piping to allow for movement resulting from thermal expansion of fuel salt, and (2) the overflow volume provided below the fuel salt pump and the high thermal margins between operating temperature of the fuel salt and the loss of strength of the INOR-8 ${ }^{19}$ piping.

Similarly, control of the radionuclides within the second boundary was generally ensured by the integrity of the final radionuclide release barrier. Any failures of the first barrier that would have resulted in the release of radioactive material would be confined within this seal-welded containment. As previously mentioned, the success criterion of the confinement function within the second boundary preventing release is a release of no more than the design basis leakage rate of radionuclides from containment (1\% per day), even under internal pressures of $276 \mathrm{kPag}$ (40 psig). Salt leak detection, containment heating, ventilation, and air conditioning (HVAC), and the vapor-condensing system all work to fulfill this safety function.

\footnotetext{
18 The MSRE used air blowers to help reject the heat produced by fission, and a catastrophic hub and blade failure in one of these blowers physically damaged the coolant salt system [5]. Also, a loss of heat dump capability was experienced due to bearing failures in these blowers.

19 The MSRE literature refers to the fuel salt loop piping material as INOR-8; however, when the material was licensed to Haynes International the trade name for the material became Hastelloy $N{ }^{\circledR}$. This material is also frequently referred to as UNS 10003 or Alloy N.
} 


\subsection{ENUMERATION OF REACTOR SPECIFIC INITIATING EVENTS}

According to the LMP PRA development approach, the next tasks in the development of an exhaustive enumeration of reactor-specific IEs are (1) to identify the failure modes of each barrier and SSC providing a safety function and (2) to identify the challenges to prevent each of the failure modes for these barriers and SSCs. However, according to the American Society of Mechanical Engineers (ASME) / American Nuclear Society (ANS) advanced non-LWR PRA standard [16], these stages require the design to be subjected to "a number of systems analyses including Failure Modes and Effects Analysis (FMEA), Process Hazards Analysis (PHA), and other analyses specified in the selected design codes and standards.” Because the available references documenting the analyses performed on the MSRE design do not indicate that these types of systematic analyses were completed, future work must include the execution of a PHA (HAZOP; see Footnotes 16 and 17 above), as well as FMEA, to comprehensively investigate challenges to preventing SSC and barrier failures.

Before these industry-standard system analyses are completed, a preliminary set of MSRE operational modes and plant states can be postulated using MSRE design and operations reports [9] [12], as well as the list of safety functions derived in Section 3.3, to develop a preliminary list of MSRE IE categories based on the challenges presented to the safety functions of the system. Then, the preliminary hazards report [6] and the MSRE safety analysis documentation [7] [11] [24] can be used to populate each of these categories with IEs.

According to the MSRE Design and Operations Report on instrumentation [9], there are five operating modes defined for the MSRE control system:

1. Off - The reactor is shut down, with rod withdrawal prohibited, and a control rod is reverse active in case that power exceeds $1.5 \mathrm{MW}$ or in case the reactor period is less than 5 seconds. The fuel and coolant salt pump cannot be started but will continue to run if they are running and the system is switched to "Off," and the transfer, fill, and drain FVs are all under no-thaw conditions. Thus, the fuel salt is secured in the drain tanks.

2. Prefill - The primary requirement is that the reactor loop be maintained empty. Salt transfers among the drain tanks to the chemical processing plant or to/from the fuel storage tank are permitted during prefill, and no additional interlocked prohibitions are imposed other than restricting filling the reactor.

3. Operate - The transfer FVs between the fuel storage tank and the drain tanks must be frozen, and at least one FV between the reactor drain line and one of the fuel drain tanks must be open.

4. Operate-Start - Operate mode becomes Operate-Start when the reactor loop is filled to the correct level and the reactor drain valve is frozen. Reactor start with power generation not exceeding 1.5 MW is permitted.

5. Operate-Run - This mode is obtained by manual selection when conditions requisite to highpower operation have been met, and it is mutually exclusive from Operate-Start. The operator can choose whether to use the automatic rod controller or the programmed load control.

In addition to the operating modes listed above, information on the development of IEs for FHRs [26] analyzes several different operating modes and states that this information may be relevant to a more comprehensive analysis of the MSRE. The status of fuel processing equipment is not covered in the MSRE design and operations report on instrumentation, but it is discussed in the MSRE design and operations report on the fuel processing system [24]. These reactor modes and states are distinct from the other modes in how the systems are arranged and how they operate (control interlocks, valve positions, etc.). Accordingly, to account for the identified modes that were encountered during operation of the MSRE, the following additional operational modes and states are suggested: 
6. Maintenance

a. Purposeful disruption of second barrier integrity for maintenance procedures For remote handling equipment to reach some of the components in the reactor or drain tank cells, it may be necessary to remove the concrete roof shielding plugs. In this situation, the reactor is most likely in the Off state; however, the containment ventilation may be in an unusual arrangement during maintenance operations (e.g., air being exhausted from the reactor or drain tank cells to cause a down-flow of air through the openings in the cell roof).

7. Fuel processing

a. Removal of oxides

As mentioned previously, the fuel or flush salt in the fuel storage tank can be treated by $\mathrm{H}_{2}$ and $\mathrm{HF}$ to remove oxides in the fuel that result from contamination by moisture or oxygen. This operating state is distinct from the recovery of uranium because (1) different chemicals are used to treat the salt in the storage tank and (2) different chemical compounds are volatilized from the salt (and then enter the off-gas line).

b. Recovery of uranium

To volatilize and remove the uranium from the fuel/flush salt (in addition to other fission and activation products), the salt in the fuel salt storage tank can be fluorinated using equal volumes of helium and fluorine. The resulting $\mathrm{UF}_{6}$ is then captured on $\mathrm{NaF}$ absorbers outside of the fuel processing cell. Again, this operating state is a slightly different configuration of fuel processing equipment than the state in which oxides are removed from the salt.

8. Experimental

\section{a. Fuel salt sampling.}

Because MSRE was a test reactor, the system was intended to be operated (often temporarily) in operating states that may only adjust the configuration or control scheme slightly from the other operating states described above. One such operating state was the process of obtaining a fuel salt sample from the bowl of the fuel salt pump using the sampler-enricher. Because this sampler-enricher would penetrate both the first and second barriers to the release of fuel salt, the process of taking a sample would change which two barriers in the sampler-enricher component are actively performing as the first and second barriers. Additionally, the potentially radioactive off-gas from the sample collection process is vented to the auxiliary charcoal bed in the off-gas disposal system.

The preliminary MSRE PRA developed in this report primarily focuses on the IEs occurring during the more common operating states (i.e., Operate-Run or Off). However, a full analysis of the MSRE system would require consideration of IEs occurring during each operating state. Some interesting and relevant results can be generated from analyzing the less common operating states or procedures such as recovery of uranium, so a preliminary attempt was made during this effort to determine how event sequences starting in these operating states could be developed.

The final element needed before investigating the MSRE event sequences is a list of IEs that will be used when deciding which event sequence models should be developed. These IEs will serve as the starting point for event trees. Since some groups of IEs can involve event sequences with similar system responses to the required safety functions, a preliminary list of IE groups was developed. While some insight to the approach for generating a list of IE groups can be gained from the PRA examples for the Next Generation Nuclear Plant (NGNP) and PRISM, as shown in the LMP PRA white paper [15], the list of IEs below was developed in a more technology-neutral manner. This approach is similar to that practiced at the FHR LBE workshop [26]. The list also encapsulates the examples of some transients described in the IAEA Safety Guide for Level 1 Probabilistic Safety Assessment (PSA) [30], as well relevant examples within the 7 AOO groups used for Chapter 15 analyses for LWRs [31]. A preliminary 
list of IE groups for the MSRE, including at least one example of a specific IE in each group, is as follows:

1. Increase in heat removal by coolant system

a. Inadvertent raising of radiator door

b. Radiator blower overspeed

2. Decrease in heat removal from fuel salt (or increased electrical heat addition)

a. Coolant salt pump failure

b. Plugging in coolant salt loop

c. Plugged drain line

d. Failure of drain tank afterheat removal system

e. External heaters over-temperature

f. Inadvertent load scram

3. Decrease in fuel salt flow rate

a. Fuel pump failure

b. Plugging in fuel salt loop

4. Reactivity and power distribution anomalies

a. Unexpected criticality during startup

b. Fuel separation

c. Collection of separated fuel material in reactor core

d. Cold slug upon pump start

e. Uncontrolled rod withdrawal

5. Leakage of substance through the first barrier

a. Heat exchanger leak

b. Heat exchanger tube rupture

c. Leak of drain tank heat removal system

6. Decrease in fuel salt inventory for a given volume

a. Inadvertent melting of FV

7. Radioactive release from a subsystem or component

a. Leaking of FV

b. Leaking/failure of freeze flange

c. Ignition of charcoal beds in off-gas system

The example IEs in each group were derived largely from the discussion contained in the MSRE hazards and safety analyses [6] [7]. Although the above list is not intended to be comprehensive, most of the internal IEs in the MSRE that would require development of an event sequence model should fall within these general groups. For example, all of the 30 MSR-specific scenarios described in Dolan's Molten Salt Reactors and Thorium Energy [32] can be grouped under one of the IE groups identified.

The third step of the approach suggested by LMP to select LBEs for advanced reactors is to develop or update a PRA model for the design that can be used to provide estimates of the frequencies and consequences of each LBE. In the early design phases, the PRA may be of limited scope, have a coarse level of detail, and make use of engineering judgement more often than a completed PRA that would meet applicable PRA standards. The scope, level, and detail of the PRA are then enhanced as the design matures and more information becomes available. A simplified preliminary PRA with a relatively narrow scope was able to be developed for the MSRE using the PRA development process described by the LMP in conjunction with the previous steps of the LBE selection process. The structure and results of this model are discussed in greater detail in the next section of this report. 


\section{IDENTIFY LIST OF AOOS, DBES, AND BDBES}

To identify LBEs, three IEs were chosen from different subsystems of the MSRE. Using the MSRE literature, event trees were constructed, and individual event sequences (each with unique end-states) were developed based on the discussion of intended response by the MSRE safety system and operators. Fault tree analysis (FTA) was conducted using system diagrams and descriptions from the MSRE literature to estimate the failure rate of each of these systems or actions that would mitigate the severity of the event sequence. The probability of failure was then used in the event tree analysis (ETA) to calculate the estimated frequency (per reactor-year) of each event sequence. The ETA and FTA were conducted using commercially available software [33].

To develop the quantitative FTA results for the MSRE preliminary PRA, a database was created listing (1) the failure rate for each component, (2) the source of the information, and (3) the kind of component and type of failure associated with the failure rate in the reference. This information is provided in Appendix B. Some supply failure rates are not explicitly represented in the models (e.g., pump failure due to failure of electric supply is included under "all failure modes"). The following subsections describe the events models and provide the results of the ETA developed for this effort. The fault trees that determine the probability of failure for each gate in the event trees are contained in Appendix A of this report.

\subsection{DESCRIPTION OF MSRE EVENT SEQUENCES}

Each of the subsections below discuss the scenarios associated with each of the three IEs modeled for the MSRE.

\subsubsection{Inadvertent melting of FV-103 during full power operations: CCP failure}

The MSRE fuel salt circulating in the fuel salt loop was separated from the drain tank by a frozen salt plug in a FV (FV-103). This salt was maintained in a frozen state by cooling air that is blown across the FV via one of two air blowers. These blowers are known as component cooling pumps (CCPs) and are part of the component cooling system. The capacity of one of these pumps was sufficient to meet the system's cooling air needs, so the second CCP would remain in standby mode in case the first CCP failed [9]. If the cooling air ceased to blow across the FV, the system was designed so that the salt plug in the FV would melt in less than 15 minutes due to heating from the circulating fuel salt, and the fuel salt would then drain via gravity into the fuel salt drain tanks in the drain tank cell.

The hazard of concern in this scenario is the afterheat within the fuel salt resulting from the decay of fission products after sustained operation at full power. The limiting temperature of the drain tank structural material (INOR-8) — based on both the maximum allowable design stress [34] and the ultimate tensile strength [35] — can be extrapolated to occur between 900 and $1000^{\circ} \mathrm{C}$. Although these temperatures are applicable for long-term scenarios [32], $955^{\circ} \mathrm{C}\left(260^{\circ} \mathrm{C}\right.$ above the normal fuel salt hot leg temperature) is taken here to be a conservative estimate of the temperature that would produce a failure of the drain tank's structural integrity. According to MSRE safety analysis calculations [7], without heat removal from the drain tanks, the fuel salt would reach (and subsequently exceed) this limit within 8 hours of a drain from full power, as demonstrated by the plot in Figure 8.

The event tree modeled for this scenario is displayed in Figure 9. The IE for these sequences is a failure of CCP-1, the normally operating blower. This failure could be a mechanical failure within CCP-1 or a failure of the lube oil supply to CCP-1, since neither CCP can continue to operate without a supply of lube oil. The lube oil supply pumps for CCP-1 and CCP-2 were driven by the respective cooling pump 
motors. Upon failure of CCP-1, an operator in the control room ${ }^{20}$ would need to react to an alarm to initiate the operation of CCP-2. If the operator failed to start this backup blower, the pump would not be available to start, or if the pump failed to start, then the absence of cooling flow across FV-103 would allow the frozen salt plug to melt in less than 15 minutes. However, if CCP-2 started successfully, then the event sequence would not continue, and normal operation of the reactor system would be maintained without any release of radioactive material.

If the FV had melted, then the fuel salt from the fuel salt loop would have drained via gravity into the drain tank [7]. For the MSRE to operate at full nominal power, both FVs in the fuel salt lines between the fuel salt loop and the drain tanks (FV-105 and FV-106) would have been be thawed, providing an unobstructed flow path from the fuel salt loop to the drain tank [12]. In this analysis, it is assumed that the hot salt contains enough thermal energy to prevent it from freezing during the draining of the fuel salt loop, so once FV-103 melted, the entire inventory of fuel salt would have drained into a drain tank. It was also assumed that the entire inventory of fuel salt drained into a single drain tank, Drain Tank No. 1, although both drain tanks and heat removal systems were identical. Therefore, the entire afterheat removal load was the responsibility of a single drain tank afterheat removal system at once.

Another consequence of this assumption was that the entire fuel salt inventory could be released into containment by the failure of the drain tank. Reliable operation of the drain tank afterheat removal system required the following [9]:

1. That the feedwater tanks contain a supply of cooling water,

2. That an ample supply of cooling water was available to the condensers,

3. That the system included reliable valves to admit water to the steam drums, and

4. That reliable block valves were provided in the drain lines from the steam drums.

A daily checklist was relied upon to ensure that the feedwater tanks contained water. A solenoid valve opened to admit water automatically to the steam drum when the fuel salt temperature in the drain tank exceeded $704^{\circ} \mathrm{C}\left(1300^{\circ} \mathrm{F}\right)$ and it reclosed at approximately $649^{\circ} \mathrm{C}\left(1200^{\circ} \mathrm{F}\right)$. This valve was in parallel with a manual valve, which could be controlled by the level indication if placed in automatic mode by the operator, and two valves served as a redundant means of admitting water to the steam drum. The condensers would typically be cooled by tower cooling water, but a diversion valve could provide an alternate supply of water instead. Loss of tower water pressure caused by a loss of water or pump shutdown was detected by a pressure switch, which operated the diversion valve. The diversion valve could also be controlled by a manual switch located in the water room on the water panel. When the diversion valve operated, the cooling water supply was shifted from the tower to the process water main. Since the heating of the drain tank to dangerous temperatures would occur gradually, over the course of 8 hours, it was also possible to make connections from the cooling water system to a tank truck in the event that the normal process water supply had become inoperative.

There were 10 thermocouples in the drain tank that read out on a thermocouple scanner. The scanner generated an alarm in the control room to notify the MSRE operators of high temperature [9]. If the afterheat removal system in the drain tank operated successfully, then the drain tank integrity was retained and the fuel salt remained in the drain tank with no release of radioactive material. The drain lines of the steam drums were used to keep the tanks dry during normal operation. Control instrumentation closed a pair of redundant valves in the drain lines when the reactor cell pressure exceeded $+13.8 \mathrm{kPag}(+2.0 \mathrm{psig})$ or when the radiation monitors in the cell evacuation line indicated excessive radioactivity in the cell atmosphere. Manual switches were provided on a junction box in the north electric service area, which

\footnotetext{
${ }^{20}$ At any time during reactor operations, there were at least one supervisor or chief operator and two technicians in the control room [12].
} 
was a relatively remote area, but the operator would have ample time to reach these switches. Additionally, there were load cells on the drain tanks that indicated the inventory of these tanks to the operators.

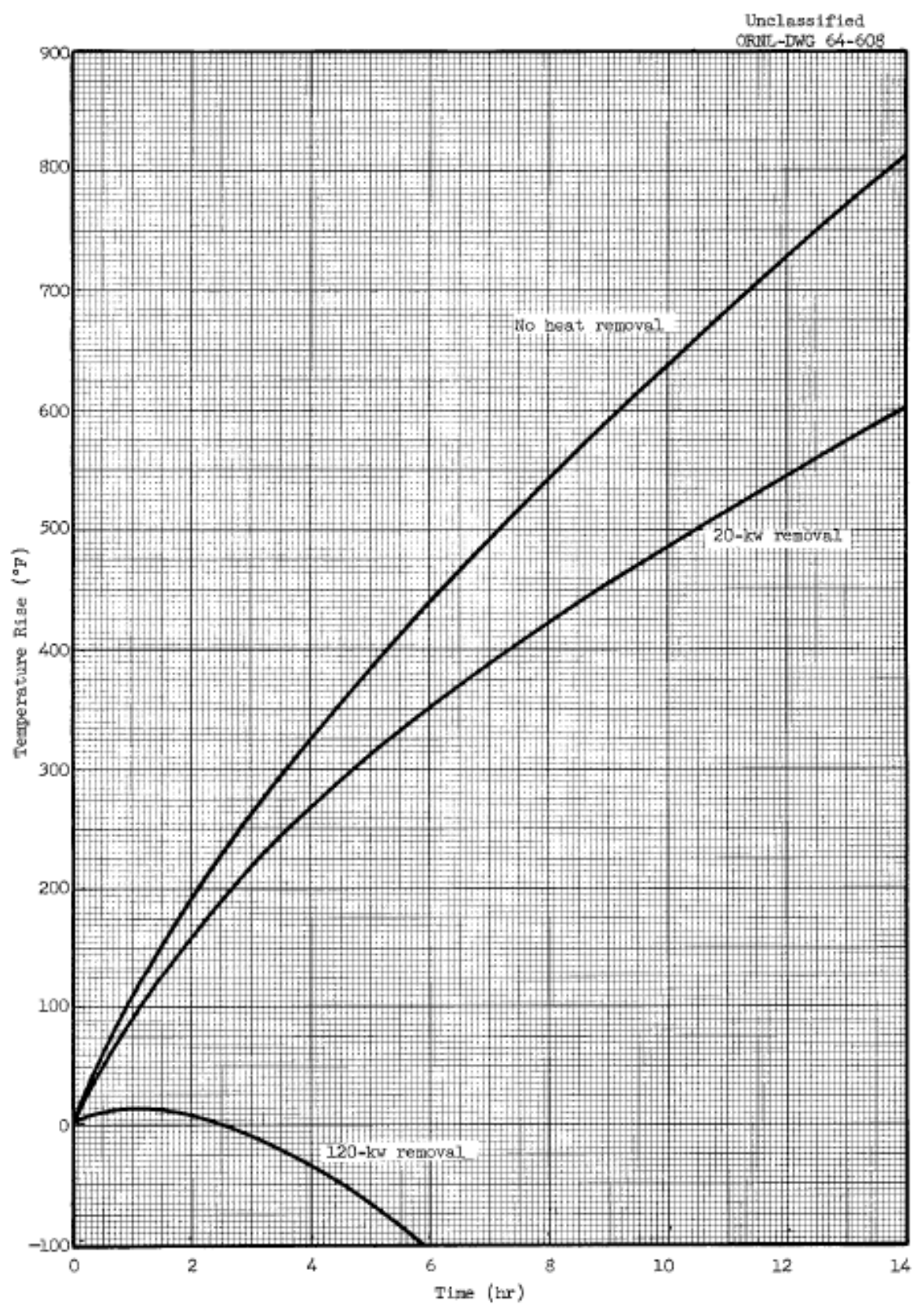

Figure 8. Temperature rise of fuel in drain tank beginning $15 \mathrm{~min}$ after reactor operation for $1,000 \mathrm{hr}$ at 10 MW [7].

Upon failure of the drain tank, it was assumed that the entire inventory of fuel salt was released into the drain tank cell. During normal MSRE operation, pressure in the reactor cell was maintained at -13.8 kPag (-2 psig) by evacuating a small flow of reactor cell atmosphere through a small $1 / 4$-inch bypass line (not shown in Figure 13) before being discharged to the MSRE stack [12]. This line bypassed the normally closed block valve (shown in Figure 13) and contained a ceramic filter. However, upon the detection of high radioactivity in this exhaust (as would be the case if fission products were released into the drain tank or the reactor cell), a pneumatic valve in the reactor cell evacuation line upstream of this bypass line 
was automatically closed by the MSRE safety system. Shutting this valve could be triggered by either of two independent radiation switches or by a manual switch in the control room. A high level of radiation could be indicated from control room annunciators, which were associated with the level indicated by the radiation monitors in the reactor cell evacuation line or by a high alarm originating from any of the three radiation monitors in the stack. If the reactor cell evacuation line were not successfully isolated, then the radioactive gases released into the cell could be exhausted to the atmosphere though this bypass line. The driving pressure for this release would be greater if one of the two stack fans were running.

The final aspect that would affect the end-state of this event was operation of the building's ventilation system when the pneumatic valve in the reactor cell evacuation line was closed. According to calculations in the MSRE safety analysis report, equilibration of $453 \mathrm{~kg}(1000 \mathrm{lb})$ or more of spilled fuel salt with the reactor cell's atmosphere alone would result in a rise in cell pressure to about 18 psig [7]. In addition, the final gas and salt temperature would be around $649^{\circ} \mathrm{C}\left(1200^{\circ} \mathrm{F}\right)$. If the evacuation line were closed off, then the ability to maintain the reactor and drain tank cells at a negative differential pressure through the bypass line would be lost. Thus, diffusion of radioactive gases and particles outside of the cell to high-bay and other areas of the MSRE building would be possible. If one of the two stack fans were operating, then the diffused radioactivity would be drawn through filters before being exhausted to the stack. These filters would likely reduce the total amount of radioactive particles exhausted to the atmosphere (by about 99.9\%). However, if the ventilation system were not operating, then these radioactive particles would be able to diffuse outside of the MSRE building and could result in a larger total release from this event [7].

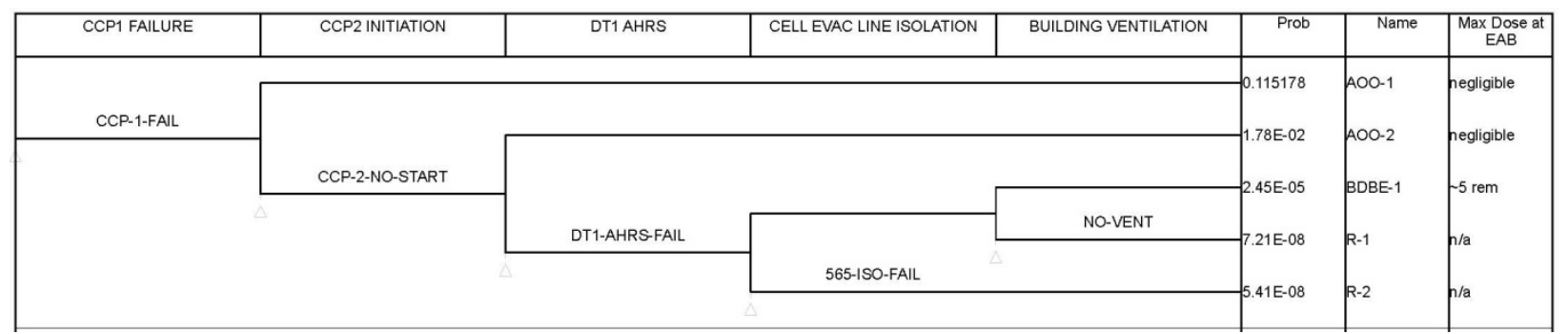

Figure 9. Event tree for failure of component cooling blower (CCP-1).

\subsubsection{Uncontrolled withdrawal of control rods}

Another scenario of concern that was analyzed in the MSRE safety analysis report [7] is the uncontrolled withdrawal of the control rods from the core. Figure 10 shows that potentially dangerous temperatures could be reached within the fuel salt in just 15 seconds $^{21}$ if all three of the MSRE control rods were withdrawn simultaneously. This occurs when starting with the reactor at just critical, at a power level of 0.002 watt. For this event sequence, it was assumed that the IE (spurious withdrawal of all 3 control rods) occurred with the reactor in normal operation mode. The event tree developed for this scenario is shown in Figure 11.

\footnotetext{
${ }^{21}$ The change in fuel density with temperature is not included in the calculation displayed in Figure 10 due to the limitations on the computational resources available at the time of the calculation. This phenomenon would likely be a significant negative feedback mechanism on the timescale considered and would be included in modern simulations for a more realistic representation of the scenario.
} 

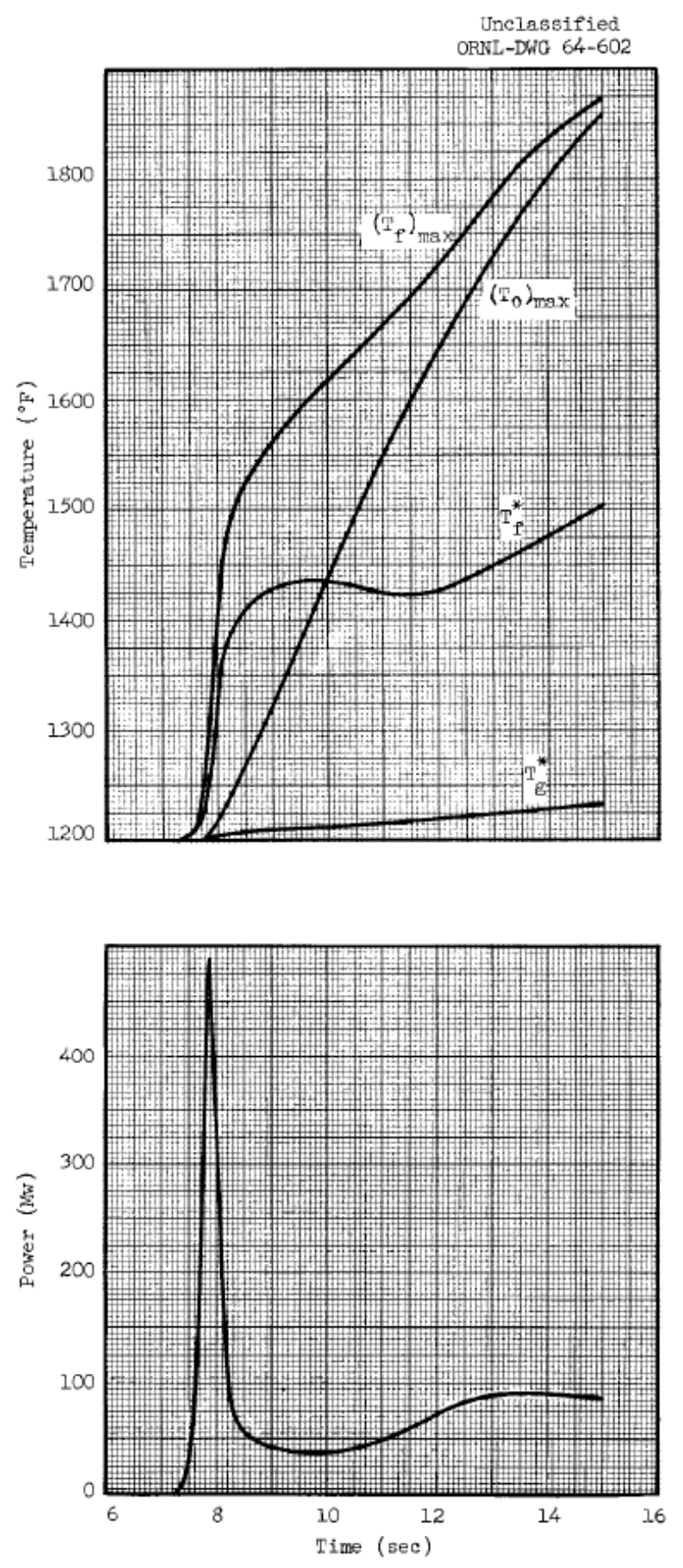

Figure 10. Power and temperature transients produced in the MSRE core by uncontrolled rod withdrawal without a reactor scram [7]. 
To prevent increases to temperatures that may threaten the integrity of the fuel salt piping, the MSRE had three different trips that would automatically break the circuit supplying power to the electromagnetic clutches in the control rods. This in turn was intended to drop the rods into the core and scram the reactor. The reactor trips for high flux ( $>15 \mathrm{MW}$ ) and low reactor period $(<1 \mathrm{sec})$ originated from the same flux channels in the core, and the temperature measurements used to initiate a scram due to high fuel salt temperature come from three independent temperature channels at the outlet of the core $\left(>704^{\circ} \mathrm{C}\right.$ or $1300^{\circ}$ $\mathrm{F})^{22}$. The MSRE operators could also initiate a scram using the manual scram switch in the control room. If the supercriticality of the core were caused by the withdrawal of all three control rods, then only two of the three rods would need to be reinserted into the core to prevent the maximum fuel temperature from exceeding $716^{\circ} \mathrm{C}\left(1320^{\circ} \mathrm{F}\right)$, even with the third rod still being withdrawn [7].

After a reactor scram, the automatic response by the MSRE safety system was to [9]:

1. Initiate the draining of the fuel salt loop to the drain tanks by closing the valves supplying cooling air to the FV between the fuel salt loop and the drain tanks (FV-103),

2. Open vent valves to the drain tanks, and

3. Close valves to equalize the pressure between the gas space in the drain tank and the gas space in the fuel salt pumps.

According to calculations in the MSRE safety analysis [7], if the draining of the fuel salt loop were not successful, then the maximum temperature of the fuel salt remaining in the fuel salt loop could have exceeded $940^{\circ} \mathrm{C}\left(1,725^{\circ} \mathrm{F}\right)$ within 48 hours.

However, if the fuel salt were drained to the drain tank, then the remainder of the event sequence would be similar to the event sequence for the failure of CCP-1 discussed in Section 4.1.1. Assuming that the fuel salt had been operating in the fuel salt loop at power, the decay heat in the fuel salt would need to be removed to prevent a threat to the physical integrity of the drain tank. One difference between this scenario and the situation in which both CCPs have failed would be that with an operating CCP, the FVs in the draining system could be frozen by opening valves and introducing cooling air to the FVs in the fuel salt lines. Thus, it would be possible to transfer the hot fuel salt from one drain tank to the other in the case of a failure of the drain tank afterheat removal system for one of the drain tanks.

To transfer the fuel salt from drain tank (DT)-1 to DT-2, FV-105 and FV-106 would need to be frozen and freeze valves FV-108 and FV-109 would need to be thawed [12]. In addition to these actions, the valve to allow venting from DT-2 to the auxiliary charcoal bed should be opened, and the valves that allow venting from the drain tanks to the normal charcoal bed need to be closed. Drain Tank No. 1 can then be pressurized to force the fuel salt into DT-2. If the afterheat removal system in DT- 1 operates successfully or the salt were successfully transferred to DT-2 and the afterheat removal system in DT-2 operated successfully, then this accident could be mitigated without any release of radioactive material. However, if both afterheat removal systems failed or if the afterheat removal system in DT-1 failed and the fuel salt could not be moved to DT-2, then temperatures of the fuel salt in the drain tank could reach values high enough to threaten the structural integrity of the tank containing the salt.

\footnotetext{
${ }^{22}$ For a scram to be initiated, any 2 of the 3 channels must be beyond the scram setpoint [9].
} 


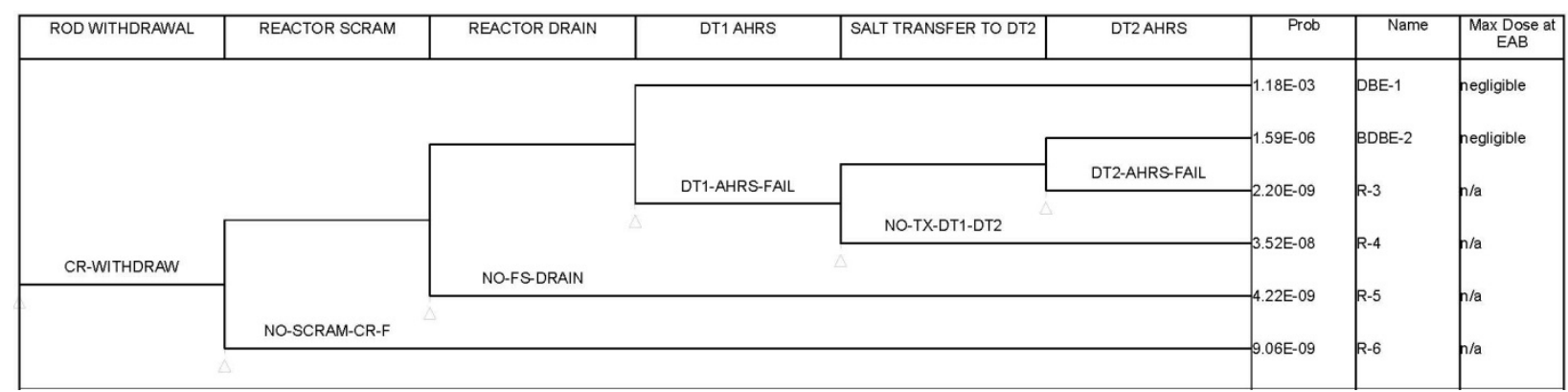

Figure 11. Event tree for uncontrolled withdrawal of control rods.

\subsubsection{Leak from off-gas holdup}

One pathway for radioactivity to get to the MSRE's reactor cell atmosphere (and to possibly be released further) would be via a rupture or a leak in the off-gas disposal system's piping. As discussed in Section 3.1, the helium cover gas flow leaving the pump bowl in the off-gas line contained a non-negligible amount of volatile radioactive fission products (e.g., Kr, Xe, and some I). This stainless-steel pipe was $1 / 2$ inch in diameter, widening to 4 inches in diameter via a disconnect flange. This section of 4 -inch pipe was $~ 21$ meters (68 feet) long and included a serpentine section to provide a holdup volume allowing for a delay of about one hour for the decay of short half-life radioactive fission products [4]. The off-gas line then continued through the reactor cell wall into the coolant cell as $1 / 2$-inch pipe after the holdup section, and the gas was then routed through carbon beds for further decay before being routed to the stack to be diluted and exhausted. The event tree model of a leak from the off-gas piping within the reactor cell is provided in Figure 12.

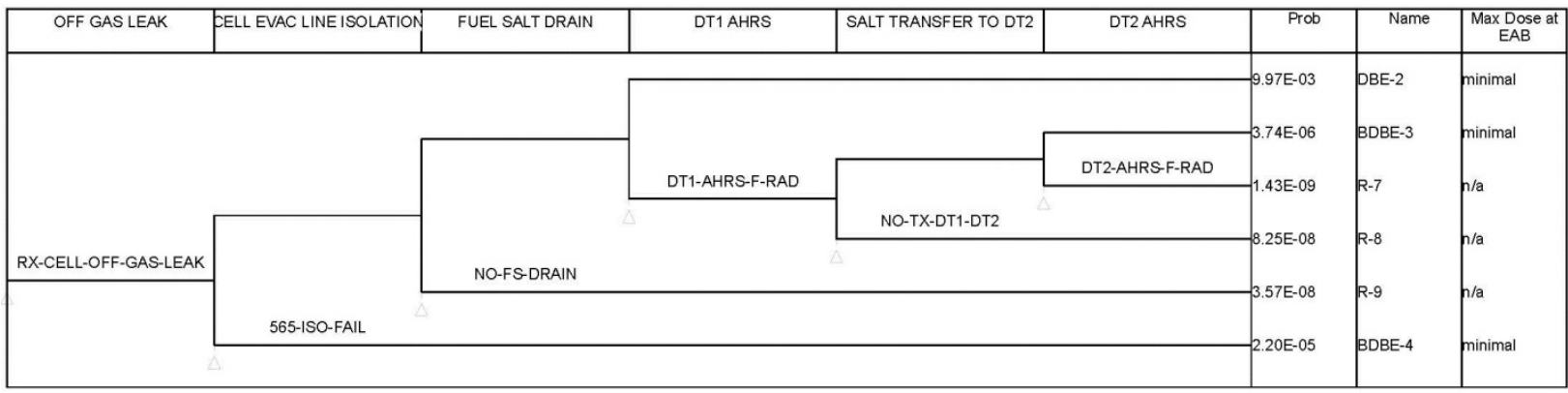

Figure 12. Event tree for leak in off-gas holdup piping.

A leak or rupture in the off-gas piping contained within the reactor cell or a failure of a disconnect flange would release radioactive gases to the reactor cell's atmosphere. Figure 13 presents the cell evacuation line, the off-gas system, the MSRE stack, and the important instrumentation in these subsystems. The two radiation monitors in the cell evacuation line ${ }^{23}$ were intended to detect the high radiation levels in the cell atmosphere and automatically initiate the closing of a pneumatic valve in this line to prevent contaminated cell atmosphere from being exhausted out of the off-gas stack. Even if the MSRE safety system failed to automatically initiate the closing of this pneumatic valve based on the monitors in the cell evacuation line, high radiation levels ${ }^{24}$ measured by the detectors on the evacuation line or by any of the

\footnotetext{
${ }^{23}$ As mentioned in Section 3.2.1, this cell evacuation line is used to exhaust reactor cell atmosphere to the stack in order to maintain a negative pressure in this cell relative to the MSRE building.

${ }^{24}$ Although the setpoint for safety system action or excessive radioactivity alarms is not specified in the MSRE Instrumentation and Controls Reports [9] [10], the Operating Safety Limits report states that the release of radioactive materials from the ventilation stack shall not exceed 0.62 microcuries/sec of I, 79 millicuries/sec of noble gases, and 36 microcuries/sec of other mixed fission products [48].
} 
three stack gas monitors would trigger audible and visible alarms in the control room and in the ORNL central monitoring facility to notify operators of this occurrence [9]. The pneumatic valve in the cell evacuation line could then be closed via operator actuation of a manual switch in the control room, and the closing of this valve would isolate the bypass line used to maintain a negative differential pressure in the reactor cell. If this bypass line were successfully isolated from the stack, then the amount of radioactivity released via the stack would be limited to the amount of radioactive gas capable of diffusing out of the reactor cell once the negative pressure between the cell and the remainder of the building is lost due to the termination of the reactor cell evacuation flow.

The MSRE safety system would automatically trigger the fuel salt loop to drain if a high radiation alarm occurred from either of the radiation detectors in the reactor cell evacuation line. However, even if the fuel salt were not drained, then the fuel salt system would be capable of avoiding dangerously high temperatures due to the $30 \mathrm{~kW}$ radiative heat losses from the reactor vessel at $649^{\circ} \mathrm{C}\left(1,200^{\circ} \mathrm{F}\right)$ [7]. If the fuel were successfully drained from the reactor after operating at power for a significant length of time, then the afterheat would need to be removed by successful operation of the drain tank afterheat removal system. In contrast to the two previously discussed event sequences, the high radiation alarm in the reactor cell evacuation line would automatically trigger the valves in the drain lines of the drain tank steam domes to close and would allow operation of the afterheat removal system in either drain tank; thus, these valves would not necessarily need to be closed by operator action. Furthermore, if the afterheat removal system in one drain tank were not capable of removing the decay heat from the fuel salt, then the fuel salt inventory could be transferred to the other drain tank.

To end the flow of radioactive gas into the reactor cell from a failed off-gas line and to minimize the total radioactivity released to the reactor cell, it would be imperative that the fuel salt be drained from the fuel salt loop and the reactor drain tank off-gas flow be directed through the auxiliary off-gas charcoal beds. The bypass valve from the drain tank into the main off-gas line would automatically open during an emergency drain; thus, the valve must be closed once the fuel salt is secured in one of the two drain tanks. By using this alternative flow path instead of the flow path through the normal off-gas charcoal beds, the radioactive gases evolving from the fuel salt in the drain tank would not have to travel past the failure in the off-gas line and would be given a long enough residence time in the auxiliary charcoal bed to decrease the levels of radioactivity before release to the environment via the MSRE stack. 


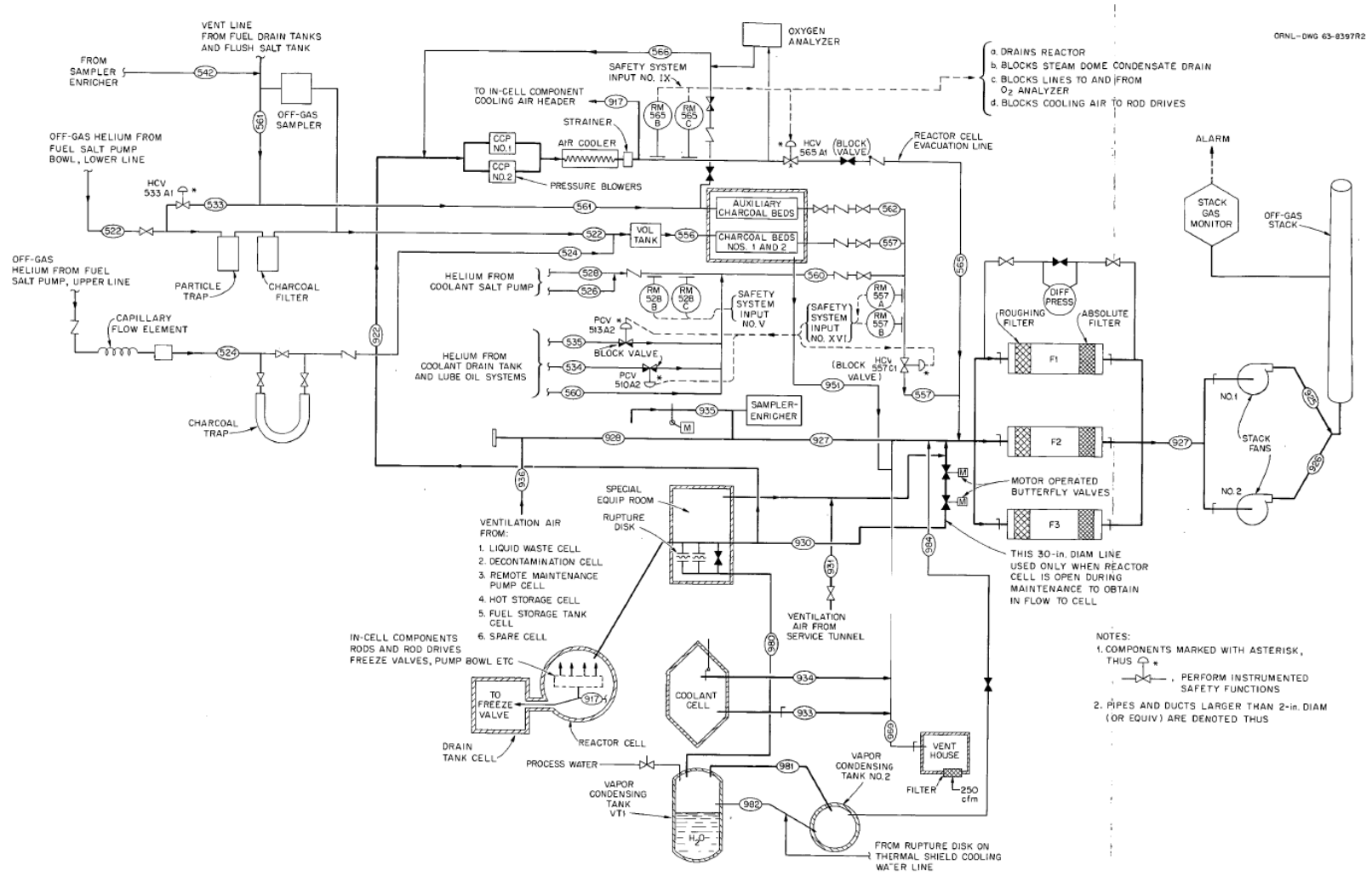

Figure 13. Gas systems exhausting via the MSRE stack [9]

\subsection{IDENTIFYING MSRE LBEs}

Once the fault trees and event trees have been used to calculate probability for each MSRE event sequence, the next step is to identify the licensing basis events (LBEs). These LBEs are classified based on the following definitions proposed by the LMP [2]:

Anticipated operational occurrences (AOOs) encompass planned and anticipated events, the frequencies of which exceed $10^{-2}$ /plant-year. ${ }^{25}$ Radiological doses from AOOs are required to meet normal operation public dose requirements. AOOs are used to establish operating limits for normal operation modes and states.

Design basis events (DBEs) ${ }^{26}$ encompass unplanned off-normal events with frequencies in the range of $10^{-4}$ to $10^{-2} /$ plant-year. These events are not expected in the plant's lifetime but may occur in the lifetimes of a fleet of plants. DBEs are the basis for the design, construction, and operation of the SSCs during accidents and are proposed to be used to provide input to the definition of DBAs.

Beyond Design Basis Events (BDBEs) are rare off-normal events with frequencies ranging from $5 \times 10^{-7} /$ plant-year to $10^{-4}$ /plant-year. BDBEs are evaluated to ensure that they do not pose an unacceptable risk to the public.

In this report, event sequences with probabilities less frequent than the $5 \times 10^{7} /$ plant-year threshold were considered to be residual risk. These event sequences are numbered R-1 through R-9 in the ETA, and the consequences for these highly unlikely events were not estimated.

\footnotetext{
${ }^{25} \mathrm{~A}$ plant may be comprised of one or more reactor modules. In this analysis, since the MSRE is the only plant considered, 1 plant-year $=1$ reactor-year.

${ }^{26}$ Note: this terminology is different than current NRC Part 50 definition for design basis events.
} 
A summary of the frequency and consequence for each of the MSRE LBEs identified by the ETA is presented in Table 7. This section of the report discusses how the consequences were estimated for each of the LBEs, as grouped by IE. In the simplified treatment of the event sequences in this work, the only consequences considered are doses to off-site personnel. Off-site is defined as beyond 3,000 $\mathrm{m}$ from the MSRE building [7]. Rather than using the mean dose at the EAB as recommended by the LMP approach, the doses reported in this work are based on the maximum off-site dose due to the availability of quantified estimates and the incorporation of conservatism.

Table 7. Summary of frequency and consequence of analyzed MSRE LBEs

\begin{tabular}{|c|c|c|}
\hline Sequence & Frequency (year-1) & Consequence \\
\hline AOO-1 & 0.115 & Negligible - no release \\
\hline AOO-2 & $1.78 \mathrm{E}-02$ & Negligible - no release \\
\hline DBE-1 & $1.18 \mathrm{E}-03$ & Negligible - no release \\
\hline DBE-2 & $9.97 \mathrm{E}-03$ & Minimal \\
\hline BDBE-1 & 2.45E-05 & $\sim 5$ rem max dose at $\mathrm{EAB}$ \\
\hline BDBE-2 & $1.59 \mathrm{E}-06$ & Negligible - no release \\
\hline BDBE-3 & $3.47 \mathrm{E}-06$ & Minimal \\
\hline BDBE-4 & $2.20 \mathrm{E}-05$ & Minimal \\
\hline
\end{tabular}

\subsubsection{CCP failure LBEs and consequences}

In the case of an unanticipated melting of a FV leading to a drain of the fuel salt loop due to failures in the component cooling system, two AOOs and one BDBE were identified. AOO-1 is the event sequence in which the operating component cooling pump (CCP-1) fails, but the standby blower (CCP-2) is successfully initiated by operator action. Because only one of these blowers is needed to supply the cooling gas flow needed to operate the reactor system, normal operation of the reactor can be maintained, and there is no release of radioactive material; thus, there is no dose at the EAB as a result of AOO-1.

AOO-2 is the event sequence resulting from a failure of both component cooling pumps, but a successful initiation of the afterheat removal system in the drain tank once the inventory of the fuel salt loop has drained to DT-1. The operation of this afterheat removal system is sufficient to prevent dangerous temperatures from being reached in the drain tank, so the fuel salt is secured in the drain tank without any release of radioactive material from the system, and there is no dose at the EAB as a result of AOO-2.

BDBE-1 represents the scenario in which both CCPs fail, the fuel salt is drained to the drain tank, and the afterheat removal system fails to successfully operate and remove the decay heat from the fuel salt in the tank. There would be no cooling water available in the drain tank bayonets to remove heat from the salt if both steam drum drain line block valves failed or if both valves that could supply cooling water to the steam drum were not able to be opened. As illustrated in Figure 8, without heat removal, the fuel salt in the drain tank will reach temperatures that may threaten the structural integrity of the drain tank within 8 hours. Because the component cooling system is not able to be used to "close" the FVs in the fuel salt transfer lines (by using freezing air to freeze the salt plugs in the valves), the operators would not able to transfer the fuel salt from DT-1 to DT-2. In this analysis, it was assumed that the entire fuel salt inventory was released to the drain tank cell upon the failure of the drain tank afterheat removal system in a scenario similar to the maximum credible accident analyzed in the MSRE safety analysis [7].

The maximum credible accident (MCA) analyzed in "MSRE Design and Operations Report Part V: Reactor Safety Analysis Report" [7] is the release of the entire inventory of fuel salt to the reactor cell, accompanied by the inleakage of the correct amount of water to allow the generation of steam without subsequent cooling from additional inleakage of water. After the pressure in the cell rises to about 276 $\mathrm{kPag}$ (40 psig), the reactor cell's return to atmospheric pressure is aided by the actuation of the MSRE's 
vapor condensing system. In BDBE-1, the driving force for the release of radioactivity would be lower than that seen in the MCA, because an absence of steam results in a cell pressure increase to only about $124 \mathrm{kPag}$ (18 psig), according to MSRE calculations [7]. ${ }^{27}$ However, in BDBE-1, this pressure transient would not burst the rupture disk to engage the vapor condensing system [4]. In this work, it was assumed that the duration of radionuclide leakage out of the cell in BDBE-1 would be long enough to produce the same dose at the EAB as that calculated for the MCA. According to the MSRE calculations [7, Appendix $\mathrm{A}]$, the maximum dose at the $\mathrm{EAB}$ (under inversion conditions) after releasing the entire fuel salt inventory to the reactor cell with the building ventilation operating is 4.6 rem from exposure to iodine, with an additional 2 mrem from exposure to solid fission products. ${ }^{28}$

\subsubsection{Uncontrolled control rod withdrawal LBEs and consequences}

After the IE of the uncontrolled withdrawal of all three MSRE control rods, the ETA identified one DBE and one BDBE. DBE-1 is the event sequence in which the MSRE safety system successfully scrams the reactor (either on high flux, low reactor period, or high fuel salt outlet temperature), and then the fuel salt is successfully drained from the fuel salt loop and can be secured in the drain tank by successful operation of the afterheat removal system.

BDBE-2 is the situation in which the reactor scrams and the fuel salt is drained, but the afterheat removal system in DT-1 fails. However, unlike the event sequences that result from the failure of the component cooling pumps, the fuel salt can be transferred successfully to DT-2, where the decay heat can be removed by successful operation of the afterheat removal system for this drain tank. Neither of these event sequences results in the release of any radioactive material, so the consequence for both of these LBEs is a negligible dose at the EAB.

\subsubsection{Off-gas leak LBEs and consequences}

Analysis of the event sequences occurring after the IE of a leak in the portion of the off-gas components in the reactor cell identified one DBE and two BDBEs. DBE-2 is the scenario in which the cell evacuation line is able to be isolated from the stack flow, the fuel salt is successfully drained to the drain tank, and the successful initiation of the afterheat removal system in the drain tank is able to secure the fuel salt in the drain tank. Similarly, BDBE-3 is the scenario in which the cell evacuation line is isolated, the fuel salt is drained, and then it is transferred and secured in DT-2 (after failure of the afterheat removal system in DT-1). The consequences associated with these LBEs are described as minimal rather than negligible because some gaseous fission products (e.g., Kr, Xe, I) would be released from the leak in the off-gas line during the period of time between the initiation of the leak and the securing of the fuel salt in the drain tank (likely between 30 minutes and 1 hour [5]). This radioactive gas in the reactor cell would have the opportunity to diffuse to the MSRE building once the cell evacuation line is secured and the negative pressure differential is lost between cell and the building. However, due to the lack of a strong driving force behind this diffusion, the relatively short period of time for this gas to build up in the cell, and the

\footnotetext{
${ }^{27}$ It is assumed that the consequences of a release of fuel salt to the drain tank cell would be similar to those of the MCA because, as mentioned in Section 3.2.1, the reactor cell and drain tank cell were interconnected via a duct (36-inch ID), and a gas flow of $\sim 340 \mathrm{~m}^{3} / \mathrm{hr}$ from the component cooling system circulated air from the drain tank cell into the reactor cell.

${ }^{28}$ The MSRE calculation that predicted the $124 \mathrm{kPag}$ (18 psig) final cell pressure due to a release of the entire inventory of fuel salt to the reactor cell does not take into account the cooling capability of the water filled annulus around the reactor cell, nor does it reflect the tortuous path that the radionuclides would have to travel to leak to the high bay area after being released to the bottom of the drain tank cell. Thus, the calculated pressure transient is conservative in nature. It is likely that a more realistic simulation of this scenario would indicate a smaller challenge to the reactor cell and thus a lower dose consequence at the EAB.
} 
availability of surfaces onto which iodine could plate out, ${ }^{29}$ it is assumed that the dose at the EAB resulting from DBE-2 or BDBE-3 would not be significant. Further calculations considering the leak rate, the duration of the leak, the constituents of the gas released to the reactor cell, and the diffusion of the cell atmosphere to the MSRE building, are needed to accurately quantify the radioactivity released during these event sequences. Overall, the dose consequences associated with both of these event sequences are minimized because the fuel salt is drained to the drain tank and the off-gas is then routed through the auxiliary charcoal bed.

By contrast, in BDBE-4, the off-gas leak into the reactor cell would not be isolated from the stack by the valve in the reactor cell evacuation line. ${ }^{30}$ Although the radioactive isotopes in the off-gas flow from the pump bowl were mainly $\mathrm{Kr}$ and $\mathrm{Xe}$ [21], some of the iodine from the fuel salt could have been volatilized and carried into this line. However, as mentioned before, during normal operations the evacuated reactor cell atmosphere would need to flow through a small 1/4-inch line (not shown in Figure 13) before being discharged to the MSRE stack [4]. This line bypassed the normally closed block valve (shown in Figure 13) and contained a ceramic filter. Additionally, once the reactor cell atmosphere was cooled at the outlet of the CCP, it would be likely that the iodine would plate out onto the roughing and/or stack filters in between the bypass line and the stack or adhere to particles that would be retained by these filters. The combination of the reduced line size and the performance of the ceramic, roughing, and stack filters would drastically reduce the amount of iodine released and minimize the dose consequences associated with this event sequence. As a result of these design features, the radioactive material released to the environment would essentially be composed only of $\mathrm{Kr}$ and $\mathrm{Xe}$. These isotopes were determined not to be capable of producing any significant dose at the MSRE EAB [7], but further analysis regarding the exact radioisotopic composition of the off-gas flow is needed to more precisely quantify the dose at the EAB resulting from this event sequence.

\subsection{EVALUATING MSRE LBEs AGAINST LMP SUGGESTED FREQUENCY VS DOSE CURVE}

To visually represent the risk of individual LBEs, the LMP has suggested the use of a frequencyconsequence curve (sometimes referred to as a Farmer curve). The frequencies and maximum doses at the EAB associated with the LBEs identified for the MSRE are shown on the LMP curve in Figure 14.

\footnotetext{
${ }^{29}$ Because the EAB is so far from the MSRE building, iodine is the only isotope that significantly affects dose at the EAB [7]. Furthermore, the MSRE safety analysis estimated that at least $50 \%$ of iodine released to the reactor cell would plate out on surfaces [7].

${ }^{30}$ In the case that neither CCP is running, the release of radioactive material to the environment in this scenario would occur only via slow diffusion.
} 


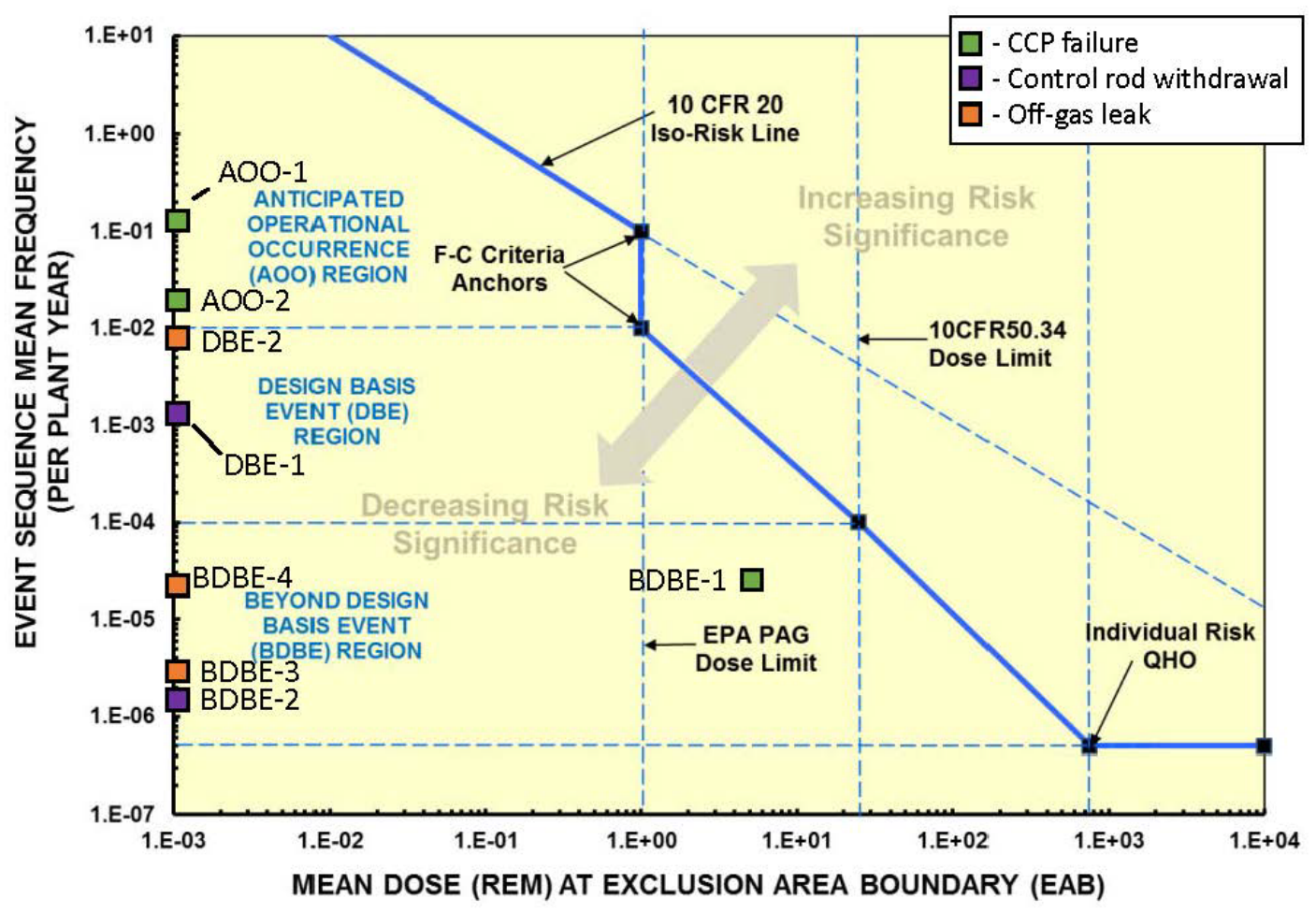

Figure 14. Calculated frequency and consequences ${ }^{31}$ for MSRE LBEs compared to the frequency vs. dose curve suggested by the LMP [5].

The rationale behind the curve and the interpretation of the specific dose limits that give the curve its shape have been analyzed in detail [2] [36]. However, rather than using this curve as risk acceptance criteria, the LMP suggests that the primary purpose of this frequency-consequence is to evaluate the risk significance of individual LBEs and use it as a tool in the selection and evaluation of LBEs [36]. The results displayed in Figure 14 suggest that BDBE-1 is the most risk-significant LBE identified in this analysis. ${ }^{32}$ Additionally, if this safety assessment were being performed on a reactor design that was not yet finalized, then more attention to the safety systems that would mitigate this accident (thus reducing the frequency or the consequence of the event sequence) would be in the best interest of the designers to allow for a more robust safety case.

The final step of the LBE selection process applied in this work was to group the event sequences modeled and evaluated in the preliminary PRA based on event sequence frequency. The risk insights produced by the analysis of the reactor design allow for the initial set of deterministically selected LBEs to be revised and further emphasis placed on the more risk significant event sequences. For the MSRE, many simplifying assumptions were made, including point estimates of component failure rate and conservative estimates of dose consequences; however, risk-significant IEs and design decisions could still be derived by comparing the relative risk of each IE and event sequence analyzed. Additionally, the LBEs with no release are still important to identify challenges to SSCs that are responsible for preventing or mitigating a release of radioactive material.

\footnotetext{
${ }^{31}$ Note: The doses calculated for the MSRE LBEs are maximum doses at the EAB rather than the mean dose criteria suggested by the LMP since these dose estimates were readily available in the existing MSRE safety analysis

${ }^{32}$ As discussed in Section 4.2.1, above, it is possible that more accurate calculations could demonstrate that the consequences associated with BDBE-1 are significantly lower than those assumed in this work
} 


\section{CONCLUSIONS}

Using the LBE selection and PRA development approaches for advanced Non-LWRs suggested by the LMP provided risk insight specific to the design and safety of the MSRE. This process also helped highlight important concepts relevant to modern MSR design and safety assessment. One specific observation that can be seen from the quantitative FTA results is that the installation of the drain lines in the steam drums of the drain tank afterheat removal systems increased the risk in scenarios when draining the fuel salt is needed, but the valves would not be triggered to close by the MSRE safety system. When these valves required closing by operator action, the frequency of the afterheat removal system failing to adequately remove decay heat from the fuel salt was notably increased.

Additionally, viewing the risk significance of the LBEs on the frequency-consequence plot can draw attention to event sequences that may have benefitted from further attention by MSRE systems designers. However, the highly conservative nature of the dose estimates that are available for those event sequences that do result in a release of radioactive material highlights a potential challenge when estimating dose consequences at the EAB for releases from advanced reactors. Especially in the case of MSRs, radionuclides can be in unfamiliar physical states and/or chemical compounds, complicating the analyses necessary to estimate the dose consequence associated with such a release. The simplistic nature of the calculations for the consequences of BDBE-1 highlights this difficulty. It is likely that more realistic simulations of a salt spill would demonstrate that the sequence does not result in dose consequences at the $\mathrm{EAB}$; however, it was necessary to make conservative simplifying assumptions in order to place the results on the frequency-consequence plot suggested by the LMP. To compare the risk significance of event sequences and design decisions in an advanced reactor at an early stage of design, when the exact fuel composition may be unknown, it could be beneficial to use a simpler consequence measure that parallels the core damage frequency used in LWR Level 1 PRAs or the large early release frequency used in LWR Level 2 PRAs. These types of risk surrogates could reduce the complexity of the deterministic calculations needed to quantitatively estimate risk.

Another observation evident in comparing the quantitative frequency and consequence results to the LMP criteria is that, out of the IEs identified, not many of the sequences falling into the LBE range of frequencies have any dose consequences. Thus, retrospectively, the benefit from PRA analysis of the MSRE is largely limited to evidence that supports the safety of the MSRE design. However, if the development of this preliminary PRA had been conducted during the design stage of the MSRE, then these zero-consequence sequences could have been used to shape the functional requirements of the barriers that prevent the release of radioactive material to the environment.

Regarding the use of hazard assessment in the development of the preliminary PRA, the MSRE Preliminary Hazards Report was helpful in developing accident sequences since the document discusses intended system responses that mitigate the scenario. However, contributions from a more comprehensive hazards assessment approach would have been useful in other steps of the preliminary PRA development. For example, it is evident from Tables 2-6 that the ORNL safety analysis prior to operation of the MSRE was much more thorough in identifying hazards and mitigating SSCs and design features for the fuel salt system than for the other two major source terms (i.e., the off-gas and fuel processing systems). Analysis of the off-gas system and the barriers preventing the release from this source were particularly sparse. A HAZOP study could have been used to further identify additional IEs and associated event sequences, and FMEA would be necessary to ensure complete identification of all IEs. Using these modern PHA methodologies to identify IEs would also allow for the grouping of these IEs in a more technology-neutral manner, as these studies tend to focus on all possible deviations from nominal operating conditions rather than limiting the safety analysis to those scenarios that are typically considered for more traditional reactor designs. 
A challenge experienced when reviewing the existing MSRE literature to develop an accurate understanding of system design and operations was tracking the evolution of this historical information over the course of the MSRP at ORNL. In some cases, changes were made to the configuration of certain systems in the time between the publication of MSRE reports that affected the development of the FTA and/or ETA. One example of such a change is the installation of the steam dome condensate drain lines in the drain tank afterheat removal systems. These drain lines are not pictured in the drain tank flowsheets in the MSRE design and operations report describing system design [4] or in the same flowsheets replicated in the appendix of the safety analysis [7]. However, these lines and their operation are discussed in the later reports on instrumentation and controls [9] [10]. Similarly, conflicts between descriptions of the exact arrangement of the fuel handling and processing equipment are present in the MSRE design and operations report on fuel handling and processing [24, Figure 2.2] and the ORNL report documenting the performance of the fuel processing equipment [37, Figure 1]. In analyses of historical reactor designs, it will be important to evaluate and document the quality and applicability of the existing literature, perhaps in an approach similar to that described for evaluating historic technology information for use in advanced reactor licensing [38].

Finally, the results of this work identify a concept that is relevant to the safety assessment of liquid-fueled MSRs. In contrast to the IEs considered for safety assessment of LWRs, IEs in auxiliary systems such as component cooling systems and off-gas handling systems can directly lead to the release of radioactive materials in the case of liquid-fueled MSRs. Many accidents that are considered in the safety assessment of current reactor designs (e.g., step reactivity insertion) are analyzed in the MSRE safety analysis [6] and are determined to be effectively mitigated by design features of the system (e.g., reactivity feedbacks and thermal margin). Furthermore, the auxiliary systems in MSRs will likely involve the use of components with relatively less commercial nuclear experience (e.g., charcoal beds for the decay of a significant amount of gaseous fission products). These facts, supported by the results of this work, emphasize the importance of (1) accurately characterizing the size and composition of the different source terms in an MSR, and (2) analyzing the behavior of the system after failures that occur outside the fuel salt loop. 


\section{REFERENCES}

1. Nuclear Energy Institute (NEI), "Licensing Technical Requirement Modernization Project," ML17013A140, Washington, DC, January 2017.

2. Southern Company, "Modernization of Technical Requirements for Licensing of Advanced NonLight Water Reactors,” Draft report Revision 0, ML17104a254, April 2017.

3. C. Gabbard, "Reactor Power Measurement and Heat Transfer Performance in the Molten Salt Reactor Experiment,” ORNL-TM-3002, May 1970.

4 R. Robertson, “MSRE Design and Operation Report Part I: Description of Reactor Design,” ORNLTM-728, January 1965.

5. R. Guymon, "MSRE Systems and Components Performance,” ORNL-TM-3039, June 1973.

6. S. Beall, W. Breazeale, and B. Kinyon, "Molten-Salt Reactor Experiment Preliminary Hazards Report,” ORNL-CF-61-2-46, February1961.

7. S. Beall, P. Haubenreich, R. Lindauer, and J. Tallackson, "MSRE Design and Operations Report Part V: Reactor Safety Analysis Report,” ORNL-TM-732, August 1964.

8. W. Cottrell, W. Ergen, A. Fraas, F. McQuilkin, and J. Meem, “Aircraft Reactor Test Hazards Summary Report,” ORNL 1935, January 1955.

9. J. Tallackson, "MSRE Design and Operations Report Part IIA: Nuclear and Process Instrumentation,” ORNL-TM-729, February 1968.

10. R. Moore, "MSRE Design and Operations Report Part IIB: Nuclear and Process Instrumentation,” ORNL-TM-729, September 1972.

11. P. Haubenreich, J. Engel, C. Gabbard, R. Guymon, and B. Prince, "MSRE Design and Operation Report Part V-A: Safety Analysis of Operations with U-233,” ORNL-TM-2111, February 1968.

12. R. Guymon, “MSRE Design and Operations Report Part VIII: Operating Procedures,” ORNL-TM908, Volume I, December 1965.

13. R. Guymon, "MSRE Design and Operations Report Part VIII: Operating Procedures,” ORNL-TM908, Volume II, January 1966.

14. M. Langston, "Continuing Evolution of US Nuclear Quality Assurance Principles, Practices, and Requirements-Part I,” ASME Standards Committee on Nuclear Quality Assurance, August 2005.

15. Southern Company, "Modernization of Technical Requirements for Licensing of Advanced NonLight Water Reactors Probabilistic Risk Assessment Approach,” Draft Report for Collaborative Review ML17158B543, June 2017.

16. ASME/ANS, "Probabilistic Risk Assessment Standard for Advanced Non-LWR Nuclear Power Plants,” ASME/ANS RA-S-1.4-2013, December 2013.

17. US Department of Energy, "Development of Probabilistic Risk Assessments for Nuclear Safety Applications,” DOE-STD-1628-2013, November 2013.

18. International Atomic Energy Agency (IAEA), "Component Reliability Data for Use in Probabilistic Safety Assessment,” IAEA, Vienna, Austria, 1988.

19. Center for Chemical Process Safety (CCS), "Guidelines for Process Equipment Reliability Data with Data Tables,” CCPS, New York, NY, 1989.

20. R. Kedl, "The Migration of a Class of Fission Products (Noble Metals) in the Molten-Salt Reactor Experiments,” ORNL-TM-3884, December 1972.

21. E. Compere, E. Bohlmann, S. Kirslis, F. Blankenship, and W. Grimes, "Fission Product Behavior in the Molten Salt Reactor Experiment,” ORNL-4865, October 1975.

22. D. Williams, "MSR Chemistry, Materials Compatibility, and Separations," Reactor Nuclear Systems Division Seminar, Oak Ridge National Laboratory, June 26, 2017. 
23. M. Bell, “Calculated Radioactivity of MSRE Fuel Salt,” ORNL-TM-2979, May 1970.

24. R. Lindauer "MSRE Design and Operations Report Part VII: Fuel Handling and Processing Plant," ORNL-TM-907 (revised), December 1967.

25. R. Briggs, “Additional Calculations of the Distribution of Tritium in the MSRE,” ORNL-CF-71-7-8, July 1971.

26. University of California, Berkeley, "Fluoride-Salt-Cooled, High-Temperature Reactor (FHR) Subsystems Definition, Functional Requirement Definition, and Licensing Basis Event (LBE) Identification White Paper,” UCBTH-12-001, August 2013.

27. International Atomic Energy Agency, "Safety of Nuclear Power Plants: Design,” IAEA Safety Standards Series No. SSR-2/1, 2012.

28. US Department of Energy (DOE), "Probabilistic Risk Assessment for the Standard Modular High Temperature Gas-cooled Reactor,” DOE-HTGR-86-011, Revision 3, Volume 1, January 1987.

29. International Atomic Energy Agency (IAEA), "Safety related terms for advanced nuclear plants," IAEA, Vienna, Austria, IAEA-TECDOC-626, September 1991.

30. International Atomic Energy Agency, "Development and Application of Level 1 Probabilistic Safety Assessment for Nuclear Power Plants,” IAEA Safety Standards Series No. SSG-3, Vienna, Austria 2010.

31 US Nuclear Regulatory Commission. "Standard review plan for the review of safety analysis reports for nuclear power plants (NUREG-0800)." March 2007.

32. T. Dolan, Molten Salt Reactors and Thorium Energy, Woodhead Publishing, 2017.

33. Electric Power Research Institute (EPRI), "CAFTA-Fault Tree Analysis System, Version 6.0b," 2014 Program 41.07.01.

34. R. Robertson, “Conceptual design study of a single-fluid molten salt breeder reactor,” ORNL-4541, 1971.

35. Haynes International, Inc., HASTELLOY N alloy, https://www.haynesintl.com/pdf/h2052.pdf, 2002.

36. US Nuclear Regulatory Commission (NRC), "Public meeting on possible regulatory process improvements for advanced reactor designs," slide presentations, ML17177A244, June 22, 2017.

37. R. Lindauer, "Processing of the MSRE Flush and Fuel Salts,” ORNL-TM-2578, August 1969.

38. G. Honma, "Guidance on Evaluating Historic Technology Information for use in Advanced Reactor Licensing,” Idaho National Laboratory (INL), INL/EXT-15-35805, October 2015.

39. E. Blandford, "Risk-informed Design Guidance for Advanced Reactor Concepts: A Case Study of the Pebble Bed Advanced High Temperature Reactor,” University of California, Berkeley. 2008.

40. F. Silady, "Safety Classification of Structures, Systems, and Components for the Pebble Bed Modular Reactor,” IAEA Safety Standards, No. SSG-30, 2014.

41. International Nuclear Safety Advisory Group, "Defense in Depth in Nuclear Safety, INSAG-10," IAEA, Vienna, Austria, 1996.

42. J. Krepel, B. Hombourger, C. Fiorina, K. Mikityuk, U. Rohde, S. Kliem, and A. Pautz, "Fuel cycle advantages and dynamics features of liquid fueled MSR,” Annals of Nuclear Engineering, Http://dx.doe.org/10.1016/j.anucene.2013.08.007, 2013.

43. D. Williams and F. Peretz, "Characterization of the Molten Salt Reactor Experiment Fuel and Flush Salts,” ANS Conference Summary, Reno, Nevada, 1996.

44. A. Icenhour, D. Williams, L. Trowbridge, L. Toth, and G. Del Cul.” An Overview of Radiolysis Studies for the Molten Salt Reactor Experiment Remediation Project,” ORNL Presentation at the Global 2001 Conference, Paris, France, 2001.

45. M. Haghighi, M. Ford, R. Szozda, and M. Jugan, "Waste Stream Generated and Waste Disposal Plans for Molten Salt Reactor Experiment at Oak Ridge National Laboratory,” WM’02 Conference Paper, Tuscon, AZ, 2001.

46. C. Forsberg, J. Stempien, M. Minck, and R. Ballinger, "Understanding and pathways to Avoid Major Fuel Failures and Radionuclide Releases in Fluoride Salt-Cooled High-Temperature Reactor 
Severe Accidents,” Nuclear Technolgy, Volume 1994, http://dx.doi.org/10.13182/NT15-87, June 2016.

47. Center for Chemical Process Safety (CCPS), “Guidelines for Hazard Evaluation Procedures, $3^{\text {rd }}$ Ed.” John Wiley \& Sons, April 2008.

48. R. Guymon and P. Haubenreich, "MSRE Design and Operations Report Part VI: Operating Safety Limits for the MSRE,” ORNL-TM-733 (Rev3), July 1969. 

APPENDIX A. MSRE Fault Tree Diagrams 



\section{APPENDIX A. MSRE FAULT TREE DIAGRAMS}

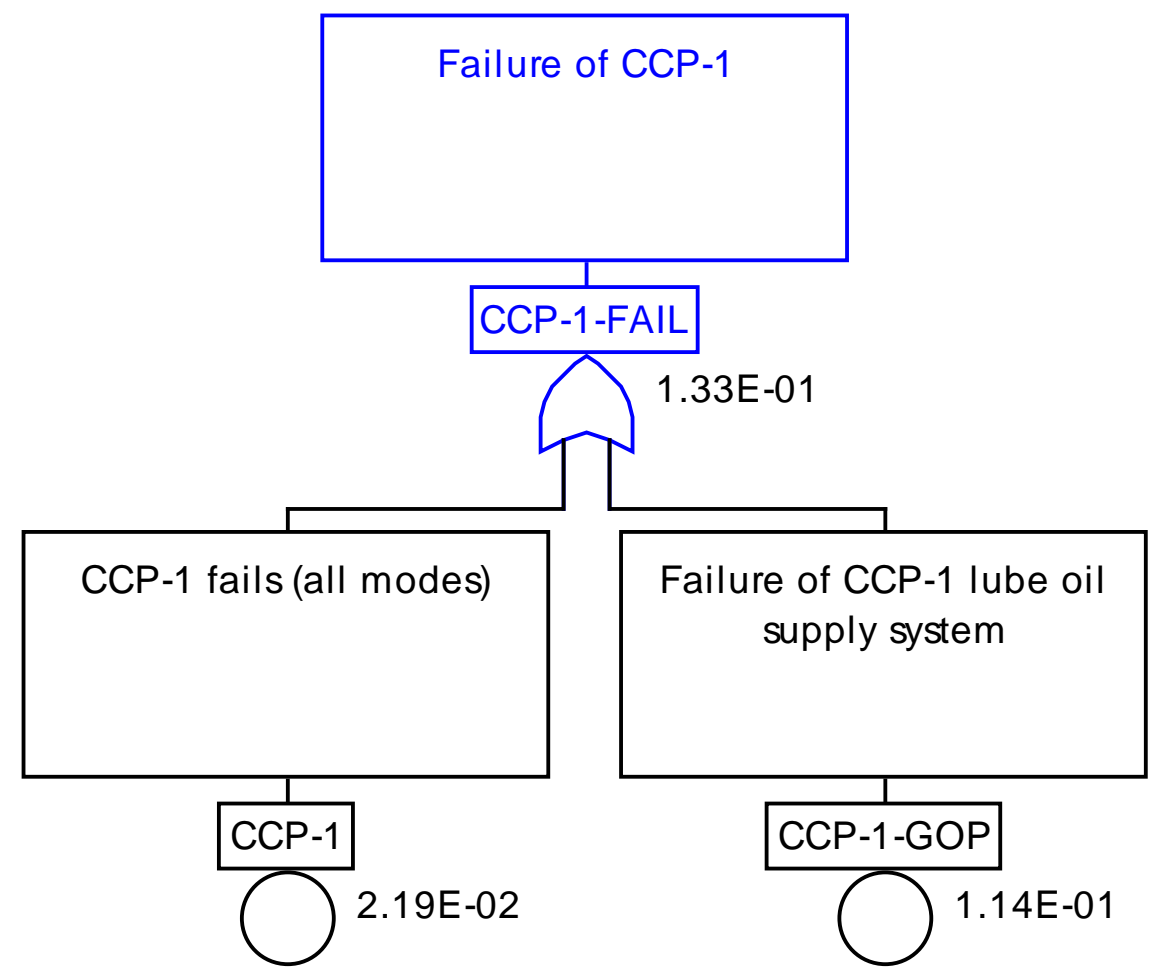

Figure A-1. Fault tree for failure of operating component cooling blower (CCP-1). 


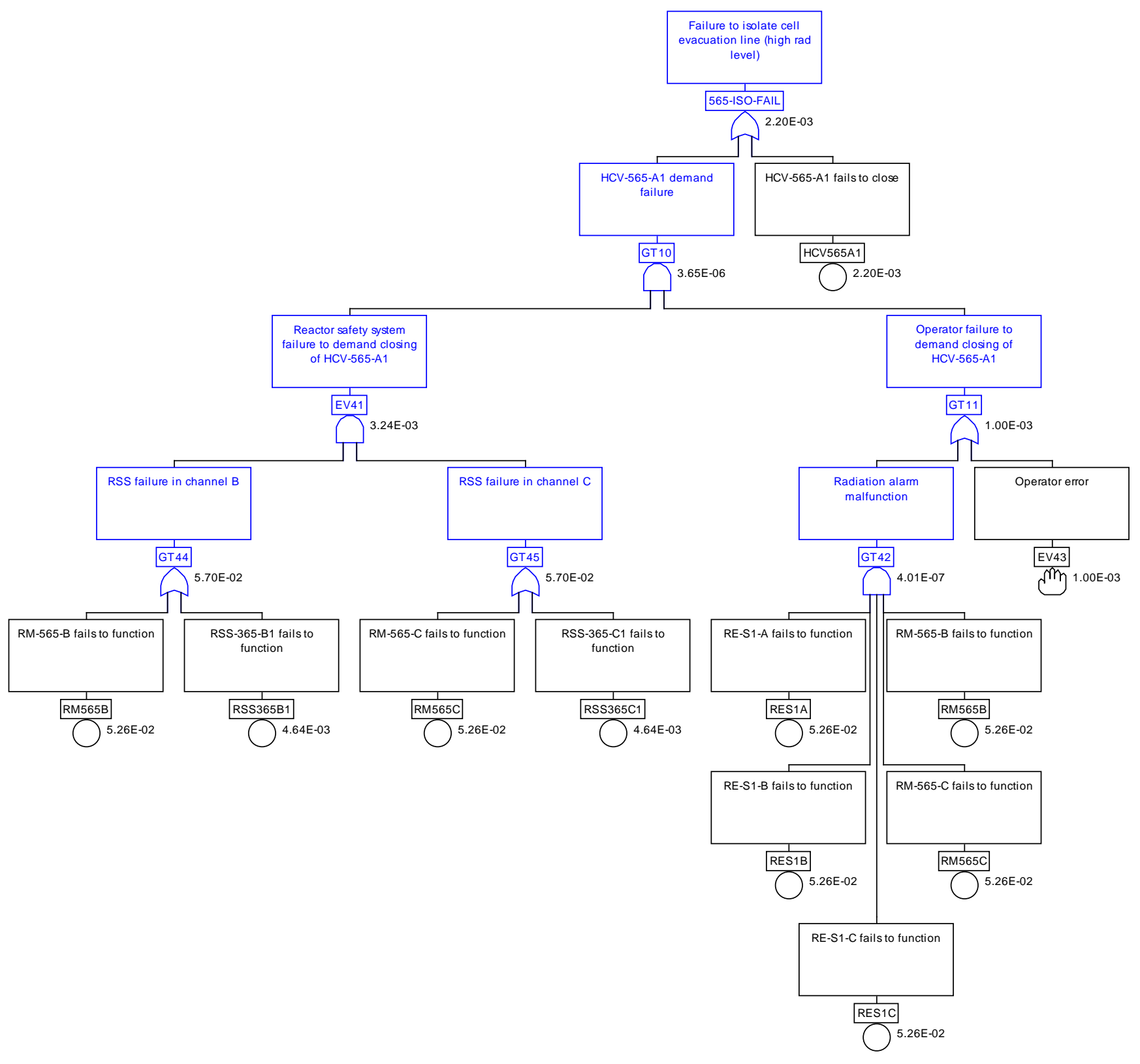

Figure A-2. Fault tree for failure to isolate reactor cell evacuation line. 


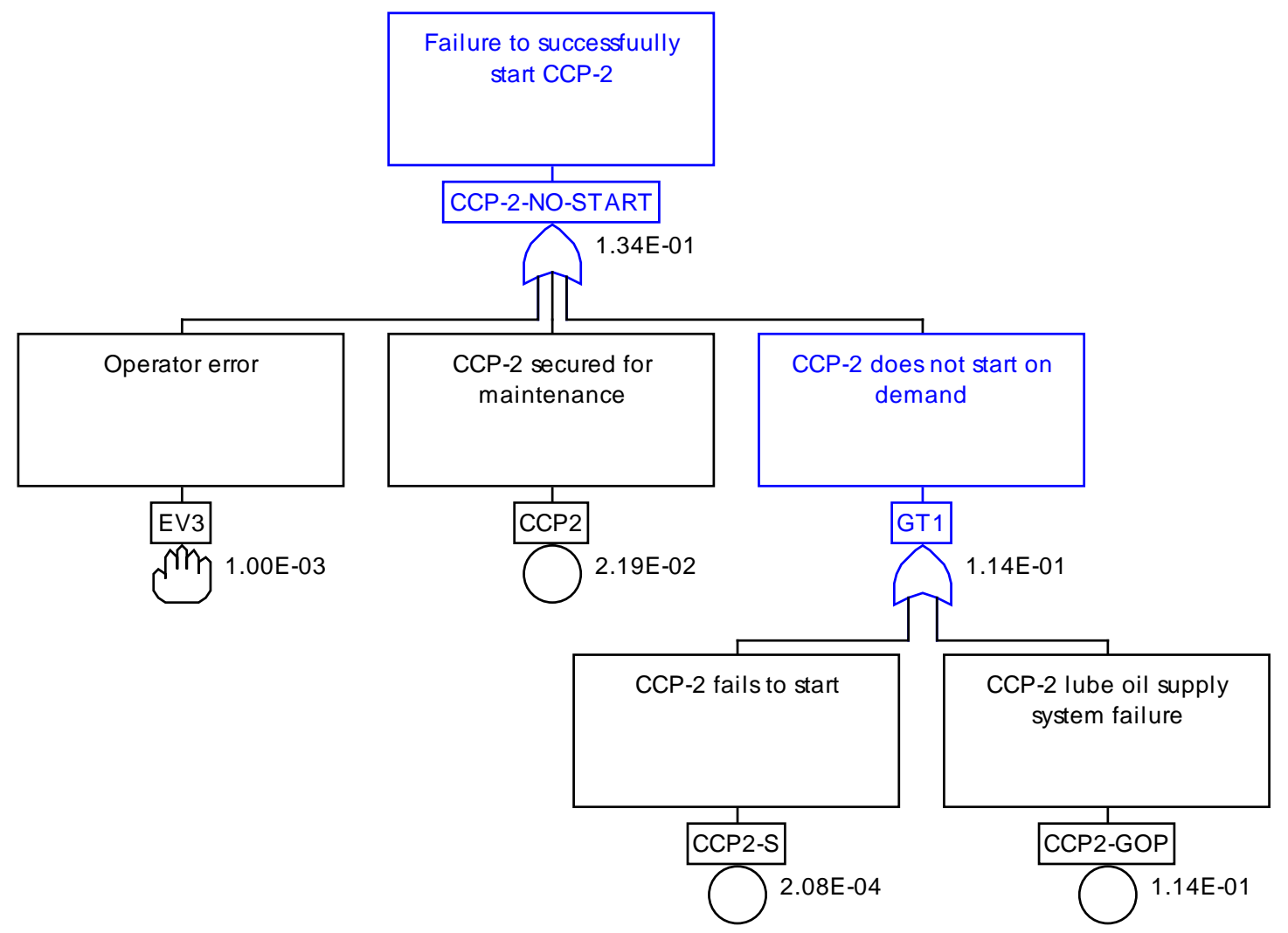

Figure A-3. Fault tree for failure to start standby component cooling blower (CCP-2). 


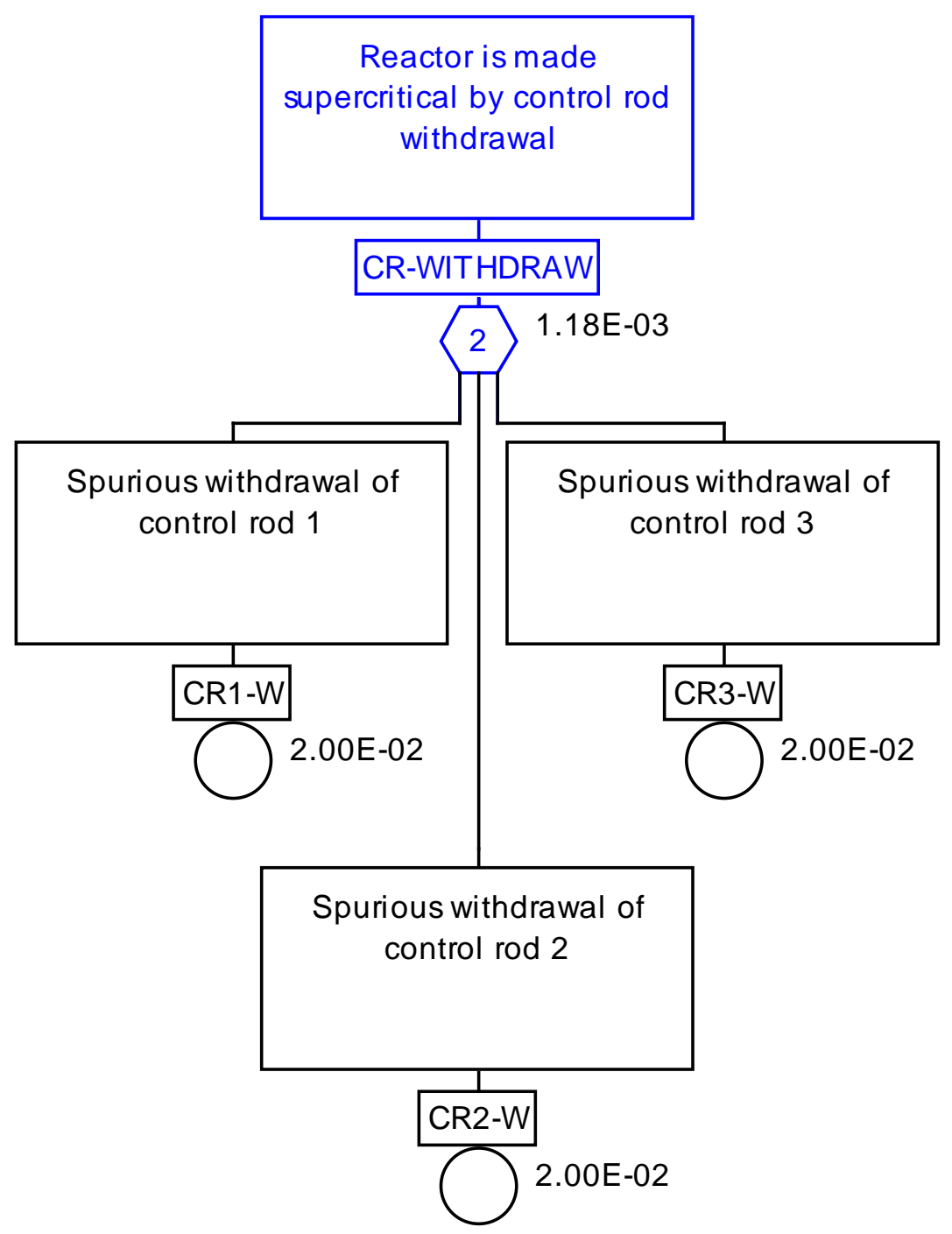

Figure A-4. Fault tree for uncontrolled control rod withdrawal. 


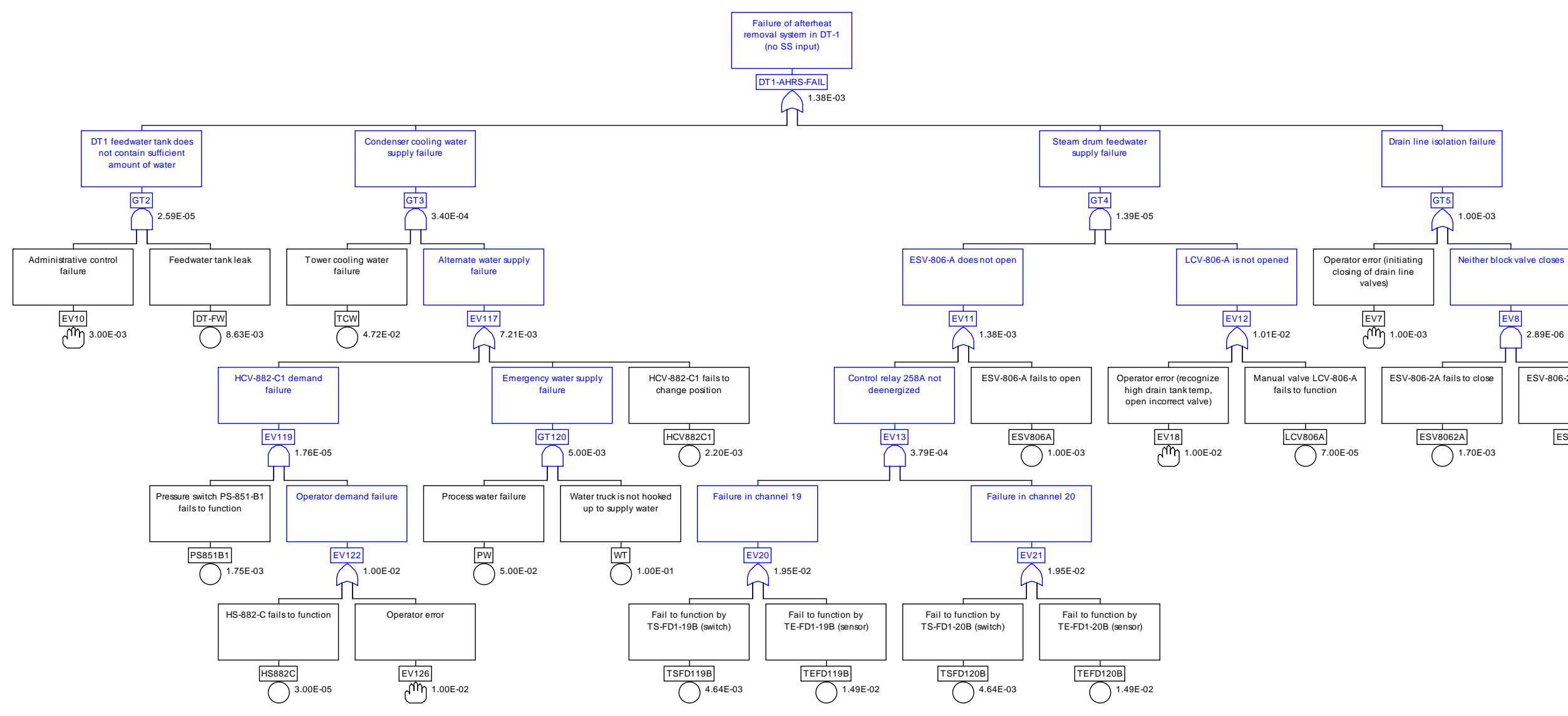

Figure A-5. Fault tree for failure of afterheat removal system in Drain Tank No. 1. 


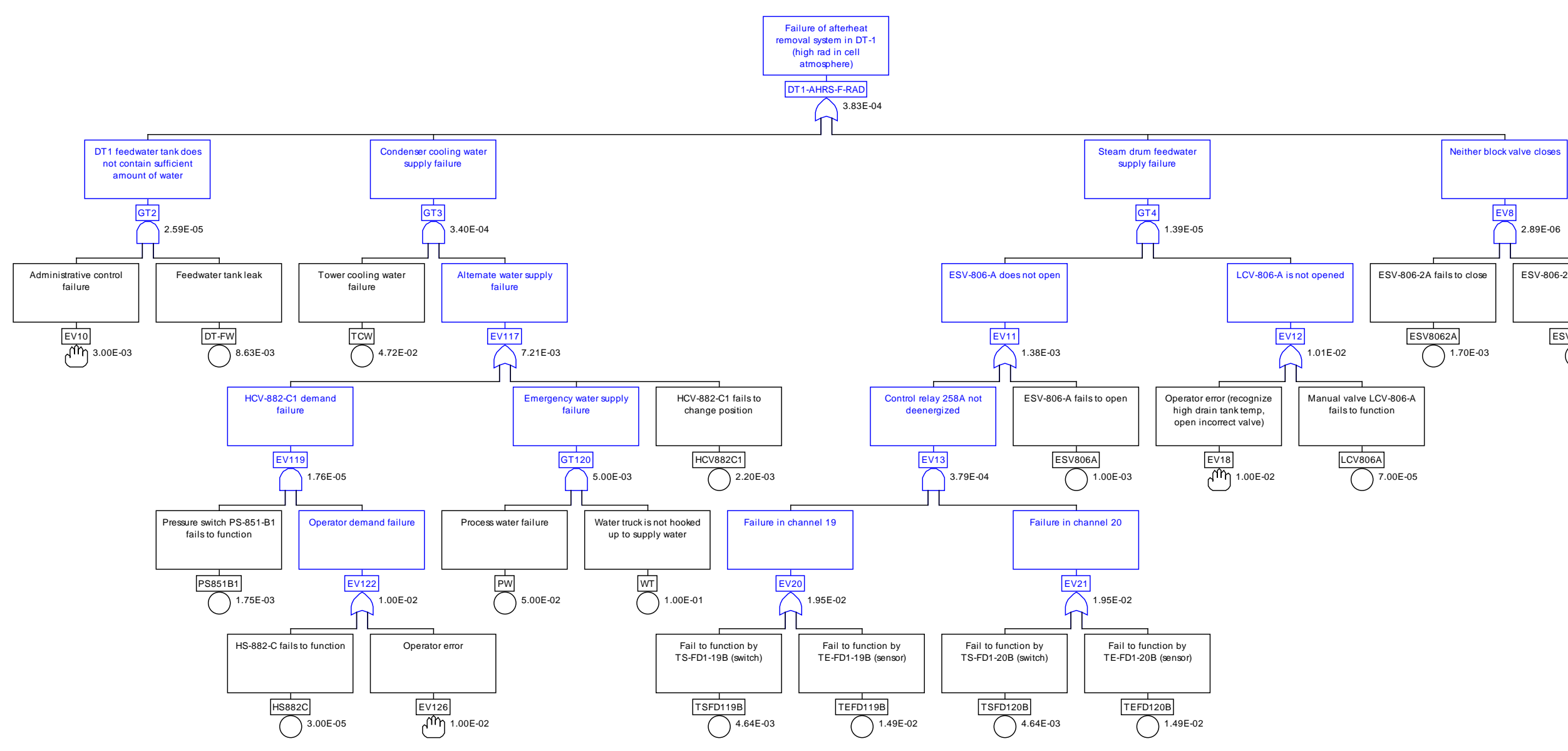

Figure A-6. Fault tree for failure of afterheat removal system in Drain Tank No. 1 in the case of high radiation levels in the cell atmosphere. 


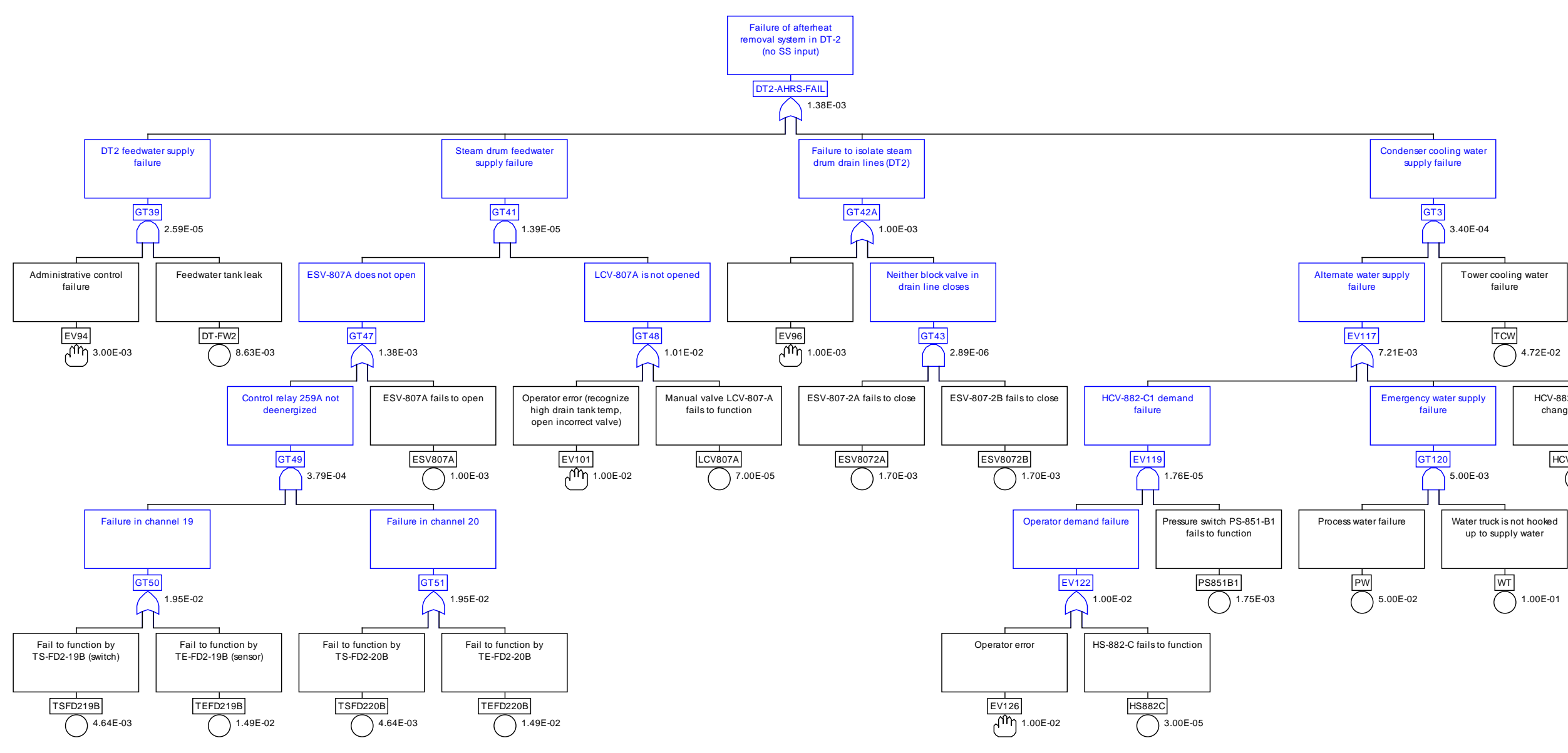

Figure A-7. Fault tree for failure of afterheat removal system in Drain Tank No. 2. 


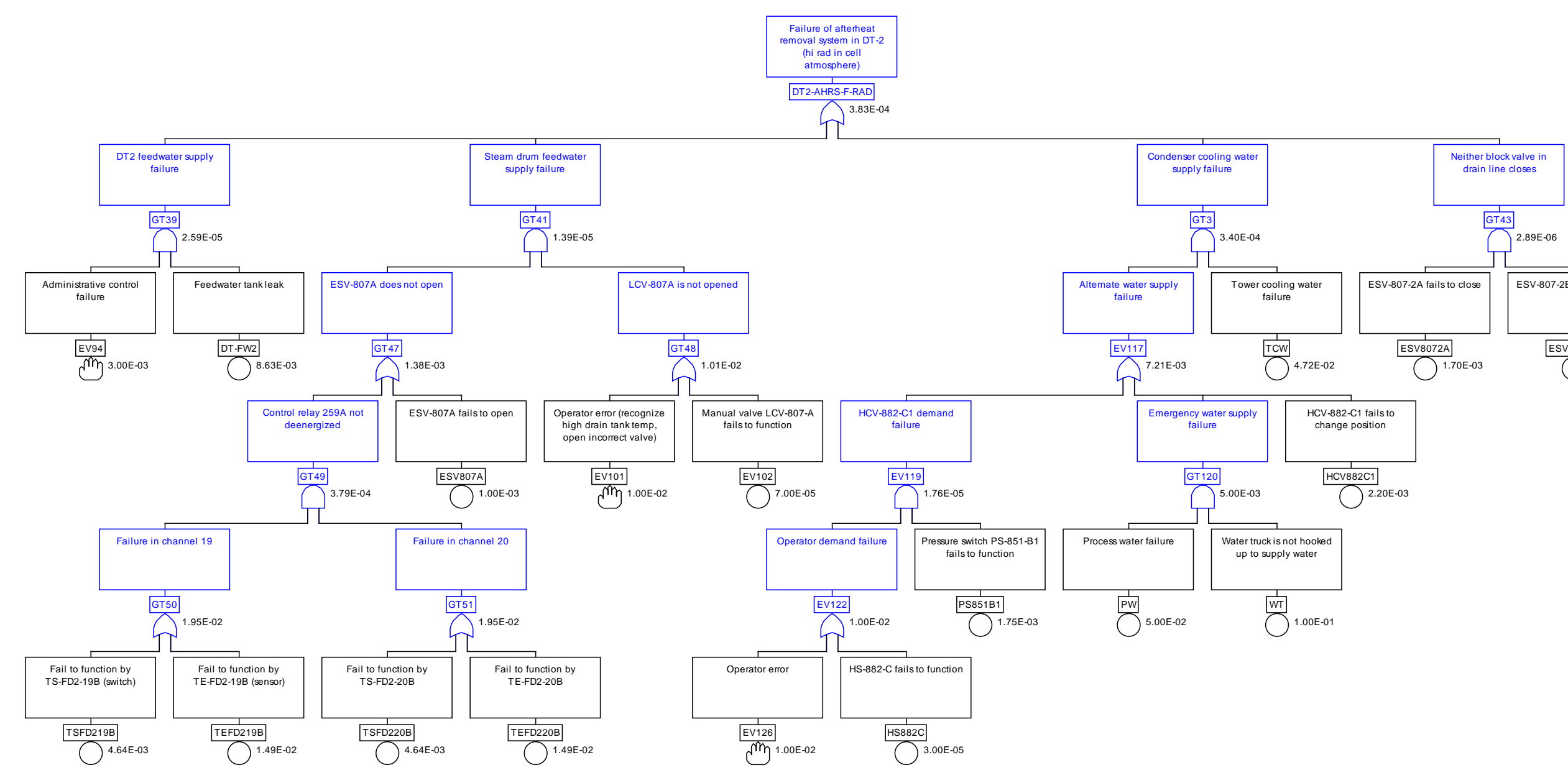

Figure A-8. Fault tree for failure of afterheat removal system in Drain Tank No. 2 in the case of high radiation levels in the cell atmosphere. 


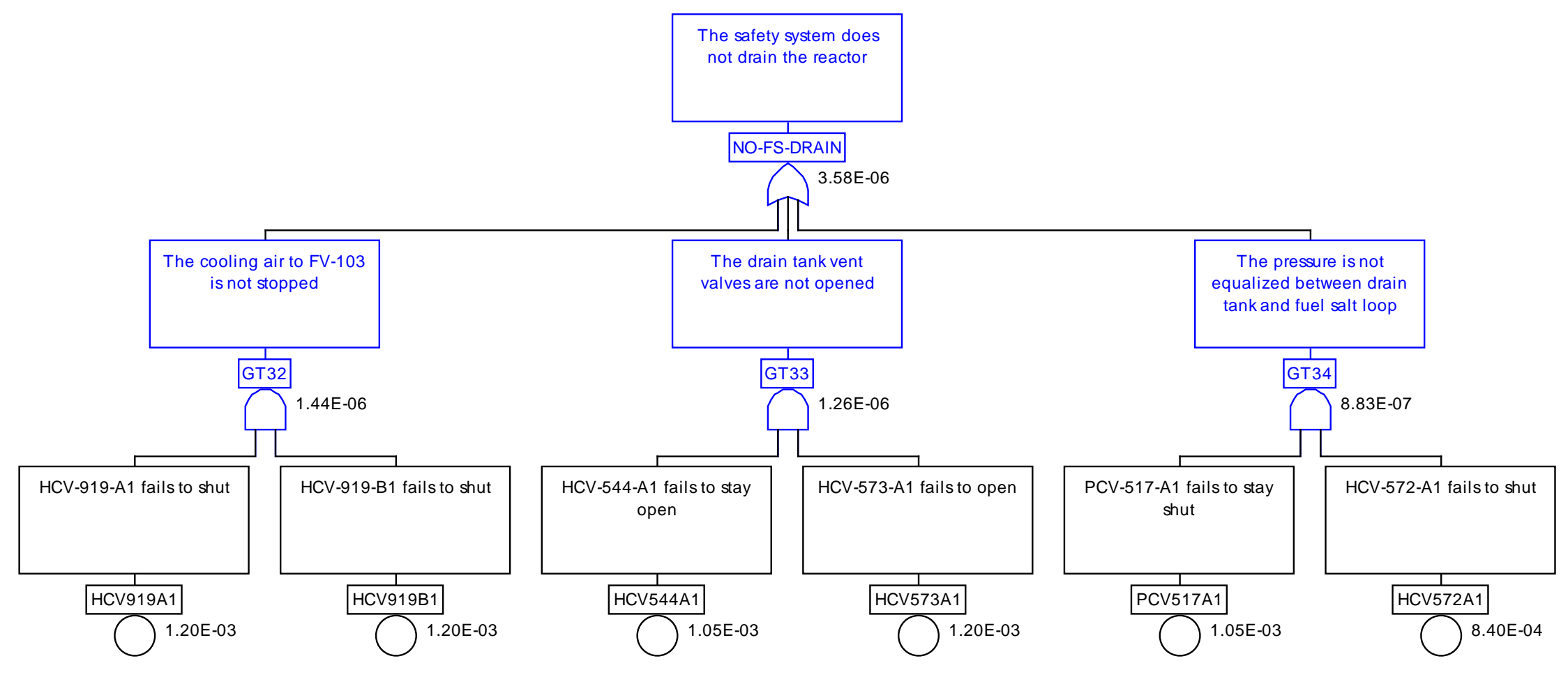

Figure A-9. Fault tree for failure to drain reactor. 


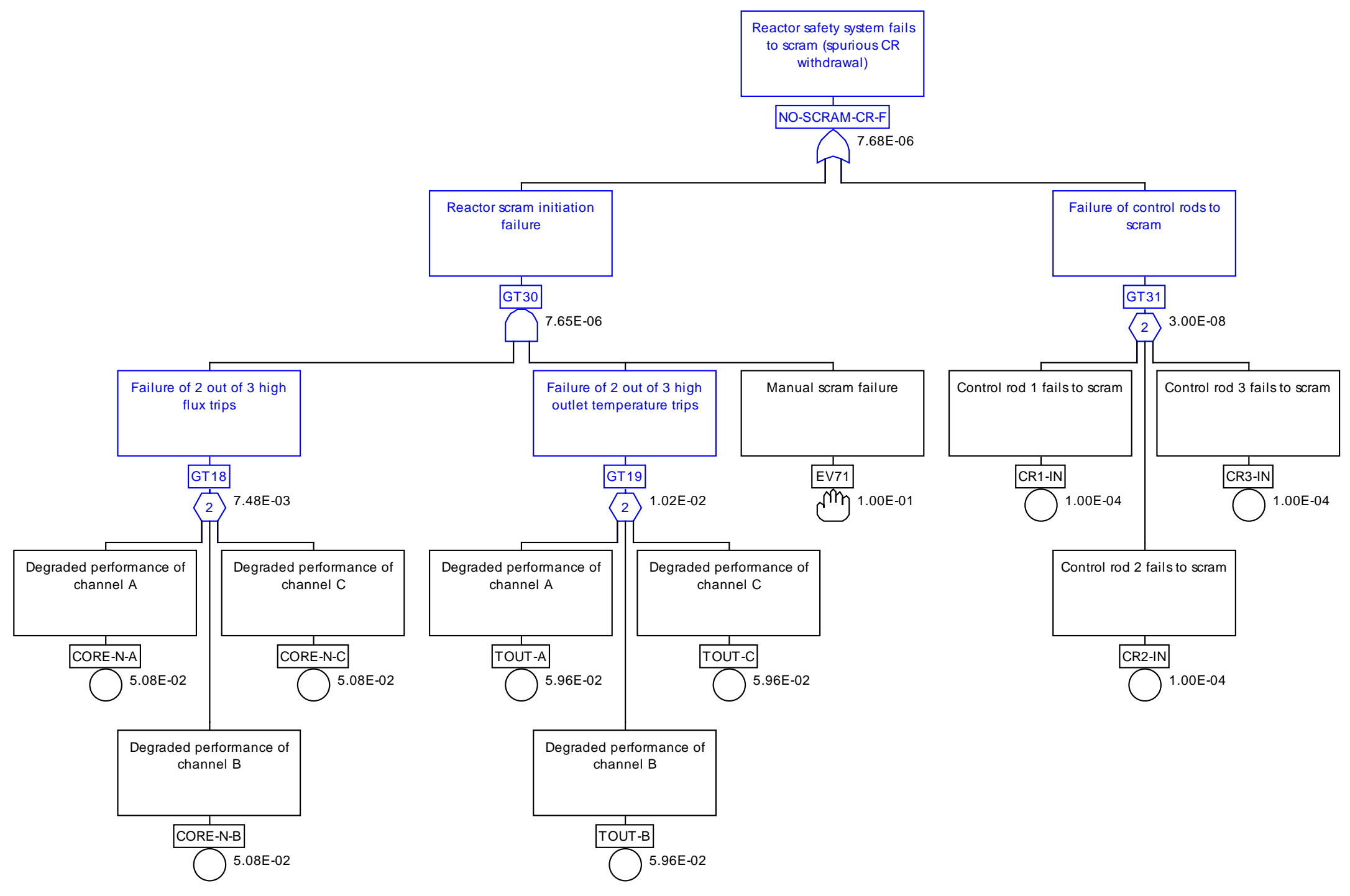

Figure A-10. Fault tree for failure to scram reactor. 


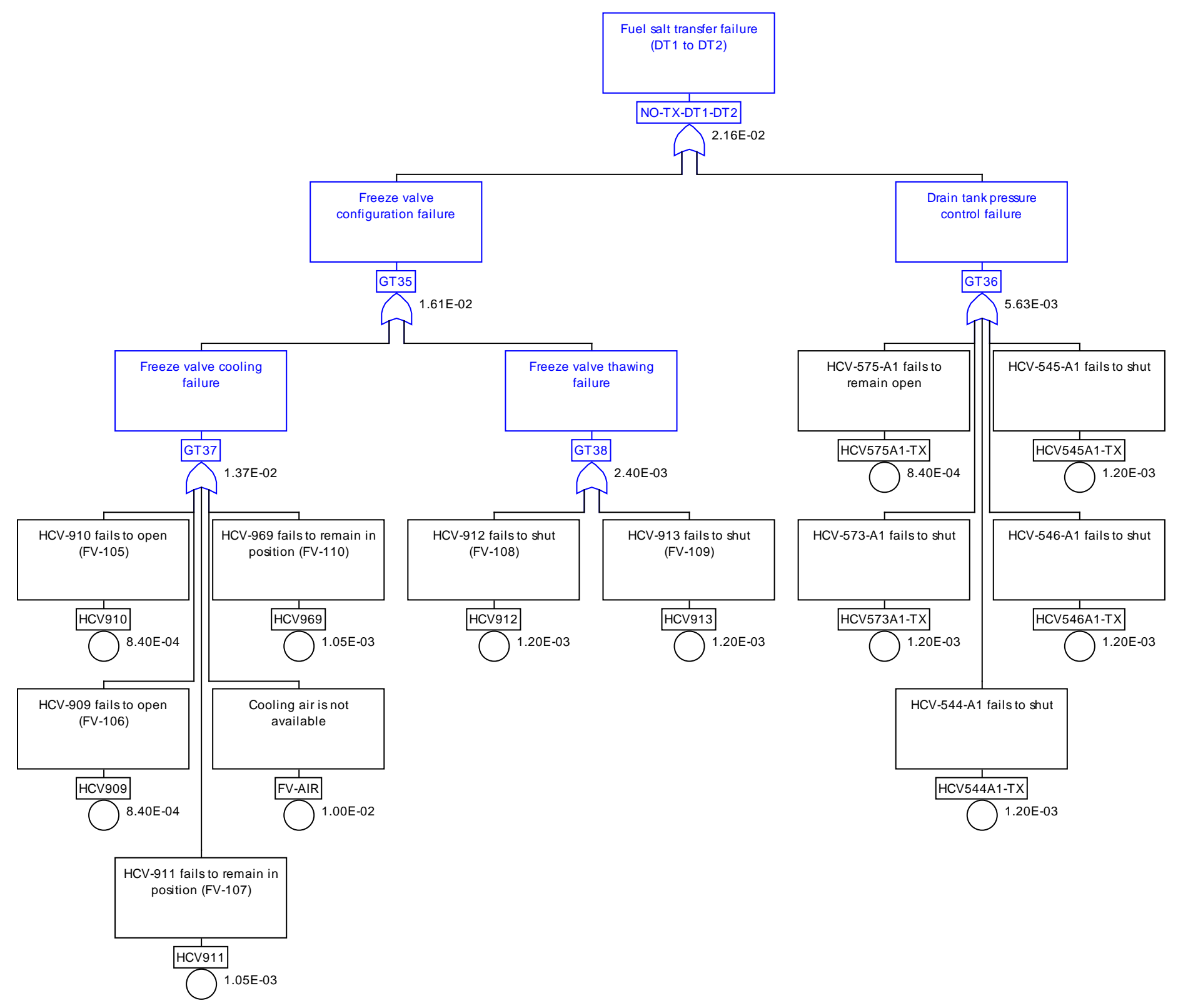

Figure A-11. Fault tree for failure to transfer fuel salt between drain tanks. 


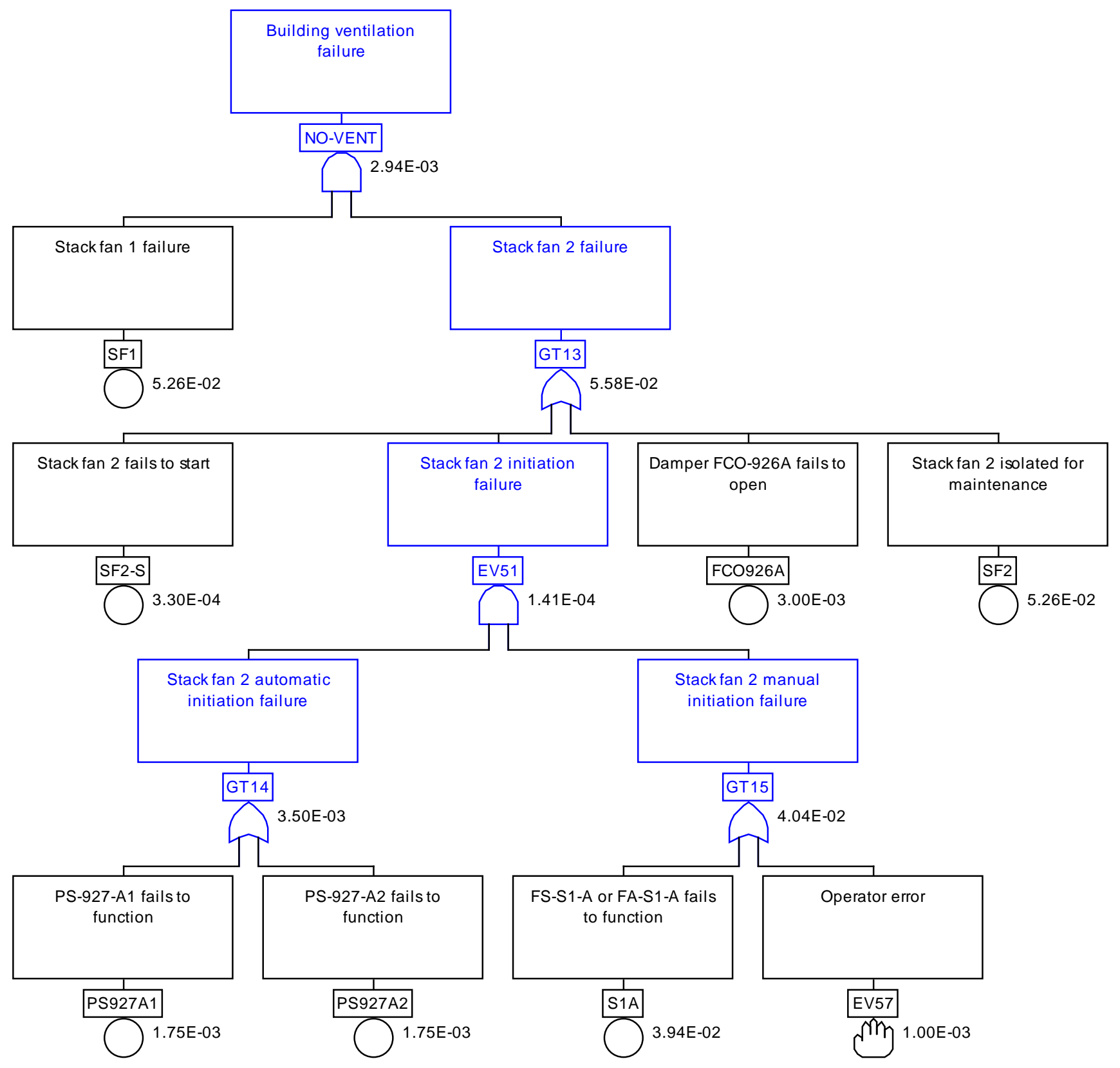

Figure A-12. Fault tree for failure of building ventilation system. 


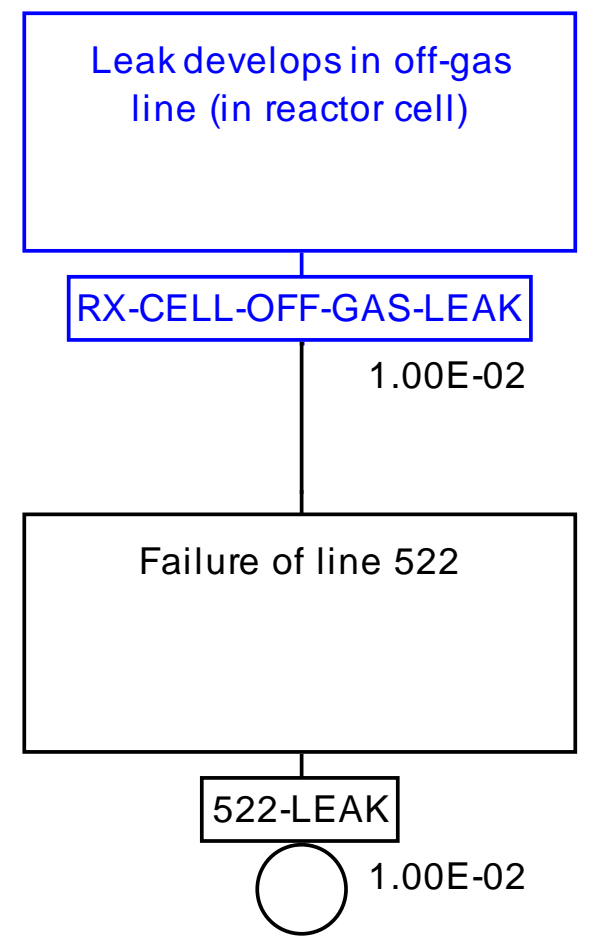

Figure A-13. Fault tree for failure of off-gas holdup piping 
APPENDIX B. FAILURE RATE DATABASE 


\section{APPENDIX B. FAILURE RATE DATABASE}

The following tables contain the failure rates used for basic events in the FTA of the MSRE, as well as the source from which the data were obtained.

Table B-1. Equipment reliability data used in MSRE FTA

\begin{tabular}{|c|c|c|c|c|c|c|}
\hline $\begin{array}{c}\text { Component } \\
\text { number }\end{array}$ & $\begin{array}{c}\text { Failure } \\
\text { rate }\end{array}$ & Units & Per Yr & $\begin{array}{c}\text { Source } \\
\text { (Report) }\end{array}$ & $\begin{array}{c}\text { Source } \\
\text { Identifier }\end{array}$ & Comments \\
\hline CCP-1 & 2.50E-06 & $\mathrm{hr}$ & 2.19E-02 & [1] & QBFAE & all failure modes of blower fan \\
\hline CCP-1-GOP & $1.30 \mathrm{E}-05$ & $\mathrm{hr}$ & 1.14E-01 & [1] & MPBAF & $\begin{array}{l}\text { all failure modes of motor } \\
\text { generator main lube oil pump } \\
\text { motor }\end{array}$ \\
\hline CCP-2 (start) & 2.08E-04 & d & $\mathrm{n} / \mathrm{a}$ & {$[2]$} & 3.3.4.c & $\begin{array}{l}\text { motor-driven fan fails to start on } \\
\text { demand }\end{array}$ \\
\hline ССР-2 & $2.50 \mathrm{E}-06$ & $\mathrm{hr}$ & 2.19E-02 & [1] & QBFAE & all failure modes of blower fan \\
\hline CCP-2-GOP & $1.30 \mathrm{E}-05$ & $\mathrm{hr}$ & 1.14E-01 & [1] & MPBAF & $\begin{array}{l}\text { all failure modes of motor } \\
\text { generator main lube oil pump } \\
\text { motor }\end{array}$ \\
\hline ANN & 7.70E-07 & $\mathrm{hr}$ & 6.75E-03 & [2] & 2.2 .2 & $\begin{array}{l}\text { catastrophic failure of an } \\
\text { annunciator }\end{array}$ \\
\hline DT-1-FW (leak) & 9.85E-07 & $\mathrm{hr}$ & 8.63E-03 & [2] & 3.6.1.1 & $\begin{array}{l}\text { catastrophic failure of an } \\
\text { atmospheric metallic vessel }\end{array}$ \\
\hline TS-FD1-20B & 5.30E-07 & $\mathrm{hr}$ & 4.64E-03 & [1] & STAFF & $\begin{array}{l}\text { fail to function by temperature } \\
\text { switch }\end{array}$ \\
\hline TS-FD1-19B & $5.30 \mathrm{E}-07$ & $\mathrm{hr}$ & 4.64E-03 & [1] & STAFF & $\begin{array}{l}\text { fail to function by temperature } \\
\text { switch }\end{array}$ \\
\hline TE-FD1-20B & 1.70E-06 & $\mathrm{hr}$ & 1.49E-02 & [1] & ATAFM & $\begin{array}{l}\text { fail to function by general } \\
\text { temperature sensor }\end{array}$ \\
\hline TE-FD1-19B & $1.70 \mathrm{E}-06$ & $\mathrm{hr}$ & 1.49E-02 & [1] & ATAFM & $\begin{array}{l}\text { fail to function by general } \\
\text { temperature sensor }\end{array}$ \\
\hline ESV-806A & $1.00 \mathrm{E}-03$ & d & $\mathrm{n} / \mathrm{a}$ & [1] & $\mathrm{VDOOH}$ & fail to open by solenoid valve \\
\hline LCV-806A & $7.00 \mathrm{E}-05$ & d & $\mathrm{n} / \mathrm{a}$ & [1] & VXPCE & $\begin{array}{l}\text { fail to change position by general } \\
\text { manual valve }\end{array}$ \\
\hline ESV-806-2A & $1.70 \mathrm{E}-03$ & d & $\mathrm{n} / \mathrm{a}$ & [1] & VDOEH & fail to close by solenoid valve \\
\hline ESV-806-2B & $1.70 \mathrm{E}-03$ & d & $\mathrm{n} / \mathrm{a}$ & [1] & VDOEH & fail to close by solenoid valve \\
\hline PS-851-B1 & $2.00 \mathrm{E}-07$ & $\mathrm{hr}$ & $1.75 \mathrm{E}-03$ & [1] & SPAFB & fail to function by pressure switch \\
\hline HCV-882-C1 & 2.20E-03 & $\mathrm{d}$ & $\mathrm{n} / \mathrm{a}$ & [2] & 3.5.3.3 & $\begin{array}{l}\text { no change of position on demand } \\
\text { by pneumatic operated valve }\end{array}$ \\
\hline
\end{tabular}


Table B-1. Equipment reliability data used in MSRE FTA (continued)

\begin{tabular}{|c|c|c|c|c|c|c|}
\hline $\begin{array}{c}\text { Component } \\
\text { number }\end{array}$ & $\begin{array}{c}\text { Failure } \\
\text { rate }\end{array}$ & Units & Per Yr & $\begin{array}{l}\text { Source } \\
\text { (Report) }\end{array}$ & $\begin{array}{c}\text { Source } \\
\text { Identifier }\end{array}$ & Comments \\
\hline HCV-565-A1 & $2.20 \mathrm{E}-03$ & $\mathrm{~d}$ & $\mathrm{n} / \mathrm{a}$ & [2] & 3.5.3.3 & $\begin{array}{l}\text { no change of position on demand } \\
\text { by pneumatic operated valve }\end{array}$ \\
\hline RM-565B & $6.00 \mathrm{E}-06$ & $\mathrm{hr}$ & $5.26 \mathrm{E}-02$ & [1] & ARBFM & $\begin{array}{l}\text { fail to function by radiation } \\
\text { monitors (BWR main steam line) }\end{array}$ \\
\hline RM-565C & $6.00 \mathrm{E}-06$ & $\mathrm{hr}$ & $5.26 \mathrm{E}-02$ & [1] & ARBFM & $\begin{array}{l}\text { fail to function by radiation } \\
\text { monitors (BWR main steam line) }\end{array}$ \\
\hline RSS-365B1 & $5.30 \mathrm{E}-07$ & $\mathrm{hr}$ & 4.64E-03 & [1] & STAFF & $\begin{array}{l}\text { fail to function by temperature } \\
\text { switch }\end{array}$ \\
\hline RSS-365C1 & $5.30 \mathrm{E}-07$ & $\mathrm{hr}$ & 4.64E-03 & [1] & STAFF & $\begin{array}{l}\text { fail to function by temperature } \\
\text { switch }\end{array}$ \\
\hline Stack fan 1 & $6.00 \mathrm{E}-06$ & $\mathrm{hr}$ & 5.26E-02 & [1] & QFVRH & $\begin{array}{l}\text { fail to run by containment } \\
\text { ventilation fan }\end{array}$ \\
\hline Stack fan 2 (run) & $6.00 \mathrm{E}-06$ & $\mathrm{hr}$ & $5.26 \mathrm{E}-02$ & [1] & QFVRH & $\begin{array}{l}\text { fail to run by containment } \\
\text { ventilation fan }\end{array}$ \\
\hline Stack fan 2 (start) & $3.30 \mathrm{E}-04$ & $\mathrm{~d}$ & $\mathrm{n} / \mathrm{a}$ & [1] & QFVSH & $\begin{array}{l}\text { fail to start by containment } \\
\text { ventilation fan }\end{array}$ \\
\hline PS-927-A1 & $2.00 \mathrm{E}-07$ & $\mathrm{hr}$ & $1.75 \mathrm{E}-03$ & [1] & SPAFB & fail to function by pressure switch \\
\hline PS-927-A2 & $2.00 \mathrm{E}-07$ & hr & 1.75E-03 & [1] & SPAFB & fail to function by pressure switch \\
\hline FCO-926A & 3.00E-03 & $\mathrm{d}$ & $\mathrm{n} / \mathrm{a}$ & [1] & QDAFI & fail to function by damper \\
\hline FS/FA-S1-A & 4.50E-06 & $\mathrm{hr}$ & $3.94 \mathrm{E}-02$ & [1] & ICFFM & $\begin{array}{l}\text { fail to function by analog flow } \\
\text { channel }\end{array}$ \\
\hline $\begin{array}{l}\text { Control Rods } \\
\text { (withdrawal) }\end{array}$ & 2.00E-02 & $\mathrm{yr}$ & $\mathrm{n} / \mathrm{a}$ & [3] & 7.3.6.1 & spurious control rod withdrawal \\
\hline $\begin{array}{l}\text { Control Rods } \\
\text { (insert) }\end{array}$ & $1.00 \mathrm{E}-04$ & d & $\mathrm{n} / \mathrm{a}$ & [1] & OCR2W & fail to insert by control rod \\
\hline Core flux channels & $5.80 \mathrm{E}-06$ & $\mathrm{hr}$ & $5.08 \mathrm{E}-02$ & [1] & ICCBM & $\begin{array}{l}\text { degraded performance by core } \\
\text { analog flux channel }\end{array}$ \\
\hline $\begin{array}{l}\text { Core outlet temp } \\
\text { channels }\end{array}$ & $6.80 \mathrm{E}-06$ & hr & 5.96E-02 & [1] & ICTBM & $\begin{array}{l}\text { degraded performance by analog } \\
\text { temperature channel }\end{array}$ \\
\hline HCV-919A1 & $1.20 \mathrm{E}-03$ & $\mathrm{~d}$ & $\mathrm{n} / \mathrm{a}$ & [1] & VAAEH & fail to close by air operated valve \\
\hline HCV-919B1 & $1.20 \mathrm{E}-03$ & d & $\mathrm{n} / \mathrm{a}$ & [1] & VAAEH & fail to close by air operated valve \\
\hline
\end{tabular}


Table B-1. Equipment reliability data used in MSRE FTA (continued)

\begin{tabular}{|c|c|c|c|c|c|c|}
\hline $\begin{array}{c}\text { Component } \\
\text { number }\end{array}$ & $\begin{array}{c}\text { Failure } \\
\text { rate }\end{array}$ & Units & Per Yr & $\begin{array}{l}\text { Source } \\
\text { (Report) }\end{array}$ & $\begin{array}{c}\text { Source } \\
\text { Identifier }\end{array}$ & Comments \\
\hline HCV-544-A1 & $1.20 \mathrm{E}-07$ & $\mathrm{hr}$ & 1.05E-03 & [1] & VARDH & $\begin{array}{l}\text { fail to remain in position by air } \\
\text { operated valve }\end{array}$ \\
\hline HCV-573-A1 & $1.20 \mathrm{E}-03$ & d & $\mathrm{n} / \mathrm{a}$ & [1] & VAAEH & $\begin{array}{l}\text { fail to close by air operated } \\
\text { valve }\end{array}$ \\
\hline PCV-517-A1 & $1.20 \mathrm{E}-07$ & $\mathrm{hr}$ & $1.05 \mathrm{E}-03$ & [1] & VARDH & $\begin{array}{l}\text { fail to remain in position by air } \\
\text { operated valve }\end{array}$ \\
\hline HCV-572-A1 & 8.40E-04 & $\mathrm{d}$ & $\mathrm{n} / \mathrm{a}$ & [1] & VAAOH & $\begin{array}{l}\text { fail to open by air operated } \\
\text { valve }\end{array}$ \\
\hline $\begin{array}{l}\text { HCV-573-A1 } \\
\text { (transfer) }\end{array}$ & $1.20 \mathrm{E}-03$ & d & $\mathrm{n} / \mathrm{a}$ & [1] & VAAEH & $\begin{array}{l}\text { fail to close by air operated } \\
\text { valve }\end{array}$ \\
\hline $\begin{array}{l}\text { HCV-544-A1 } \\
\text { (transfer) }\end{array}$ & $1.20 \mathrm{E}-03$ & $\mathrm{~d}$ & $\mathrm{n} / \mathrm{a}$ & [1] & VAAEH & $\begin{array}{l}\text { fail to close by air operated } \\
\text { valve }\end{array}$ \\
\hline HCV-575-A1 & 8.40E-04 & $\mathrm{d}$ & $\mathrm{n} / \mathrm{a}$ & [1] & VAAOH & $\begin{array}{l}\text { fail to open by air operated } \\
\text { valve }\end{array}$ \\
\hline HCV-545-A1 & $1.20 \mathrm{E}-03$ & $\mathrm{~d}$ & $\mathrm{n} / \mathrm{a}$ & [1] & VAAEH & $\begin{array}{l}\text { fail to close by air operated } \\
\text { valve }\end{array}$ \\
\hline HCV-546-A1 & 1.20E-03 & $\mathrm{d}$ & n/a & [1] & VAAEH & $\begin{array}{l}\text { fail to close by air operated } \\
\text { valve }\end{array}$ \\
\hline $\begin{array}{l}\text { Cooling Air } \\
\text { (transfer) }\end{array}$ & $1.00 \mathrm{E}-02$ & $\mathrm{yr}$ & $\mathrm{n} / \mathrm{a}$ & Assumption & $\begin{array}{l}\text { NO- } \\
\text { COOL- } \\
\text { AIR }\end{array}$ & order of magnitude estimate \\
\hline HCV-910 (FV-105) & 8.40E-04 & $\mathrm{d}$ & n/a & [1] & VAAOH & $\begin{array}{l}\text { fail to open by air operated } \\
\text { valve }\end{array}$ \\
\hline HCV-909 (FV-106) & $8.40 \mathrm{E}-04$ & d & $\mathrm{n} / \mathrm{a}$ & [1] & VAAOH & $\begin{array}{l}\text { fail to open by air operated } \\
\text { valve }\end{array}$ \\
\hline HCV-911 (FV-107) & $1.20 \mathrm{E}-07$ & $\mathrm{hr}$ & 1.05E-03 & [1] & VARDH & $\begin{array}{l}\text { fail to remain in position by air } \\
\text { operated valve }\end{array}$ \\
\hline HCV-969 (FV-110) & $1.20 \mathrm{E}-07$ & $\mathrm{hr}$ & $1.05 \mathrm{E}-03$ & [1] & VARDH & $\begin{array}{l}\text { fail to remain in position by air } \\
\text { operated valve }\end{array}$ \\
\hline HCV-912 (FV-108) & $1.20 \mathrm{E}-03$ & $\mathrm{~d}$ & $\mathrm{n} / \mathrm{a}$ & [1] & VAAEH & $\begin{array}{l}\text { fail to close by air operated } \\
\text { valve }\end{array}$ \\
\hline HCV-913 (FV-109) & $1.20 \mathrm{E}-03$ & d & n/a & {$[1]$} & VAAEH & $\begin{array}{l}\text { fail to close by air operated } \\
\text { valve }\end{array}$ \\
\hline TS-FD2-20B & 5.30E-07 & $\mathrm{hr}$ & 4.64E-03 & [1] & STAFF & $\begin{array}{l}\text { fail to function by temperature } \\
\text { switch }\end{array}$ \\
\hline TS-FD2-19B & $5.30 \mathrm{E}-07$ & $\mathrm{hr}$ & 4.64E-03 & [1] & STAFF & $\begin{array}{l}\text { fail to function by temperature } \\
\text { switch }\end{array}$ \\
\hline TE-FD2-20B & 1.70E-06 & $\mathrm{hr}$ & 1.49E-02 & [1] & ATAFM & $\begin{array}{l}\text { fail to function by general } \\
\text { temperature sensor }\end{array}$ \\
\hline TE-FD2-19B & $1.70 \mathrm{E}-06$ & $\mathrm{hr}$ & 1.49E-02 & [1] & ATAFM & $\begin{array}{l}\text { fail to function by general } \\
\text { temperature sensor }\end{array}$ \\
\hline ESV-807A & $1.00 \mathrm{E}-03$ & $\mathrm{~d}$ & $\mathrm{n} / \mathrm{a}$ & {$[1]$} & VDOOH & fail to open by solenoid valve \\
\hline LCV-807A & 4.70E-06 & $\mathrm{hr}$ & 4.12E-02 & {$[1]$} & VXACG & $\begin{array}{l}\text { fail to change position by } \\
\text { general manual valve }\end{array}$ \\
\hline ESV-807-2A & $1.70 \mathrm{E}-03$ & $\mathrm{~d}$ & $\mathrm{n} / \mathrm{a}$ & {$[1]$} & VDOEH & fail to close by solenoid valve \\
\hline ESV-807-2B & $1.70 \mathrm{E}-03$ & $\mathrm{~d}$ & $\mathrm{n} / \mathrm{a}$ & [1] & VDOEH & fail to close by solenoid valve \\
\hline
\end{tabular}


Table B-1. Equipment reliability data used in MSRE FTA (continued)

\begin{tabular}{|c|c|c|c|c|c|c|}
\hline $\begin{array}{c}\text { Component } \\
\text { number }\end{array}$ & $\begin{array}{c}\text { Failure } \\
\text { rate }\end{array}$ & Units & Per Yr & $\begin{array}{l}\text { Source } \\
\text { (Report) }\end{array}$ & $\begin{array}{c}\text { Source } \\
\text { Identifier }\end{array}$ & Comments \\
\hline DT-1-FW (leak) & $9.85 \mathrm{E}-07$ & $\mathrm{hr}$ & 8.63E-03 & [2] & 3.6.1.1 & $\begin{array}{l}\text { catastrophic failure of an } \\
\text { atmospheric metallic vessel }\end{array}$ \\
\hline DT-2-FW (leak) & $9.85 \mathrm{E}-07$ & $\mathrm{hr}$ & 8.63E-03 & [2] & 3.6.1.1 & $\begin{array}{l}\text { catastrophic failure of an } \\
\text { atmospheric metallic vessel }\end{array}$ \\
\hline $\begin{array}{l}\text { Off-gas piping (Line } \\
522)^{*}\end{array}$ & 2.68E-08 & $\begin{array}{l}\text { Mile- } \\
\mathrm{hr}\end{array}$ & 4.45E-6 & [2] & 3.2.1.1 & $\begin{array}{l}\text { catastrophic failure of straight } \\
\text { section of metal piping, } 100 \mathrm{ft} \\
\text { length assumed }\end{array}$ \\
\hline $\begin{array}{l}\text { Off-gas disconnect } \\
\text { flange (Line 522)* }\end{array}$ & $5.70 \mathrm{E}-07$ & $\mathrm{hr}$ & 4.99E-03 & [2] & 3.2.1.4 & $\begin{array}{l}>10 \% \text { flow area failure of } \\
\text { metal piping connection }\end{array}$ \\
\hline $\begin{array}{l}\text { Tower cooling } \\
\text { water }\end{array}$ & 4.72E-02 & $\mathrm{yr}$ & $\mathrm{n} / \mathrm{a}$ & [4] & RCW & $\begin{array}{l}\text { yearly probability for RCW } \\
\text { failure }\end{array}$ \\
\hline Process water & $5.00 \mathrm{E}-02$ & $\mathrm{yr}$ & $\mathrm{n} / \mathrm{a}$ & [4] & RCS & $\begin{array}{l}\text { yearly probability for RSW } \\
\text { failure }\end{array}$ \\
\hline HS882C & $3.00 \mathrm{E}-05$ & d & $\mathrm{n} / \mathrm{a}$ & [1] & SMACI & $\begin{array}{l}\text { failure of general manual } \\
\text { switch to change position }\end{array}$ \\
\hline Water truck & $1.00 \mathrm{E}-01$ & d & $\mathrm{n} / \mathrm{a}$ & Assumption & WT & order of magnitude estimate? \\
\hline RE-S1-A/B/C & $6.00 \mathrm{E}-06$ & $\mathrm{hr}$ & $5.26 \mathrm{E}-02$ & [1] & ARBFM & $\begin{array}{l}\text { fail to function by radiation } \\
\text { monitors (BWR main steam } \\
\text { line) }\end{array}$ \\
\hline
\end{tabular}

*Note: The frequency for the IE of an off-gas leak in Line 522 (Figure A-13) was calculated by assuming a length of pipe 100 feet long with two disconnect flanges (i.e., $2 \times 4.99 \mathrm{E}-03+4.45 \mathrm{E}-6=9.98 \mathrm{E}-3$, or about $1 \mathrm{E}-2$ failures per year)

Table B-2. Human reliability data used in MSRE FTA

\begin{tabular}{|l|l|l|l|l|}
\hline \multicolumn{1}{|c|}{ Situation } & \multicolumn{1}{|c|}{$\begin{array}{c}\text { Failure } \\
\text { rate }\end{array}$} & \multicolumn{1}{|c|}{ Units } & $\begin{array}{c}\text { Source } \\
\text { report }\end{array}$ & \multicolumn{1}{|c|}{ Source identifier } \\
\hline Starting CCP-2 & $1.00 \mathrm{E}-03$ & $\mathrm{~d}$ & {$[5]$} & Table 11-13 \\
\hline Opening LCV-806A & $1.00 \mathrm{E}-02$ & $\mathrm{~d}$ & {$[5]$} & Table 20-13 (5) \\
\hline $\begin{array}{l}\text { Closing drain tank } \\
\text { afterheat removal } \\
\text { system drain valves }\end{array}$ & $1.00 \mathrm{E}-03$ & $\mathrm{~d}$ & {$[5]$} & $\mathrm{n} / \mathrm{a}$ \\
\hline $\begin{array}{l}\text { Checking feedwater } \\
\text { tank(s) }\end{array}$ & $3.00 \mathrm{E}-03$ & $\mathrm{~d}$ & {$[5]$} & Table 15-3 (2) \\
\hline Closing HCV-565-A1 & $1.00 \mathrm{E}-03$ & $\mathrm{~d}$ & {$[5]$} & Table 11-13 \\
\hline Starting stack fan No. 2 & $1.00 \mathrm{E}-03$ & $\mathrm{~d}$ & Assumption & n/a \\
\hline $\begin{array}{l}\text { SCRAM on CR } \\
\text { withdrawal }\end{array}$ & $1.00 \mathrm{E}-01$ & $\mathrm{~d}$ & Assumption & n/a \\
\hline Opening LCV-807A & $1.00 \mathrm{E}-02$ & $\mathrm{~d}$ & {$[5]$} & Table 20-13 (5) \\
\hline Initiate HCV-882-C1 & $1.00 \mathrm{E}-02$ & $\mathrm{~d}$ & {$[5]$} & Table 20-13 (5) \\
\hline
\end{tabular}





\section{APPENDIX A-B REFERENCES}

1. International Atomic Energy Agency (IAEA), “Component Reliability Data for Use in Probabilistic Safety Assessment,” IAEA, Vienna, 1988.

2. Center for Chemical Process Safety (CCPS), "Guidelines for Process Equipment Reliability Data with Data Tables,” CCPS, New York, NY, 1989.

3. US Department of Energy (DOE), "Probabilistic Risk Assessment for the Standard Modular High Temperature Gas-Cooled Reactor,” DOE-HTGR-86-011, Revision 3, Volume 1, January 1987.

4. S. Pistelli, "Dynamic approach to the reliability analysis for the Service Water System of a Candu 6 nuclear power plant," Proceedings of the 2011 3rd International Youth Conference on Energetics, IEEE, 2011.

5. US Nuclear Regulatory Commission (NRC), Handbook of Human Reliability Analysis with Emphasis on Nuclear Power Plant Applications,” NUREG/CR-1278, August 1983. 